\title{
1. Was the Passage on the Five Evils in the Larger Pure Land Sütra Composed in China?
}

NōNIn Masaaki

The "five evils" described in the Larger Pure Land Sütra are the same concept as the pañca-kașāya, translated as the "five corruptions." This reveals the following: the fundamental teaching of the passage on the five evils in the Chinese version of the Larger Sukha vatīvy ūha Sütra (Taisho No.362) is a doctrinal tradition common to a passage in the Sanskrit version of the Smaller Sukhāvatīvyūha Sütra that describes Sākyamuni Buddha's appearance and preaching in this world of the five corruptions. We can thus say that the description of the five evils, whose source is the five corruptions, has its origin in India. However, it is true that in this passage we find considerable vestiges of editorial changes that go beyond translation. We think, therefore, that the passage on the five evils consists of the translator's independent interpretation of the idea of the five corruptions, as well as of his technical expressions of Chinese origin.

\section{Ajātaśatru Described in the Vinaya}

Nagahara Tomoyuki

Ajātaśatru was an actual king of Magadha in ancient India, in the time of Gautama Buddha (B.C.5C). He usurped the throne from his father, Bimbisāra, attempting to kill him. Ajātaśatru carried out a coup d'état.

It is stated in the Mahāyāna Mahāparinivāna Sütra that one cannot die a gentle and easy death as a Buddhist if one committed parricide, one of the five great mortal sins. Ajātaśatru represents anyone who is distressed by parricide and has remorse for his sin. Salvation from torment is one of the major subjects of Pure Land Buddhism.

I study Ajātaśatru from the viewpoint of Pure Land Buddhism.

In the process, I came to be interested in how Ajātaśatru was described in some other sutras and documents.

Here, I would like to pay attention to the Vinaya, which includes the story of Ajātaśatru, and give some views according to the following small subjects.

1. The meaning of Ajātaśatru.

2. The relationship between Ajātaśatru and Devadatta. 
3. Ajātaśatru's dependence on Devadatta. (Devadatta won Ajātaśatru's favor by giving an inspired performance.)

4. Attempted patricide.

5. How Bimbisāra was confined.

6. Bimbisāra's abdication from the throne and his suicide.

7. Ajātaśatru's son.

8. And others.

In the Vinaya I find a quite different image of Ajātaśatru from that in the Mahāyāna $M a$ hāparinivāna Sütra.

\section{The Emergence of Terms Related to the Concept of the Cakravartin in Stone In- scriptions From the Northern Dynasties Period}

KuRAMOTo Shōtoku

In the Buddhist tradition, the cakravartin is an idealized monarch who governs the world in accordance with the Dharma. He is endowed with the cakraratna, or "wheel-treasure" (often conceived of as a wheel made of gold), bestowed upon him by heaven and which he turns in order to conquer and rule the world.

One of the primary questions about the role played by this concept in Chinese history concerns the manner in which different Chinese emperors adopted the image of the cakravartin, and modified it to suit their particular needs.

As prior research has shown, it is clear that both Liang Wu di (梁武帝) and Sui Wen di (隋文帝) were construed as cakravartins. Up to now, however, there have not been any studies of whether terms related to the concept of the cakravartin are also encountered in materials dating to the Northern Dynasties Period prior to the Sui Dynasty.

The present paper introduces a number of Buddhist inscriptions bearing era names of the Northern Dynasties Period in order to demonstrate the existence of inscriptions lauding emperors as cakravartins, or expressing a yearning for the emergence of a golden wheel. 


\section{On the Dasheng wumen shixiang lun: A Commentary on the Mahā-samnipāta-sūtra by the Dilun School in a Dunhuang Manuscript}

IsHII Kōsei

No commentary on the Mahā-samnipāta-sūtra 大集経 exists. The only exception is the Dasheng Wumen shixiang lun 大乗五門実相論 (N8738) found among the Dunhuang 敦 煌 manuscripts. Based on the style of writing, it can be recognized as a work from before the Tang 唐 Dynasty. It shows influence of the Daśabhümikavyākhyāna 十地経論 and the usage of Dilun terminology proves that the text is from the Dilun school 地論宗.

This commentary emphasizes that fajie tixing 法界体性 is free from opposing elements such as being and no-being. The practice of dhāranī is also stressed because dhāranīis are based on the dharma-dhātu itself. The pioneering elements of the Chan School can also be seen here.

\section{A Study of the Lüelun Anle Jingduyi 略論安楽浄士義}

TANı Hidetoshi

There have been serious arguments about the author of the Lüelun Anle Jingduyi. There was an opinion that it is Tanluan's work as are "The Hymns to Amida Buddha" and "The Commentary on Vasubandhu's Discourse on The Pure Land." Other opinions are that it is Kumārajiva's work, or due to one of Shandao's disciples. It is even said that it was written in Japan.

Since written copies of Lüelun Anle Jingduyi and "The Hymns to Amida Buddha" were found together in Dunhuang, the opinion that it is the work of Tanluan found support.

However, these written copies were done about 170 years after Tanluan's death. So that it cannot be completely proved that the work is Tanluan's.

Moreover, if we compare the contents of the Lüelun Anle Jingduyi with "The Commentary on Vasubandhu's Discourse on The Pure Land," we see both similarities and differences between them. Therefore, it is still ucnlear whether it's Tanluan's work.

In this paper, I explore whether at this stage it is possible to conclude that the Lüelun Anle Jingduyi was indeed authored by Tanluan, and conclude that it is not yet possible to say. 


\section{Seeing the Buddha in Shandao's Guanjing $S h u$}

OKAZAKı Hidemaro

Seeing the Buddha is preached systematically in the Guan wuliangshuo jing. Vaidehi's seeing the Buddha is considered to be an indispensable element for Birth in Pure Land in the Guan wuliangshuo jing. Therefore, Shandao considers seeing the Buddha how you arrest him. The center of the consideration is difference in "Kezakan (華座観)" and "Kodai Gengoku (光台現国)" for Seeing the Buddha. And I pointed out that it was found the difference whether there was a voluntary outcome of "Amida Buddha" not "Gautama Buddha." The appearance is shown figuratively as “Kucyujyuryu (空中住立).”

\section{Self-Power and Other-Power in the Anle ji}

SugiYama Hirotoshi

The work Anle ji by Daochuo has many quotes from Tanluan's collected works.

It seems that Daochuo was greatly influenced by the ideas of Tanluan.

However, a reading of "self-power and other-power" in the Anle ji, suggests that it differs from Tanluan's ideas.

Therefore, setting aside late interpretations of the Anle ji, I focus on "self-power and other-power."

First, I compare the background of how Daochuo developed an argument on "self-power and other-power" in his own way without following the opinion of Tanluan, the master of Daochuo.

Second, I reveal the difference in their understandings of "self-power and other-power" through a comparison with Tanluan's Wangsheng Lunzhu.

\section{The Genealogy of the Nianfo sanmei baowang lun 念仏三昧宝王論}

Katō Hirotaka

There exist several versions among the codex and xylographs of the Nianfo sanmei baowang lun 念仏三昧宝王論 written by Feixi 飛錫 in the Mid-Tang Dynasty 唐代中期.

The genealogy of these versions is still unclear. Therefore, we have to investigate the 
historical background of the production of each codex and xylograph.

It is essential not only to deal with the colophons of each version, but also to survey the transmission of this work. We have to pay attention especially to the transmission in the Song Dynasty 宋代.

This research provides the bibliographic information that is important for textual criticism.

\section{Relationships between the Pusajie yishu and the Fanwang jing}

MuraKami Akiya

It has been assumed that the Pusajie yishu 菩薩戒義疏 was written on the basis of the teachings of "the importance of belief" and "becoming a Buddha by means of the precepts" encounterd in the Fanwang jing 梵網経. These same teachings are also given in the Yingluo jing 珼珞経 however. Therefore, I will examine how the Pusajie yishu interprets the difference of between the relevant sections of these two sutras. Such an analysis clearly shows that the Fanwang jing admits the existence of avijñapti 無作, while the Yingluo jing does not. For this reason, the Pusajie yishu should be considered a commentary on the Fanwang jing.

\section{The Significance of the Inconceivable for Zhiyi}

KaSHIWAGURA Akihiro

For Zhiyi, the concept of the inconceivable does not mean mysterious. The inconceivable is marked by enlightenment, the Buddha' wisdom, and the perfect teaching. It is understood as non-discrimination, non-existent, inexpressible, inapprehensibility, and ineffable. The inconceivable is explained as without subject and without object, without activity, without perception, non-front and non-back, non-length and non-width, non-identification and non-difference, the unitary while identical with three, three as selfsame the unitary, the unitary as selfsame with the many, the many as selfsame with the unitary. It means nonabiding, and non-abiding means the always now. This concept is based on the Lotus sutra. In this paper, I considered that we should understand "the thousand realms replete within an instant of thought" (一念三千), the One Vehicle (一乗), and the Mahayana (大乗) by 
the inconceivable.

\section{The Identity Simile in the Post Shanwai Group's Doctrine}

\section{YuBA Naoko}

In the Shanjia/Shanwai debates, the controversy over interpretations of Tiantai doctrine in the Song, raised a significant issue: do the Truth of Emptiness (空諦) and the Truth of the Mean (中諦) include Three Thousands appearances（三千相） concretely? Objecting to Shanjia masters who taught that each Three Truths (三諦) includes Three Thousand appearances, 仁岳 Renyue and 従義 Congyi, the Post Shanwai group (後山外派), argued that the Three Thousand appearances must belong only to the category of the Truth of Provisional Positing (仮諦). This study focuses on the similes (especially mirror and magic ball) that the two masters used in treating such problems as "only positing three thousand" 唯仮三千, and deals with their expressions of identity（相即）in relationships of the Three Truths showing how these were represented in images.

\section{Ji's Interpretation of the Two Gotras of Mahāyāna}

TADA Osamu

The two gotras of the Mahāyāna consist of the prakrtistha-gotra and the samudānittagotra, Ji 基 differentiated the samudānita-gotra from the newly impressed pure bija. Such an interpretation is not seen before $\mathrm{Ji}$.

Xuanzang 玄牀 translated prakrtistha-gotra and samudānita-gotra as benxingzhuzhongxing 本性住種姓 and xisuochengzhongxing 習所成種姓. Previously, the two words had been translated as xingzhongxing 性種性 and xizhongxing 習種性. When these terms appear in the Renwangboreboluomijing 仁王般若波羅蜜経 and the Pusayingluobenyejing 菩薩瓔珞本業経, the scriptures place them both before the darśana-mārga. I infer that this influenced Ji's interpretation.

Xuanzang's interpretation of the two gotras of Mahāyāna is not clear, but I deduce that it was diffefent from Ji's. My reasons are the following:

i) Scriptures translated by Xuanzang do not reject an interpretation that samudānitagotras are the newly impressed pure bïjas. 
ii) The Yuqielunji 瑜伽論記 says that Dharmapāla preached that samudānita-gotras occured in the darśana-mārga. In the early Tang, the source of Dharmapāla's theory must have been Xuanzang.

iii）Huijing's 慧景 theory was ahead of Ji's. According to the Yuqielunji, Huijing's interpretation of the two gotras of Mahāyāna was similar to Dharmapāla's.

Ji's Chengweishilun shuji 成唯識論述記 has been described as faithful to Xuanzang's teachings. But it is probable that Ji added his original opinions to the Chengweishilun shuji.

\section{Wŏnhyo's 元暁 View on the Concepts of Universal Principle 理 and Particular Phenomena 事}

ITō Hisanori

The famous Korean scholar-monk Wŏnhyo 元暁 (617-686) makes use of the concepts of the Universal Principle 理 and particular phenomena 事 in interpreting the doctrine of two aspects, i.e. Suchness 真如 (tathatā) and the cycle of birth and death 生滅 (samsāara), included in One Mind 一心二門, doctrine set forth in the Dasheng qixin lun 大乗起信論.

My paper examines the differences in Wonhyo's view on the concepts of Universal Principle and particular phenomena when compared to the theory put forward by Fazang 法蔵, Third Patriarch and systematizer of Huayan philosophy in China.

Wŏnhyo similarly links the two concepts to the theory of three natures 三性説 and declares the Universal Principle and particular phenomena to be mutually fused 理事融通. However, he does not seem to be actively making use of or following a clear Huayan doctrinal agenda.

Fazang, on the other hand, though heavily relying upon Wonhyo's commentary in his interpretation of the Dasheng qixin lun, introduces the doctrine of the mutual interpenetration between the Universal Principle and particular phenomena 理事交徹 in the explanation of the two aspects included in One Mind. This allows him to reformulate and further refine his presentation, from the viewpoint of the Huayan philosophy. 


\section{Fabao's Yisheng foxing jiujing lun and Jingyingsi Huiyuan's thought}

ONOSHIMA Sachio

The Yisheng foxing jiujing lun 一乗仏性究竟論 is a work by Fabao 法宝, who is famous for criticizing the Triyāna doctrine of Xuanzang 玄弉 and his disciples. Volumes.1, 2, 4 and 5 of the Yisheng foxing jiujing lun were discovered at Ishiyama temple 石山寺 in Ōstu City 大津市 in 1986. Since then, this text has been studied extensively, but there still remain issues that have not been resolved. One of these concerns the question of the doctrinal foundation of the Yisheng foxing jiujing lun.

In this study, I point out parallel sentences between the Yisheng foxing jiujing lun and Jingyingsi Huiyuan's 浄影寺慧遠 works regarding the definition of Buddha Nature and other topics. In doing so, I argue that the Yisheng foxing jiujing lun is based on Huiyuan's thought.

\section{The Influence of Zongmi's Teachings on the Korean Monk Chinul: Especially on the Theory of Spiritual Awareness}

Hu Jian-ming

As the founder of the Chogye (曹渓) order, Chinul (知昞, 1158-1210) was an important scholar-monk in Korean Buddhist history. Together with Ǔich’ŏn (義天, 1055-1101) of the Ch'ónt'ae (天台) order, they were called the Two Great Ones.

As is generally known, the Sŏn (禅) Buddhism of the Korean Peninsula was introduced by Silla monks who had been to China. Among these Chan sects, most accepted the teaching system of Hongzhou Chan Buddhism. Chinul was a monk of the Sagul san（閣崛山） school which was one of the original "nine mountain" schools of early Korean Sŏn Buddhism. Nonetheless his Sŏn thought also accepted the influence of the Dahui (大慧) Chan teachings which were prevailing in the Southern Song Dynasty, and there is a close relationship between his thought and the Heze（荷澤）Chan of the Tang Dynasty. Chinul's Sŏn thought was especially deeply tinted with Guifeng Zongmi's theories of "Sudden and Gradual Enlightenment" and "Spiritual Awareness," and on that basis he set up Huayan Chan teachings of his own.

This paper will concentrate on Zongmi's thought of "Spiritual Awareness" which ap- 
peared in Chinul's Sŏn thought. Namely, I examine how Chinul understood and assimilated Zongmi's thought of "Spiritual Awareness" and developed it in his own teachings, and the nature of their intellectual relationship and historical position. Consequently, I concentrate on Chinul's Pŏpchip pyŏrhaengnok chŏryo pyŏngip sagi (法集別行録節要並入私 記) and simultaneously examine his Chinsim Chiksol (真心直説) in order to demonstrate his acceptance of Zongmi's theory of "Spiritual Awareness."

Of course, the study of Chinul's Sŏn thought is not only a problem of Korean Buddhist history, but is also a very important element for understanding Buddhist thought of the Tang and Song Dynastys.

\section{Is Daoxuan Truly the Patriarch of Huayan?}

IBUKI Atsushi

Daoxuan (道璿) was invited to Japan from Tang (唐) China to promote the transmission of the Buddhist precepts. One of the generally accepted opinions about him is that he was the patriarch of Huayan (華嚴). But according to my analysis, the only basis of this opinion is Gyōnen (凝然)'s idea. Upon what did he base this idea? My conclusion is as follows.

1. He read Saichō’s Naishō buppō sōjō kechimyaku fu 内證佛法相承血脈譜 and recognized that Puji (普寂), Daoxuan's master, was a resident of the Huayan si (華嚴寺).

2. He mistook the Huayan si at Luoyang (洛陽) where Puji resided for a temple of the same name in Zhongnan shan (終南山), the southern suburb of Changan (長安), because the former's name was changed before Puji's death and the later was still flourishing in Gyōnen's time.

3. He misunderstood that Puji and Doaxuan were patriarchs of Huayan because Hayan si in Zhongnan shan was the most famous center of the Huayan school.

Since Gyōnen's idea was based on his misunderstandings, we must alter the traditional view. 


\section{Commentaries on the Yunyan baojing sanmei}

KoBAYAKawa Kōdai

The Yunyan baojing sanmei 雲嚴宝鏡三昧 is usually placed at the end of the Zhicheng zhuan 智証伝 written by Juefan Huihong 覚範慧洪 (1071-1128). However, it was originally an independent volume. According to Juefan's Chanlin sengbao zhuan 禅林僧宝伝 (1122), Yunyan Tansheng 雲爰是晟 (782-841) granted the original text of the Baojing sanmei 宝鏡三昧 to Dongshan Liangjie 洞山良价 (807-869), a text now known as an anthology by Dongshan. Juefan added some notes to the text. Viewing the notes, one must conclude that this volume was used as a textbook with additional oral interpretation.

There are notes quoted from Juefan's works such as the Chanlin sengbaozhuan, a fact which makes it possible to figure out interpretations. On the other hand, there are some original notes, especially those related to yigua 易卦, for which the source is not recognized. Regarding these facts, this volume must have been established after the compilation of the Chanlin sengbaozhuan since, firstly, Juefan mentions yigua in his late years and, secondly, the text differs from what is written in the Chanlin sengbaozhuan.

Moreover, Juefan understood that Yunyan's doctrine was based on pianzheng huihu 偏 正回互 which is preached in the Baojing sanmei. Hence, he prefixed the Baojing sanmei with Yunyan's name.

\section{Saichō's Idea of the Six Identities}

KuUCHI Gyōdai

In his Ganmon 願文 written when he entered Mt. Hiei, Saichō referred to the 4 th of the Six Identities 六即, the Identity in Outer Appearance 相似即. Thus we know that he had already read Zhiyi's Mohe Zhiguan. In addition, in his Shugokokkaishō 守護国界章 he coordinates the Six Identities with the Five Stages 五位 of the Yogācāra, but this is nothing more than a coordination based on the relevance of the aspiration to awakening 発心.

In his Shugokokkaishō, Saichō highly esteemed the Avatamsaka sutra, using a sentence from this text as proof of the fifth of the Six Identities, Identity in Partial Realization 分証 即. However by the time he composed his Hokkesh $\bar{u} k u$ 法華秀句, he had lowered his estimation of the Avatamsaka, and he does not quote it in his proof of the idea of Attained of 
Buddhahood in this Very Body 即身成仏.

\section{The Place of the Min'yu benwakushō in the Dispute between Saichō and Tokuitsu}

YosHIDA Jijun

The dispute between Saichō 最澄 (767-822) and Tokuitsu 德一 (?-842?) raised a number of serious problems for following generations of scholar-monks. The interpretation of sokushin jōbutsu 即身成仏 is one of these problems. Saichō's disciples attempted to resolve this issue by resorting to “answers from China” (tōketsu 聿決). Although Anne 安慧 (794?868) discussed the problem of sokushin jōbutsu in his Min'yu benwakushō, it has so far been not pointed out that the Min'yu benwakushō refers to an anonymous work entitled Tōketsu (A collection of Answers from China). In this study, I argue that in the Min'yu benwakushō, Anne attempts to solve the problem of sokushin jōbutsu on the basis of the arguments provided in the Tōketsu.

\section{Annen and the Samaya Precepts: On the Shichishu (Seven Groups of Buddhists)}

\section{TERAMOTO Ryōshin}

The samaya precepts are the precepts of esoteric Buddhism, mainly interpreted in the Mahāvairocana-sūtra and Dainichikyō-gishaku. Annen, a scholar-priest of Tendai, often referred to the Samaya Precepts. Annen separated the precepts into seven groups and discussed them from the point of view of the absolute and the relative.

The seven kinds of precepts are the Samaya Precepts, another name which appears in the Mahāvairocana-sūtra and Dainichikyō-gishaku. These are divided into receiving precepts simultaneously and independently. If simultaneously, one receives the ten and the fortyeight minor commandaments prescribed in the Brahmajala-sütra. Unlike the precepts of the Brahmajāla-sūtra in the perfect teaching, the esoteric Buddhist interpretation is given as the Samaya Precepts.

If independently, one receives the precepts gradually. If gradually, the most important precept is the seventh. Annen made this the precepts of the Jimyōkonkai 持明禁戒. This is different from the capacity to understand the teaching of the seven kinds of precepts, being rather the precept of repeating mantras after abhișeka. Probably, it is a result of Annen es- 
teeming the precepts in the Mahāvairocana-sütra.

Annen separated the precepts held the Buddhas and bodhisattvas so the mandala in this fashion. We could interpret Samaya Precepts used generally for acceptance of the seven kinds of precepts and the separate seven types from the third level to the center are the same.

\section{New Knowledge Obtained from the Sanjiao buqi lun 三教不商論 Introduced to Japan by Saichō and Kūkai}

FujII Jun

A manuscript of the Sanjiao buqi lun, Discourse of Three Religions, was found recently, and was reprinted.

It is very rare that discussions between the three teachings in the Tang dynasty exist, and it is very important that their original was brought back by both Saichō and Kūkai.

I speak about the new information provided by the discovered manuscript in this report.

1) The difference of a date between the document of the Tendai Hokkeshü Denbō-ge 天 台法華宗伝法偈 and the colophon of the manuscript in Ishiyamadera is three days. From the Ishiyamadera manuscript, we learn more of the activity of Saichō. As for the Tendai Hokkesh $\vec{u}$ Denbō-ge, its authorship has been questioned, but it might refer to some old records.

2) It has been thought that the Taishüroku, Taizhou Catalog, and the Esshüroku, Yuezhou Catalog, record the Buddhist Scriptures which Saichō collected and copied in each distinct. However, from the colophon of the manuscript in Ishiyamadera, it is now known that Saichō wrote in the Yuezhou Catalog what he copied in Taizhou. It is necessary that the problem of the Taizhou Catalog and the Yuezhou Catalog be reexamined.

3) It is thought that the Sanjiao buqi lun was put in the 26th box of the Mt. Hiei storehouse, where Buddhist scriptures were kept, while almost all temples at Mt. Hiei were destroyed by fire in 1571.

4) Kükai dropped in at Yuezhou province when he returned home from China, and might have seen the catalogs which Saichō left. He would have thought of collecting not only Buddhist Scriptures but also documents of Confucianism and Taoism.

5) The main temples of Shingon copied Buddhist scriptures which Kūkai brought from 
China into Japan, and collected them.

\section{Kakuban's Views on the Equality of Body and Mind}

KAMEYAma Takahiko

In his Hannyashingyō hiken ryakuch $\bar{u}$ 般若心経秘鍵略註, Kakuban 覚鎬（1095-1143） explains the non-duality (funi 不二) and identity (sokuitsu 即一) of mind and body based on the non-duality of the Matrix (taizō 胎蔵) and Diamond (kongō 金剛) realms and the non-duality of reality ( $r i$ 理) and wisdom ( $c h i$ 智). He further emphasizes that both mind and body are equivalent to One Mind (isshin 一心), which is reality just as it is. According to the Kakuban shōnin denbōedangi uchigikish $\bar{u}$ 覚鋞聖人伝法会談義打聞集, however, Kakuban instructed his disciples in the duality (nini 而二) and individual equality of mind and body, which respectively correspond to the mind and body of Mahāvairocana. From his explanation of the five-viscera visualization ( gozō sanmajikan 五藏三摩地観) in the well-known Gorin kujimyō himitsushaku 五輪九字明秘密釈, it is clear that Kakuban's fundamental view of the five viscera was profoundly influenced by this idea of the dual equality of body and mind, rather than their simple non-duality.

\section{Interpretation of the Paragraphs on the "Three Kalpas" in the Dari jing (Mahā- vairocana-sūtra) in Medieval Shingon Esoteric Buddhism}

ŌSHIKA Shin'ō

Dōhan（道範）, a Shingon scholar-monk, was one of the Koya-Hakketsu（高野八傑）, and active on Kōya-san (高野川) in medieval times.

Dōhan was one of the first to develop a theory of practice grades, fixing the bases of the Shoji-sokugoku theory (初地即極説).

This paper explores how Dōhan dealt with the relation between the eighth, and ninth stages of mind (第八- 第九住心) and the first grade shoji (初地) of the tenth stage of mind (第十住心) at paragraphs of the “Three Kalpas" in the Dari jing (大日経; Mahāvairocana-sūtra).

Dōhan quoted the doctrines of his master Jōhen（静遍）for his interpretation of the paragraphs on the "Three Kalpas", especially on the paragraphs focusing on a meeting point 
between the tenth stage and the other stages of mind. Jōhen and Dōhan developed original theories of practice grades. Those theories are applications of the idea of Ukyō-munin (有 教無人) which is a doctrine of the Tendai（天台）school, establishing a false stage（擬儀 門), and dividing Shingon ascetics into two groups, one of which can enter Shingon practice directly and the other of which has to detour.

\section{Shingon Buddhist Doctrine as Seen in the Tokiwai-dono kiroku: Focusing on the Teachings of Dōjun}

NAKAMURA Honnen

The Tokiwai-dono kiroku（常盤井殿記録）is a record of Shingon Buddhist doctrinal debates held at the palace of the retired emperor Kameyama, carried out eight times between April $14^{\text {th }}$ and $29^{\text {th }} 1305$ by such representative Shingon monks of the time as Ryōhen ( $了$ 遍), Jitsuei (実㪍), and Dōjun (道順).

This text circulated at different times under various titles including Shingon shügi seitan $s h \bar{u}$ (真言宗義精談集), Dōjun ki（道順記)，and Daigo-gata kyōsō shūgi（醍醐方教相 宗義). The cover has a later emendation reading Go-uda hōo (後宇多法皇), and some connection can be conjectured.

The Tokiwai-dono kiroku contains questions and answers concerning such Shingon doctrinal issues as attaining buddhahood, the capacity of the trainee, praxis, esoteric vs. exoteric, and so on. In particular the need for practice, the intermingling of the male and female, and the compassion of the own-nature dharmakāya (自性法身) and suchness and conditioning are debated.

Dōjun has a central role in the Tokiwai-dono kiroku, and he is famous as the teacher of Monkan (文観), who is connected to Tachikawa-ryū (立川流). This work is important as a resource for examining the teachings of Monkan and Tachikawa-ryū.

\section{A Consideration of Hōnen's Portrait "Ashibiki-no-miei"}

TAKAMA Yukari

The "Ashibiki-no-miei," kept in the Nison-in and designated as an important cultural property, is the oldest extant portrait of Hōnen (1133-1212). However, since the screen 
has darkened owing to the smoke of incense or oil, the image cannot be clearly seen with the naked eye. Therefore, whether Hōnen is the subject of the portrait or not is uncertain. After details of the portrait were observed using infrared photography, and through other means, the image appears to have been drawn by someone who was looking at Hōnen himself. It does not appear to have been drawn from a previously existing image, such as that which had been created by a first-class painter. These observations support the notion that the "Ashibiki-no-miei" is a work made by Kujō Kanezane, a followerer of Hōnen's, just before Hōnen's banishment in 1207 .

\section{Senshi (先師, previous master) in Ryōchū's Writings}

NUMAKURA Yūto

Ryōchū (良忠)'s tremendous volume of writings is called “Hōmushō (報夢鈔)" as a whole. In these writings, he quotes not only a great deal of literature but also oral instructions (口伝) and hearsay (伝聞).

In so quoting, some of the names of persons are given anonymously. They are mentioned for example as “aruga iwaku (或云)” or “ichigi ni iwaku (一義云).” One such expression is “Senshi iwaku (先師云)."

“Senshi (先師),” a previous master, is believed to refer to Shōkō (聖光), Ryōchū's master. Gizan（義山） of the Edo period, however, claims that "Senshi" means Ryōhen（良 遍).

Shōgei (聖四)'s Nyushō (糅鈔), a commentary on Ryōchū's Denzuki (伝通記), confirmes that most of the usages of the term "Senshi" in Ryōchū's Denzuki refer to Shōkō. In addition to Shōkō the term sometimes points to Chōken (澄憲) or Shōshin (証真). It is necessary to examine the usages of "Senshi" in all the writings of Ryōchū.

\section{Pure Land Documents in the Library of the Chishakuin}

NoJIMa Satoru

Chishakuin 智積院 is a Chisan sect (Shingon) temple with a library keeping many documents. This report focuses on Pure Land documents in the library of Chishakuin. One of them is called Shin Bunko 新文庫. Shin Bunko contains the following Pure Land documents: 
Amidakyō shikikigaki 阿弥陀経私聞書, Jōzen kedaishō 定善華台抄, Himitsu nenbutsushō 秘密念仏抄, Amida taishinshō 阿弥陀大心抄, Ichigo taiyo himitsush $\bar{u}$ 一期大要秘密集. In addition, there is a list of documents called Henshōin seikyo mokuroku 遍照院聖教目 録. These manuscripts were written in medieval days, and unknown in Pure Land studies so far.

\section{The Foundation Story of Katsuōji-Nikaidō, the Fifth of the Twenty-five Sacred} Sites of St. Hōnen

According to various biographies of Hōnen (法然), Katsuōji-Nikaidō（勝尾寺二階堂） is the place where he spent four years before he got permission to go back to Kyoto. He went there after he was exempted from banishment in 1207 . The foundation story of Katsuōji says that Shandao (善導) imparted the commandments of the Jōdo sect to Hōnen in Nikaidō and they left their shadows on the wall plate. None of Hōnen's biographies record this, but it is confirmed in works since the Settsunokuni-katsuōji-ryakuengi (摄津国 勝尾寺略縁起), which was published in 1680. Here, however, I newly introduce historical materials such as the Hōnen-ki of 1666 and the Ōchōzan-katsuōji-nikaidō-engi (応頂 山勝尾寺二階堂縁起), which was written by Kaoku (珂憶) in 1707. I compare the contents of these works with the contents of the already-published works of that time and demonstrate the transformation of the foundation story of Nikaidō.

\section{Sōjun's View of the Myōkonin and His Myōkonin-den (Five Volumes)}

TAtsuguchi Myōsei

The first Myōkonin-den, the Shinmon Myōkonin-den, was recorded and compiled by Gōsei 仰誓. He collected those stories when he met myōkonin personally or he heard the stories from people close to him. Gōsei's view of myōkonin was consistent. Gōsei thought devotees in Jōdo Shinshū must to do nembutsu and go to the temple to listen to the teachings of Buddhism.

The Myōkonin-den (Five Volumes) was compiled by Sōjun 僧純. He had a different view of myōkonin from that of Gōsei. Sōjun thought myōkonin have a special character. Some 
of them demonstrated miracles when they died.

In this paper, I consider why Sōjun compiled the Myōkonin-den (Five Volumes).

\section{On the Shinran Shōnin Reizui-hen}

KIKUFUJI Akimichi

The purpose of the essay is to clarify the characteristics and significance of the legends of Shinran through the methodology of philological study and fieldwork, which is mainly based upon Shinran Shōnin Reizui-hen edited and published by Shōjubō Sōjun, a monk of the Jōdoshinshū Hongwanji-ha, in 1861, the year of the 600th Memorial for Shinran Shōnin.

\section{Characteristics of Shinran's Nembutsu Thought, Especially the Difference from Hōnen's}

KōBAI Eiken

Shinran was Hōnen's disciple. As he says in "A Record in Lament of Divergences": "As for me, I simply accept and entrust myself to what my revered teacher told me: 'Just say the nembutsu and be saved by Amida; nothing else is involved'." He thereby adhered faithfully to Hōnen's other-power teaching. His concept of Nembutsu is also close to Hōnen's. However, for Hōnen, the Nembutsu is uttered in order to be born in the Pure Land. For Shinran, one does not say the Nembutsu to be born in the Pure Land. Shinran's Nembutsu is for offering thanks to Amida Buddha.

\section{Shinran's Acceptance and Development of the Ten Thoughts in the Wangsheng}

\section{Lunzhu}

TAKEDA Susumu

In this paper, I clarify the ten thoughts (shinian 十念) which Tanluan wrote about in his Wangsheng Lunzhu. Moreover, I examine how Shinran accepted and developed this idea.

In the section on eight questions and answers (Hachiban-mondō) from the Wangsheng Lunzhu, there are mentioned people who are of the lowest rank of the lowest grade of birth 
(下品下生) who have the ten thoughts. This refers not to a recollection of Bodhisattvas but to faith (信心). It is caused by hearing the Name of Amida Buddha.

The ten thoughts are understood by Shinran as the Nenbutsu because he emphasized rebirth based on faith, which comes from hearing the Name of Amida Buddha in the passage declaring the fulfillment of the primal vow.

\section{Shinran's Thought of $\bar{O} c h \bar{o}$ (Leaping over Crosswise) and Its Modern Meaning}

ITō Eshin

This essay intends to discuss Shinran's thought of $\bar{O} c h \bar{o}$ (leaping over crosswise) and speculate on its modern meaning. What kind of change does the salvation of Shin-Buddhism bring us? I want to clarify that it is the universal truth that Shinran's thought of $\bar{O} c h o ̄$ relieves all existence equally.

\section{A Study of Shinran's Citations of Shandao in the Section on Great Practice in the} Kyōgyōshinshō

\section{NuKina Yuzuru}

In the "Chapter on Practice" in the Kyogyōshinshō, Shinran discusses the working of the recitation of nembutsu not as an aspect of sentient beings' mind, but as Amida Buddha's Great Practice. This can be seen in Shinran's citations of Shandao's work. Among the ten citations of Shandao in the section on Great Practice within this chapter, Shinran demonstrates that the recitation of nembutsu is the working of Amida Buddha and other Buddhas (including Śākyamuni). More concretely speaking, he uses these citations to explain that the Name, which is the manifestation of the mind of Amida's Vow, reaches and becomes engaged with sentient beings through their recitation of the Name. "Namo amidabutsu" discussed in this section is not in regard to the aspect of sentient beings' mind receiving Amida Buddha's Vow, but Amida's calling toward sentient being to take refuge, or his working itself. 


\section{Attitudes Toward the Worldly Acts of Shinshū Followers in Zonkaku's Hōon (Gratitude) Ideology}

TANiguchi Tomoko

Statements concerning worldly matters appear here and there in Zonkaku's discussions of hōon (報恩, gratitude). Previous Scholars have considered this an organizational accommodation to the Honganji community. However, it is important to consider Zonkaku's purpose in writing his works and his contemporary historical situation in order to grasp his thought. To pursue this matter, I turn my attention to hōon in Zonkaku's Haja kenshōshō 破邪顕正抄。

\section{Chikū's Citations in His Jödo Wasan Shusho}

IıJIMA Noriakira

In his Jōdo Wasan Shusho 浄土和讃首書, a commentary on Shinran's Jōdo Wasan, Chikū 知空 naturally quotes Shinran himself, but he also quotes Zonkaku 存覚 extensively. On the whole, it presents an understanding based on Buddhism in general, while Shinshū doctrine is clarified in the simultaneously published Shisaiki 思斉記. The approach to quotation is an explanatory method centering on a bold focus on "meaning." Moreover, recently published works were also used.

\section{The Vijñaptimātra Thought of Ryōjin Soga: His View of the Three Aspects of Faith as the Category Represented by Amida Tathāgata}

In "Soga's view of three aspects of faith as the category represented by Amida Tathāgata," Ryōjin Soga connected three aspects of the Allaya-vijnāna in the Cheng weishi lun with three aspects of faith in the Larger Sutra of Immeasurable Life. I compare the structure of the three aspects of the Ālaya-vijñana in the Cheng weishi lun and the structure of the three aspects of faith in the Larger Sutra of Immeasurable Life, and find them to be identical. Ryōjin Soga also noted this identity. 
38. A Consideration of Life and Death in Jōdo Shinshū

KAWAMURA Ryō

The purpose of this study is to consider how the Jōdo Shinshū views life and death in terms of spiritual care. Interview research with a number of housebound seniors illustrates an attitude toward death for what it is, but there were different views of life and death which have influence on the reception of death. The views of life and death were considered from standpoints of reunion in the Pure Land and deep regret.

\section{Methodology of Shin Buddhist Welfare Practice for Disabled People: The Inde- pendent Living Movement as "The Way of Living Together with a Downward Trajec- tory"}

YORITAKA Tsunenobu

This paper considers the relation between Shin Buddhist welfare theory for disabled people and social model. In this paper, I consider the independent living movement, which is one of the practical methods of the Shin Buddhist welfare theory for disabled people. I discuss the social architectural theory based on the way of thinking which is called "The Way of Living Together with a Downward Trajectory Model."

\section{Dōgen's Acceptance of the Lotus Sutra and Tendai Theology in the Bukkyo chap- ter of His Shōbōgenzō: The Structure of Kubunkyō and Jūnibunkȳ}

SEINO Kōdō

This paper investigates Dōgen's understanding of the Lotus Sutra and Tendai theology, through the structures of the Kubunkyō (九分教, 9 part teaching) and Jünibunkyō (十二 分教, 12 part teaching) as seen in the Bukkyō chapter of his Shōbōgenzō.

Rosan Ikeda has noted Dōgen's emphasis on the Lotus Sutra and Tendai theology. There also exist studies on the Kubunkyō and Jūnibunkyō, by Shōson Miyamoto, Egaku Maeda, Kōgen Mizuno and others. Dōgen's understanding of the Kubunkyō and Jünibunkyō is based on the Lotus Sutra and Fahua xuanyi, and Dōgen identified them with the Buddha dharma. My purpose here is to illuminate the reason he did so. 


\section{Zen Master Dögen and the Da zhidu lun}

NAGAI Yoshitaka

In this article I study how Dōgen 道元 (1200-1253), the founder of Japanese Sōtō Zen, received Nāgārjuna's Da zhidu lun 大智度論. In particular, the 12-fascicle Shōbōgenzō contains many quotations of the Da zhidu lun. Dōgen recognized the difference between the bodhisattva ideal as described in the Nirvāna Sūtra and the realization of bodhisattvahood as explained in the Da zhidu lun. I argue that he adopted both concepts, but recommended the realization of bodhisattva-hood as described in the Da zhidu lun.

\section{Kikan in Medieval Sōtō Zen: The Eight Verses by Wanshi (Hongzhi)}

TATSUYA Kōdō

This paper aims to illuminate how the Eight Verses by Wanshi（wanshi hakku 宏智八句） were established as a kikan 機関. In the Middle Ages (in particular since the Muromachi period), Sōtō monks trained themselves by methods which differed from Dōgen's practice (1200-1253). One of their methods was to write a short verse called jakugo 著語 to a kōan 公案 or kikan 機関. By composing jakugo, monks expressed their level of understanding in order to be certified by their master. The Eight Verses by Wanshi are recorded in the informal sermon section of the Hongzhi lu (Wanshiroku 宏智録). In China these verses were not considered as kikan. However, later in Japan they were established as a kikan. In this article I compare the three works Ryōandai 了庵代, Mugoku daioshō shōsan agyō 無極大 和尚小参下語, and Taisō Isshū hakku no ojakugo hakku no shō 泰帠一州八何之御著語 八句之書. In dharma lectures on the Hongzhi lu, Sōto monks pointed out the importance of the eight verses and thereby the verses came into independent existence as a kikan.

43. The Meaning of Citations from the Zongjing lu 宗鏡録 in the Kensho jōbutsuron 見性成佛論 (Treatise on Seeing One's Nature and Attaining Buddhahood) in the Kanazawa Bunko Collection

Furuse Tamami

The Kenshō jōbutsuron 見性成佛論, a Zen text from the Kamakura period, contains a 
number of citations from the Zongjing $l u$ 宗鏡録.

Seven parts of the Kenshō jōbutsuron cite the Zongjing lu. These citations can be categorized in five ways: 1) direct citation; 2) indirect citation; 3) partial citation; 4) question and answer citation; and 5) answer citation.

Some scholars consider the concept of "one mind" in the Kenshō jōbutsuron to be derived from the Zongjing $l u$. However, close study of the use of citations from the Zongjing $l u$ in the Kenshō jōbutsuron suggests that the author of the Kenshō jöbutsuron does not adopt the concept of "one mind" presented in the Zongjing $l u$, which refers to all elements of the mind. Rather, the author of the Kensho jōbutsuron espouses a variant of the "one mind" concept that refers only to the pure mind, as expressed in the Chuanzhuan Xinfayao 傳心法要. Consequently, though it contains numerous citations from the Zongjing lu, the Kensho jöbutsuron cannot be said to reflect the philosophy of that text.

\section{Rankei Dōryū's Legacy Verse}

TACHI Ryūshi

Rankei Dōryū was a Rinzai monk and founder of Kenchō-ji in Kamakura. Dōryū's Legacy Verse (遺偈) wasn't printed in Genko shakusho in the Kamakura Period, but rather for the first time in a biography in the Edo Period. Dōryū's Reliquary (舎利容器) was discovered in the Kenchō-ji and upon it was carved his Legacy Verse. Thus was revealed the true form of Dōryū's Legacy Verse.

\section{Criticism of Takuan's Fudōchi (Immovable Wisdom) in Giri no Hyōban}

KASAI Akira

Fudōchi (Immovable Wisdom) was the Bible for martial arts philosophy in the Edo period. However, there existed a criticism of this Fudōchi, namely the Giri no Hyōban. The purpose of the present paper is to consider the criticism of Takuan's Fudochi in the Giri no Hyōban.

Inagaki Takanao had three misunderstandings of the ideas of the Fudōchi. First, he misunderstood it with respect to No-Mind. Second, he misunderstood it with respect to the Yagyu Shinkage School. Third, he misunderstood it with respect to the practice of Bud- 
dhism. Therefore, the criticism of Takuan's Fudōchi in the Giri no Hyōban has no validity.

\section{Transcript of a Lecture on the Hokekyō Given by Gyōgakuin Nitchō}

Terao Eichi

Gyōgakuin Nitchō was a learned priest of the Nichiren sect in the Muromachi period. Materials related to Nitchō include works he wrote himself, manuscripts in which he copied the works of others, and books he obtained from others. There are also Kikigaki, transcript of lectures of Nitchō recorded by others. In order to research Nitchō, it is important to clarify the overall picture of these materials.

Hokkesōanjō is an exposition about the Hokekyō. This is a compilation of transcriptions of lectures of Nitchō. Fifteen transcripts of his lectures have been found. Nitchō gave lectures about the Hokekyō in his early 30s, early 40s, and late 50s. Some cover whole passage, and others refer to a few parts. One lecture is given intensively. The longest transcription is the Chögakushō, composed of 38 volumes.

\section{7. “The Superiority of the Fundamental Aspect (hommon) over the Manifestation Doctrine (shakumon)" in the Early Nichiren Community}

FUSE Gikō

After Nichiren's death, a controversy arose within the community over whether or not to read the Upàya (second) chapter of the Lotus Sutra (Fangbianpin 方便品). Two positions are represented by Tenmoku 天目 (1257-1308), who opposed reading the chapter, and Niko 日向 (1259-1314) who favored it, relying on the expression běnjì suī shū bùsìyiy $\bar{\imath}$ 本迹雖殊不思議一. This controversy became one cause of the development of the Honjaku itchi-ha 本迹一致派 and the Honjaku shōretsu-ha 本迹勝劣派.

48. The Doctrine of Nagamatsu Nissen 長松日扇: The Name of the Butsuryū 佛立 Sect

TAKEDA Goichi

This paper discusses the doctrine of Nagamatsu Nissen (1817-1890), with a focus on 
the name of the movement Nissen led, namely the Karaku Honmon Butsuryūkō 華洛本門 佛立講. Nissen gave his movement the name $k \bar{o}$ 講 as the sect established by the Buddha Sákyamuni with the idea that it be the single Lay movement (zaikekō 在家講) inheriting the Buddha's intention, this name becoming the motivation for the development of Nissen's doctrine. In regard to the question of development, how did Nissen regard the name Butsuryūshū in light of the history of Lotus Doctrine? Second, how did Nissen receive and modify the use of this name from Nichiren 日蓮 and Nichiryū 日隆?

I paid attention to the way the term Butsuryūshū is used by the five patriarchs, Tiantai Zhiyi 天台智顗, Miaole 妙楽 (Chanran 湛然), Dengyō Daishi Saichō 伝教大師最澄, Nichiren, and Nichiryū. The first two used the term as a name for the "Constantly Walking Samādhi”" (jōgyōzanmai 常行三昧). For Saichō it meant the sect established by Śākyamuni Buddha. Here we can detect the usage of Nichiren and Nichiryū as well.

Thus, we understand that Nissen based the name Butsuryūshū on the usage of Nichiren and Nichiryu as the sect established by the Buddha, and that with regard to both the aspect of doctrine and the aspect of faith, Nissen took the standpoint that it is a reestablishment of the true community of Nichiren's Honge 本化 doctrine and Nichiryū's Eight Articles doctrine.

\section{Lotus Sutra Views on Buddhist Welfare}

YOSHIMURA Shōshi

In this paper I consider the modern meaning of the teachings in the Lotus Sutra, especially teachings in the air.

To realize the thought of Living Together (共生), we have to try to understand and respect one's differences, and in such a way, we have to reconstruct one's relations with others.

Those who are conceited or feel hostile appear in the Lotus Sutra. Sadāparibhūta's (常 不軽菩薩） deed will give us a useful suggestion to those who cannot find a mutual understanding. He vowed obeisance to whomever he happened to meet. His deed is regarded as the way to respect the possibility of growth and improvement in the human essence of all people. This also shows us the way to wait for them to seek dharma, as well as the way to reffect one's self-conceit. 
In conclusion, I distinguish the idea of Buddhist welfare in the Lotus Sutra. It shows the way to consider all things as what give us awareness, sympathize with others' pain or sadness, stand close to others with patience, and share the joy of life.

\section{The Structure of the Sānbăo gănyìng yàolüèlù and Its Influence on Later Litera- ture}

Matsumura Hisashi

The Sānbăo gănyìng yàolèlù 三宝感応要略録 was lost in China where this work was compiled, but transmitted in Japan. Moreover this collection of Buddhist narrative stories took on the role of an original source book for much classical Japanese literature. Because of this fact, this text has been studied by many Japanese scholars, but all scholars treated this text as a source book and did not examine this text itself. In his recent work, Dr. L $\breve{i}$ Míngjìng reexamined this text extensively from the stand point of Sinology. He clarified many points which Japanese scholars had overlooked. Indeed Dr. Lü's work is an epochmaking one, but there remained some problems. For examples, he asserted that the way of division of the Sänbăo gănying yàolüelù is based on the notion of the three jewels. In the first two Buddha and Dharma, there is no problem, but the third, Sangha, means the Buddhist order. The subject of all stories in the third part of the Sānbăo gănying yàolüèlù is the bodhisattva. This particularity is still to be explained.

Dr. Li fixed the boundary between the 37th and the 38th stories of the second part. However the topic of these two stories is regaining of life, and these two should be treated as belonging to the one and same group.

The motif of regaining life is found in the Sānbăo gănying yàolïèlu here and there. Each story of this collection does not make a group only with neighboring stories but also with stories which share the same or similar motif.

Especially this motif of regaining life was adopted by the editor of the Hyakuzahōdankikigaki-shō. In this case, even if the Sānbăo gănying yàolüèlù is not a direct source of the Hyakuzahōdan-kikigaki-shō, it may be possible that the editor of the latter text would have made reference to it on this theme. 


\section{Genealogy of Mandhātar}

The name of an old sage, Mandhātar, is attested in many Vedic texts. However the characterization of this figure has not been well discussed. This paper attempts to show in which genealogy of sages in ancient India Mandhātar can be positioned, and what role he played in Indo-Aryan and Indo-Iranian societies.

The word mandhātár- goes back to Proto-Indo-Iranian * manz-d ${ }^{h} \bar{a}-t a r-/-t r-$, meaning 'who puts [instruction, doctrine etc.] in ones own mind,' as its etymology and the corresponding verb in Avesta suggest. This agrees with the usage of the word in the Rig-Veda as a noun denoting 'sage,' or as the proper name of a legendary poet. The name is also referred to in the so-called Pravara literature conveying the genealogies of sages, in which Mandhātar is regarded as the founder of the Harita family, one of the Bharadvāja's subfamilies. In the Gopatha-Brāhmaṇa, on the other hand, we come across a legendary king (presumably) of Videha, Māndhātar Yauvanśva (always - $\bar{a}$ - in Māndho ${ }^{\circ}$ ), whose father Yuvanāśva is the sage's name in the Harita's lineage above. The king therefore evidently represents a different figure from the sage Mandhātar, though later indigenous annotators often confuse the two. Māndhātar's story, mythologized and popular in epic and Purāṇic texts, also appears in Buddhist literature where he apparently is an ancestor of Buddha.

\section{Dharmalakșana in the Mokșadharmaparvan of the Mahābhārata: The Meaning of the Fourth Dharmalakșaṇa Artha}

Fuנr Seiko

The dharmalaksana ('the Definition of dharma') is the the key to understand dharma, one of the most significant concept in India. In the Manusmrti (Mn) the four dharmalakșaṇas are described, namely, veda, smrti, sadācāra and ātmatușți (Mn2. 6, 12). The Mokșadharmaparvan (Mdh) of the Mahābhārata (MBh) also alludes to the four dharmalakșanas (MBh12. 251); the first three are the same, but the fourth is there artha. In MBh12. 251-256, Bhiṣma first mentions these four dharmalakșanas to Yudhișthira and then explains in detail the meaning of the fourth, artha (MBh12. 251). Criticized by Yudhișthira (MBh12. 252), Bhīṣma narrates further the dialogue of Jājali and Tulādhāra (MBh12. 
253-256).

Atmatuști as the fourth dharmalakșana in Mn means mental satisfaction of the learned, i.e. those learned in the Vedas and Smrtis. Hence this standard depends on and accords to the behaviors of Brahmins. In contrast, artha in Mdh means benefits for all people. In the dialogue of Jājali and Tulādhāra, the latter, though a merchant, teaches dharma to the ascetic Brahmin Jājali, laying stress on ahimsā and abhaya, which also suggests that dharma herein is more universal and conforms to wider society. From this analysis, I conclude that MBh12. 251-256 intends to proclaim a new concept of dharma, more universal than the one described in $\mathrm{Mn}$.

\section{Jainism Under the Kushan Dynasty}

TAKAHASHI Takahide

To study the religious condition of the days of the emergence of Mahāyāna Buddhism, we take up Jainism under the Kushan dynasty. On the basis of many sculptures and inscriptions recovered from Mathurā, we find that the Kankālī Tîlā mound was an important centre of Jainism. Worship of mysterious symbols, stūpas, and of images of Tïrthankaras, mostly in dhyāna-mudrā, were in vogue. Inscriptions tell us that there were 4 ganas (schools) in the Jain church, and the schools were further subdivided into several sects called kulas, śākhās and sambhogas. Lay Jains, mainly wives and daughters of artisans and merchants, seem to have maintained a strong sense of belonging to such schools and their sub-sects. The Jain inscriptions inform us that donations were made at the direct request of monks and nuns. Such direct requests are rare in Buddhist inscriptions of those days. Some bas-reliefs of the pedestals of Tìrthankkara images demonstrate the existence of Śvetāmbhara sect as well. We cannot find the idea of parināma in the dedicatory phrases in Jain inscriptions. We likewise cannot find any evidence for temples maintained by specific guilds, as we see with the Pravārika-vihāra and Kāșthikìya-vihāra in Buddhist inscriptions. Lay Jains, having a strong sense of belonging to certain sects, aspired for their own religious perfection. 


\section{Symptomatology of Patients with Incurable Diseases in the Carakasamhitā: Stud- ies Focused on Thirst}

In ancient India, physicians were not to treat incurable patients with arișta (fatal signs) and needed to discriminate curable diseases from incurable ones before they started treatment. Thirst was the most common medical term considered in connection to arista used in the Indriyasthāna of the Carakasamhitāa. Following thirst were unconsciousness, debility, fever, diarrhea, cough, swelling, dyspnea, insanity, perspiration, hiccup, anorexia, emaciation, anemia, and hemorrhage, in descending order. The frequency in the use of thirst as a sign of incurable and curable diseases was 31 cases $(26.7 \%)$ and 85 cases $(73.2 \%)$ respectively among the 116 showing symptomatic thirst. The majority of cases of curable diseases were pittaja diseases and febrile diseases. Diagnostic probability of incurability with thirst alone was $26.7 \%$. When thirst was combined with another symptom, it was $2 / 3$ $(66.7 \%)$ with thirst + swelling, 4/8 (50.0\%) with thirst + hiccup, and 8/18 (44.4\%) with thirst + unconsciousnes. When considering 3 symptoms, it was $2 / 2(100 \%)$ with thirst + dyspnea + diarrhea, 3/4 (75.0\%) with thirst + dyspnea + unconsciousness, $6 / 10(60.0 \%)$ with thirst + fever + debility, $4 / 7(57.1 \%)$ with thirst + unconsciousness + hiccup. Thirst alone showed a fairly low connection to fatality, but the percentages rose significantly when it was conbined with other symptoms.

\section{Literary Style in Ancient India: Focusing on the Kā vyādarśa of Dandin}

WADA Yügen

The Kävyādarśa (Mirror of Poetry) of Dandin, an $8^{\text {th }}$ century rhetorician, is one of the two greatest works in early classical rhetoric in India. In the Kā vyādarśa, Dandin devotes the first chapter, entitled Mārgavibhāga (Division of Style), to an explanation of Styles and Ten Poetical Virtues (guna).

It is well known that it is Dandin who connected literary style with poetical virtues for the first time in the history of Indian classical rhetoric. He used "mārga", "paddhati" and "vartman," all meaning "the road," instead of the term "rìti", which usually means "Literary Style". 
This paper aims to illuminate these unique arguments of Dandin concerning literary style.

According to the Harșacarita of Bāna, a $7^{\text {th }}$ century writer, at that time in India, each region had expressional characteristics, which could be called literary styles, of which Dandin designated the Vaidarbha Style and the Gauda Style as the having clearest character.

While Dandin gives ten gunas as the characteristics of Vaidarbha Style, he argues that Gauda Style is generally its opposite.

Thus, through examining these ten gunas, I would like to clarify the characteristics of these two styles, and illuminate Dandin's conception of literary style.

\section{On samavāya and ayutasiddha in the Vaiśșika}

Hirano Katsunori

This paper considers the concept of ayutasiddha (entities that fix without being separate from each other) in order to understand the concept of "inherence relation" (samavāya) in the Vaiśeșika. The concept of ayutasiddha, which is referred to in the definition of "inherence relation" itself in the Vaiśeșika's texts and shows the condition of relata of inherence, is explained through the negation of the concept "separate existence" (yutasiddhi). Therefore, the concept of yutasiddhi must first be analyzed for an understanding of ayutasiddha. In this paper, I will trace explanations for the concept of yutasiddhi in transitory entities and, therefore ayutasiddha in the Prācina Vaiśeșika, consulting the Padārthadharmasamgraha and the commentaries on the Padārthadharmasamgraha-the Vyomavati, the Nyāyakandali, and the Kirañāvalì. Moreover, I will consider a logical fault in the inclusion of the word ayutasiddha in the definition of "inherence relation."

\section{7. (A-) parigraha- in the Early Buddhist Canon}

INABA Yuima

The early Buddhist texts often discuss non-possession. However, the meaning of this term and its position in Buddhist thought remains unclear. In this paper, I considered the term pariggaha-, which means "taking up, possession, property," as it is used in gātha sütras and the four Nikāyas in order to clarify the meaning and position of non-possession. 
As a result, in terms of meaning, I show that pariggaha-means both the act of taking and the things one possesses as a result of that action. In terms of the position of non-possession in Buddhist thought, it is clear that while in gāthā sütras non-possession is explained as a characteristic of a religious ascetic, in the four Nikāyas it is presented as the characteristic of Brahmā and the inhabitants of Uttarakuru. In other words, there is difference in the găthā sütras and the four Nikāyas concerning the treatment of the concept of non-possession.

\section{Devatānussati from the View Point of Self-others Meditation Practice}

INOUE Vimala

Devatānnusati (recollection of deities) is the last item of six recollections the others being recollections of the Enlightened One, of the Dhamma, of the Sangha, of virtue, and of generosity.

In the practice of devatānussati, a meditator should recollect deities, their special qualities and one's own special qualities which are equal to those of the deities, making the deities stand as witnesses. This alternation of objects leads the meditator to deep insight into the nature of duality: inside and outside or oneself and others. In this way, the meditator learns the limitation of duality and transcends co-dependent relationships with others, including gods and deities.

The purpose of devatānussati is not to experience a mysterious union with deities but to acquire an adequate concentration for further insight meditation (vipassanā) by suppressing existing mental defilements. The Buddha recommended six recollections for noble disciples, because they are free from misrecognizing a god (a deity) as the Enlightened One (Buddha).

In both recollection of the Enlightened One and recollection of deities, meditators are requested to focus on very complicated objects, such as the ten special qualities of the enlightened one and so on. The reason of this complexity is to prevent meditators from indulging in an absorption concentration which easily produces mystical union and mythical stories.

When an unenlightened meditator experiences these mystical experiences, s/he may easily embark on creating a new religious system that is very similar to the Buddha's teaching, 
misunderstanding one's beloved god as a Buddha (or replacing the Buddha with one's beloved god).

In the Visuddhimagga, "a figure of the Enlightened One created by Māra" is mentioned from an old Sinhala source. An elder monk in the story used it skillfully in order to develop vipassanā. But a meditator who is immature in vipassanā practice may be trapped in this kind of mystical vision and start constructing pseudo-buddhistic belief systems, by creating a new Buddha and bodhisattas.

\section{Sādhāraṇa-Kamma in Theravāda Buddhism after Dhammapāla}

HAYASHI Takatsugu

In my previous paper, "Sādhärana-Kamma in Theravāda Buddhism from the Pāli Canon to Buddhaghosa," IBK 59,1 (2010), it was shown that the Theravādins were careful not to include sādhārana-kamma. Buddhaghosa avoided this term, although this notion was discussed already in the Kathāvatthu and the Vimuttimagga, and was thus familiar to him. However, we should not overlook that sādhärana-kamma often appears in the works attributed to Dhammapāla without hesitation or any excuse. Furthermore, it is also found in the commentary by Mahānāma of the 6th century as well as in Sāriputta's works in the 12th century and even in a new sub-commentary by a modern Burmese monk. There are three points which may be made for the conclusion. 1. It is Dhammapāla who brought the concept of sädhārana-kamma from India and introduced into the tradition of Pāli commentarial literature. 2. The modifier, "of all living beings who experience the result," always added to this term emphasizes that all beings receive the result of their own actions, and thus, it does not conflict with the principal of self responsibility. 3. Sädhārana-kamma, which is not precisely defined or philosophically discussed in Buddhist literature, seems to have been used in a broad sense as it widely accepted in Buddhist society, and thus, this concept leads to the notion in modern Theravāda societies called group/collective/communal/sociokarma. 


\section{An Analytical Study of the Fourth Pārājika Rule for the Monk}

SASAKI Shizuka

The fourth Pārājika rule for monks contains an unique and unclear exemption clauses as follows. "If later on he, being pressed or not being pressed, fallen, should desire to be purified, and should say: 'Your reverence, I said that I know what I do not know, see what I do not see, I spoke idly, falsely, vainly,' he also is one who is defeated."

As a result of research focused on this phrase using Vinayas and later commentaries, the fact that this phrase was a later insertion is proved. The main conclusinons of this article are as follows.

1. The times of compilation of the Śikșāpada itself of the fourth Pārājika and of the commentary on it in the Sūtravibhanga are different.

2. As for the Śikșāpada, it was also compiled in several steps and the exemption clause above referred to is an insertion of the last step.

\section{The Hierarchy of Monks in Buddhist Samghas}

SHōNo Masanori

In the present article, we will attempt to get a glimpse of the hierarchy of monks in Buddhist samghas, assemblies of Buddhist monks, in terms of the distribution of vihäras and bowls (pātras), respectively.

The hierarchy of monks in Buddhist samghas is based on the time and date at which each member receives ordination as a monk. Thus, according to the time and date of the ordination, vihāras and bowls are distributed to the monks in a samgha. It is likely to occur that an elder monk does not receive a vihăra nor a bowl in his turn in the distribution, but a younger monk in the turn after the next receives the vihära or the bowl. Even in that case, the elder monk can grab the younger monk's vihära or bowl by requesting it three times, but then the elder monk commits a duskrtā offense. In the case of bowls, however, the description that an elder monk can grab a younger monk's bowl is characteristic of the Mūlasarvāstivāda-vinaya. 


\section{The Problem of the Record of the First Council in the Sarvāstivāda Vinaya}

INOUE Hirofumi

Although the Shisong lu (十誦律) and Genben shuoyiqieyoubu pinaiye zashi (根本説 一切有部毘奈耶雑事) are said to belong to the same sect, there are differences between these two texts. For instance, there is a difference even in the accounts of the Second Council, which is an important portion of the text for Vinaya editors. Thus, in this paper, we will indicate a difference in the First Council in these two texts. Afterward, we will examine a curious difference of the accounts of the First Council in the Shisong lu and the Da zhidu lun (大智度論), which were translated by the same translator, Kumārajīva.

\section{The Interpretation of Vinaya Based on Karma: Opinions of Theravāda Commen- taries on Crimes Made in Good Faith and Faultless}

SHImizU Toshifumi

It has never been clearly understood how the ethics of the Vinaya Pitaka, which records the regulations for those entering the monastic order, were integrated with karma-based ethics. This paper examines this question through an investigation of Theravāda commentaries and clarifies the following.

The Vinaya Atthakathā, believed to have been written by Buddhaghosa, takes no clear position on how the "ethics of the Vinaya Pitaka" are integrated with "karma-based ethics." However, Vajirabuddhi, Sāriputta, and Kassapa each take their own position on the matter.

Vajirabuddhi, the writer of the Vajirabuddhitîika, and Sāriputta, the writer of the Săratthadipani, both assert, "The ethics of the Vinaya Pitaka are determined according to laws identical to those related to karma-based ethics." However, Kassapa, the writer of Vimativinodani, declares, "The ethics of the Vinaya Pitaka are completely unrelated to karmabased ethics, as they are simply established for the management of religious organizations."

Thus, different Theravāda commentators present completely different interpretations of these ethics. The ideology of Kassapa in particular is unique in Theravāda tradition. 
64. Cetaso vikșepa, cittakșepa and auddhatya in the Jñānaprasthāna and the Mahāvibhāṣa

Nasu Yoshihiko

Sarvāstivāda-vaibhāṣikas distinguish cittakṣepa (心狂乱, disturbance of thought), cetaso vikṣepa (心乱, distraction of thought) and auddhatya (掉挙, excitedness) in Sarvāstivāda Abhidharma texts.

Cetaso vikșepa prevents a person from concentrating on one point and as a result it causes a lapse in attention. Therefore, it is opposed to samādhi (concentration). Sarvāstivāda-vaibhāṣikas maintain that because cetaso vikṣepa is a dysfunctional samādhi, however, it is essentially distinct from samā $d h i$.

Cittakșepa is a mental disorder or mental derangement caused by death of a close relative, critical illness, and so forth. Thus cetaso vikșepa is distinct from cittaksepa.

Auddhatya refers to an elevated mood or manic state. It causes a constantly active state of thought. Accordingly, auddhatya is distinct from cetaso viksepa.

For these reasons, cetaso vikșepa, cittakșepa and auddhatya are clearly differentiated in Sarvāstivāda Abhidharma texts.

\section{On the Vaibhāṣika referred to in the Abhidharmakośabhāṣya}

This paper aims to clarify Vaibhāșika (毘婆沙師) as referred to in the Abhidharmakośabhāsya. This Vaibhāṣika is the group which generally carries views based on the Vibhāsās (毘婆沙論), and accepts their authority. In Abhidharma studies, Vaibhāṣika is often identified with Sarvāstivādin (説一切有部). In this paper Vaibhāṣika in the Abhidharmakośab$h \bar{a}$ sya is clearly shown to be not only based on the Vibhạsăs, but also the essential texts of the Vibhāșās. Furthermore, according to the * Nyāyānusāra (順正理論) written by Samghabhadra, Vaibhāṣika in the Abhidharmakośabhāsya obviously states that it is only the group that Vasbandhu set up for the purpose of criticizing the theory of Vaibhāșika. Namely, when referring to Vaibhāṣika in the Abhidharmakośabhāsya, one group which professed theories based on the Vibhāṣa sand the essential texts of the Vibhạsās and another group which Vasubandhu set up for his criticism are intertwined. If the definition of the Abhid- 
harmakośavyākhy $\bar{a}$ is thought of as important, Vasbandhu might have intended some reproach and may have used Vaibhāṣika in this way.

\section{Svabhāva in the Sarvāstivāda}

Abe Shin'ya

When thinking about dharma, the relation to other various words cannot be disregarded. I consider svabhāva to be one of those relevant words, and identify it with dharma. There is an intimate relationship between svalakșaṇa and svabhāva. Both in their original languages and in translations into Chinese those terms have various forms, and the relation between them is vague. This study aims at making clear the conception of svabhāva in the Abhidharmakośabhāsya and Abhidharmanyāyānusāraśāstra. The concept may be clarified in the latter more than in the former, in which problems remain.

\section{Sanghabhadra's Vindication of the Consciousness-object Simultaneity by Means of Perceptual Awareness}

Yoshida Akira

In this paper, I will revisit the question of how Sanghabhadra defended the position of the Sarvāstivādins that each of the five sensory consciousnesses and their objects are simultaneous by having recourse to the idea of perceptual awareness (現量覚, * pratyakṣa-bud$d h i)$ in his * Nyāyānusāra. His opponent denied this simultaneity by insisting that sensory consciousness must be immediately preceded by the sense organ and its object. When the possibility of the existence of perceptual awareness of a past sensory consciousness was questioned, the opponent replied that such an awareness was possible in the same way as perceptual awareness of past feelings (受, vedan $\bar{a}$ ). As Sanghabhadra pointed out, however, perception must precede perceptual awareness, and the parallel between sensory consciousness and feeling is unestablished. In the case of experiential perception (領納現量, * anubhava-pratyakșa), feeling is simultaneous with sensory consciousness, but, according to the opponent, the sensory object is not so in the case of sensory perception（依根現量, *aindriyaka-pratyakṣa, *indriyāśraya-pratyakṣa). Therefore, it is problematic to claim that perceptual awareness of the sensory consciousness is possible in the same way as that 
of feelings. Instead, it should be argued that the object is simultaneous with its sensory consciousness, if one claims that its perceptual awareness is possible like that of feelings.

\section{On Space and Matter}

IIOKA Sachiho

According to the Abhidharmakośabhāsya space is an unconditioned element (asamskrta-dharma) as is matter (rüpa). Matter means "the cause of what is displayed." Matter is "space occupation," and creates an effect in the object of mind. The derivative form of matter (upādāya-rūpa) does not co-occur because sensory function (indriya) and that object come first, and cognitive effect comes later. Since there is no derivative form of matter, there is neither atomic matter (paramānu) nor invisible matter (avijñapti). The space which is day and night is an samskrta-dharma, and it is also the variation continuously situated at the diversity (samtatiparin̄āmaviśeșa).

According to the Abhidharmadipa, all aspects from the unconditioned element (asamskrta-dharma), the element of matter (rüpa-dharma), the mental element (citta-dharma, caitasika-dharma), to the element of no-mental disposition (citta-viprayukta-dharma) are covered.

\section{The Concept of kleśa in the Sarvāstivāda}

KIM Kyunghee

This paper examines the development of the term kleśa (煩惴) in the Sarvāstivāda by focusing on its use as a synonym for “all samyojana (結), bandhana (縛), anuśaya (随 眠), upakleśa (随煩悩), paryavasthāna (纏)," as well as the seven anuśaya (七隨眠), all of which appear separately in the Āgamas and Nikāyas but are brought together as an expression of the content of the term kleśa in Sarvāstivādin works. The first set of terms is used synonymously with kleśa as a general expression for all klișta-dharma (染污法) in the Mahāvibhāșa, while the seven anuśaya, which are taken up as the primary kleśa to be elimintated by the Sarvāstivāda, are presented as containing all three elements of the three samyojanāni (三結). Moreover, in the Samgitiparyāya, the content of drștih (見随眠), one of the seven anuśaya, is described as the "five drștayah (五見)." These aspects of the 
seven anuśaya, especially drștih and vicikits $\bar{a}$ (疑隨眠), are said to be eliminated through the cognition of the Four Noble Truths. This paper aruges that the Sarvāstivāda incorporated the seven anuśaya into their definition of kleśa because it contains these concepts.

\section{A Study of Jñeyāvarana: Akliștājiñāna in the Mahāvibhāṣā}

SASAKI Sen'yū

Although jñeyāvarana (所知障) is an important concept in the Yogācāra school, its meaning has not yet been fully elucidated. Sthiramati's commentary on the Trimsiki $\bar{a}$ explains

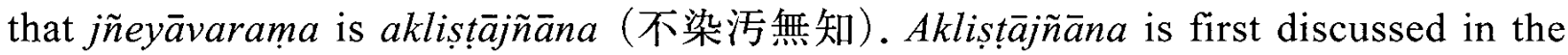
Mahāvibhāsāa. In this text, it is said that an arhat still possesses akliștājñ̄ana, but that Buddha does not. Therefore the difference between arhats and Buddha lies in whether they possess the aklistâjiñāna. In this paper, I point out that the akliștājñ̄anna was first taken up by the Sarvāstivādins in the Mahāvibhāṣā.

\section{Newly Available Sanskrit Manuscripts of Asanga's Abhidharmasamuccaya and Sthiramati's Vyākhya from the Tibet Autonomous Region}

Li Xuezhu

While the Sanskrit manuscript of *Jinaputra's commentary (Bhāsya) on Asanga's $A b$ hidharmasamuccaya (= AS) has been fully available, that of the $A S$ is hitherto known only fragmentarily. The Sanskrit manuscript of Sthiramati's $V y \bar{a} k h y \bar{a}$ has been thought to be lost.

In the present paper, I report on newly available folios from the $A S$ manuscript and those of the $V y \bar{a} k h y \bar{a}$, both of which are currently preserved in the Potala palace and Norbulingka. The facsimile copies I utilized are preserved at the China Tibetology Research Centre in Beijing.

The 11 newly available folios (fols. $1,15,18,20,23,27,29,33,39,43$, and 44) from the $A S$ manuscript originally belonged to the same bundle that includes the already known 17 folios (fols. $3,4,5,8,9,10,11,12,13,14,16,19,30,31,36,38$, and 42) of the $A S$ photographed by Rāhula Sānkṛtyāyana at Zhwa lu Ri phug in 1930s. From the fact that the last folio is numbered 44 , we know that 16 more folios (fols. 2, 6, 7, 17, 21, 22, 24, 25, 26, 
$28,32,34,35,37,40$, and 41) are yet to be found.

Furthermore, two manuscripts of the $V y \bar{a} k h y \bar{a}$ have become newly available: one consists of 215 folios (the first folio is missing), written in ca. 1156 during the Pāla dynasty, according to its colophon; and the other consists of 84 folios (about half of the folios are missing). They are now preserved in the Norbulingka.

As the $V y \bar{a} k h y \bar{a}$ contains the entire text of both the $A S$ and its $B h \bar{a} s y a$, we can now extract a complete Sanskrit text of the $A S$ from these sources.

\section{A Comparative Study of the Materials of the Śatasāhasrikā Prajñāpāramitā II: With Reference to the $13^{\text {th }}$ Subhüti parivarta}

DENIYAYE Paññāloka

For the study of the $13^{\text {th }}$ Subhūti parivarta of the Śatasāhasrikā Prajñāpāramitā II, I compared manuscripts from Lhasa (L), Kyushu University (Q) and new Nepalese paper Mss. (Tokyo University Mss. no. 382 (T1), no. 383 (T2) and Kyoto University no. 103 (K) ) with the Tibetan translation 'rab 'byor kyi le ' $u$ ' in the Shes rab kyi pha rol tu phyin pa stong phrag brgya pa (Otani no. 730 and Sde dge, Tohoku no. 8).

L, Q, T2 and K preserve the relevant text with few omissions. T1 has only a small portion of the text. L and Q, probably belonging to the $10^{\text {th }}-12^{\text {th }}$ centuries, preserve older readings that can be confirmed by the Tibetan translation. $\mathrm{T} 1, \mathrm{~T} 2$ and $\mathrm{K}$ often have similar readings. $\mathrm{T} 1, \mathrm{~T} 2$ and $\mathrm{K}$, dating to the $19^{\text {th }}$ and $20^{\text {th }}$ centuries, carry more omissions and misreadings hindering the smooth flow of the meaning.

$\mathrm{L}$ and $\mathrm{Q}$ are undoubtedly invaluable sources for future studies of the Śatasāhasrikā Praj$\tilde{n} \bar{a} p \bar{a}$ ramitā and toward a revision of the Kimura edition.

\section{A Phylogenetic Approach to Stemmatic Analysis: The Case of the Heart Sūtra in} Tibetan

IsHIDA Katsuyo

The purpose of this paper is to evaluate statistical methods of drawing stemmata. First, three major methods are introduced: (1) clustering method, (2) phylogenetic tree drawing method and (3) phylogenetic network drawing method. Previous studies on these methods 
are surveyed. Second, I apply the clustering method and the phylogenetic network drawing method to the Tibetan text of the Prajñāpāramitā-hrdaya-sūtra. From the results of previous studies and my experience, the phylogenetic network drawing method is found to be the best among the three methods.

\section{Rejection and Acceptance of the One Buddha Vehicle: The Meaning of $k$ sip in the Saddharmapuṇdarìkasūtra}

KatAYAMA Yumi

In the third chapter, the chapter on Parable (aupamya), of the Saddharmapundarikasütra (hereafter SP), the forms derived from the verb ksip-: kșipeyu (3rd pl. opt., 111), kșipi (3rd pl. opt., 118), kșipitva (gerund, 112-13, 121, 128-30), and kșipeta (past ptcpl., 135) are used in the context in which those who are unworthy to be preached the one Buddha vehicle are described. Kumārajīva (A.D. 344-413) translates the verb in this context by the Chinese word bang (謗) ('abuse, slander'), and modern scholars have given the following interpretations to the same verb:

(1) '[the fools] scorn [the law]', '[the fools] speak in dispraise of [the teaching]', '[the fools] criticize [the law preached by the Buddha]', '[the fools] laugh at [the law preached by the Buddha]' (Kern [1965], Matsunami [1982], Nakamura [1998]' Ueki [2008])

(2) '[the fools] throw away [the law]' (Iwamoto [1962])

(3) '[the fools] reject [the teaching without understanding it]' (Kubo [2006])

Where the verb kssip- is used in construction with the words for the one Buddha vehicle and the like, Kubo's interpretation of this verb as meaning 'refuse, reject' (3) is reasonable. The present paper aims at showing this.

It is important to note that, in the Upāyakauśalya chapter, one who has a belief (śrad$d h \bar{a}$ ) in the Buddha or the Buddha's words and who joyfully accepts (anumoda) the teaching of the Buddha is described as opposed to one who rejects (ksip-) the teaching. The use of the verb ksip- in this sense reflects how hard it was to accept the doctrine of the one Buddha vehicle at the time when the Saddharmapundarikasütra preached it while the doctrine of the three vehicles had already been established. Thus the meaning of the verb ksipin the given contents must be comprehended from the point of view of how the doctrine of 
the one Buddha vehicle came to be accepted in the Buddhist atmosphere of the time.

\section{The Formation of the Fushou xinming jing (佛説心明經): The Possibility of a Mahāyāna-sūtra Affiliated to the Sarvāstivādins}

HiraOKa Satoshi

This paper examines the formation of the Fushou xinming jing, one of the oldest Mahāyāna sūtras, translated into Chinese by Dharmarakșa (焱法護) in the early fourth century. This short text is, according to Masao Shizutani, classified as a primitive Mahāyāna sūtra, since it does not refer to "Mahāyāna" (大乗), but mentions the prophecy of Buddhahood to a woman who gave some food to the Buddha. There is a parallel stroy in the Mūlasarvāstivāda-vinaya: Bhaișajya-vastu (= Divyā̄vadāna chapter 4). in which the Buddha bestows upon the woman the prophecy of Pratyekabuddhahood. What are the possible relations between these two texts?

(1) The Fushou xinming jing borrowed the motif from the Mülasarvāstiväda-vinaya.

(2) The Mūlasarvāstivāda-vinaya borrowed the motif from the Fushou xinming jing.

(3) Both texts borrowed from a common pool (the two texts having no direct relation in this case).

(4) The Fushou xinming jing borrowed the motif from the Ur-text of the present Mülasarvāstivāda-vinaya (because the story in the Fushou xinming jing is much simpler concerning both the story itself and the cliche of prophecy).

There might be other possibilities, and we should not jump to conclusions. It is clear, however, that the Fushou xinming jing has, in respect to this story, a close relation to the Sarvāstivādins. In the future I will examine whether we are justified in describing this Mahāyāna sūtra as a text affiliated to the Sarvāstivādins and, more generally, whether we can ever say that a certain Mahāyāna sūtra is affiliated to a certain sect.

\section{On an Unknown Sūtra: The Kșāranadĭ}

Tsuda Akimasa

The Sattvārādhanastava, attributed to Nāgārjuna, is said to be an edition of a sūtra named * Kṣāranadī in gāthā style. There exist two other writings which cite this sūtra. 
They are the commentary of Vasubandhu on the Mahāyānasītrālamkīara and the commentary of Buddhaśānti on the Deśanāstava of Candragomin. These three texts related to the sūtra do not correspond to one another.

On the other hand, the 1177th sütra of the Za Ahan jing（雑阿含経, Taisho 99) has a metaphor of a ${ }^{*} k s \bar{a}$ ranadi (灰河). Vasubandhu cites a phrase from this sūtra in his abovementioned commentary. The other two texts, i.e. the Sattvārädhanastava and the citations in the Deśanāstava-vrtti, have no correspondence to this sūtra.

Thus we can say that there are at least three kinds of text of the Kșāranadi, that is to say, the 1177th sūtra of the Za Ahan jing, the Sattvārädhanastava and the citations in the Deśa$n \bar{a} s t a v a-v r t t i$.

We may deduce that the name Kșäranadī either refers to several sūtras that have the same title but different contents, or that it is a complex text constituted of various sūtras. As this sūtra may have been transmitted under another title, we should widely investigate other sūtras, too, in terms of their possible relation to the texts referred to in this paper.

\section{On the Formative Process of the Early Yogācāra School: Based on Asañga's Works}

\section{GōDA Hideyuki}

In this paper, I confirm from several points of view that the existence of the yogācāra (瑜伽師) connected to Asanga formed the Early Yogācāra School, and also point out fundamental differences between Asanga and Vasubandhu. On the bhāvanā theory described only in the Samdhinirmocanasütra and Asanga's works, the importance is also pointed out of the concept called "sambhinna (総)" which is characterized as an object of meditation by the yogācāra after the darśanamārga. It is closely linked also to the five aspects of bhāvanā (修習の五相), and is one of the characteristics of the bhāvanā theory in the Early Yogācāra School. However, such a description cannot be seen in the latter literature. In conclusion, the concept of "sambhinna" means that all such various individualities are collected through meditation to intuit the Dharma comprehensively. 
78. Some Questions Concerning Sthiramati's Authorship of the Sūtrālamkāravrttibhāsya

UENO Yasuhiro

The Sütrālaṃkäravrttibhāṣya (=SAVBh), preserved only in Tibetan translation, has been traditionally ascribed to Sthiramati (ca. 510-570). This is found to be questionable when the entire text is examined because of: (1) reference to the three hetus (kārya-. svabhāva-, anupalabdhihetu) employed by Dharmakirti (ca. 600), (2) reference to the neither-onenor-many proof commonly used by Śantarakșita (ca. 725-788) and later, and (3) the insertion of the phrase rgya gar skad $d u$ when transliterating a Sanskrit technical term before translating it into Tibetan, in the middle of each chapter's annotation. The two former points superficially give cause to doubt Sthiramati's authorship of the SAVBh. The third point might suggest the possibility that the translator of the SAVBh inserted the arguments mentioned in the former two points.

\section{Essence and Secondary Object-support-condition: The Early Yogācāra and Solip-} sism

Minamoto Jūkō

It is not the case that the new Yogācāra asserts "solipsism". The new Yogācāra, however, can neither disprove solipsism nor explain our daily experiences. This is because the new Yogācāra assumes the same structure of thought as that of Dharmakirti. Dharmakirti's Yogācāra view as presented in the Samtānāntarasiddhi does not assert solipsism. But it can neither disprove solipsism nor explain our daily experiences.

\section{Bodhisattvas Do Not Directly Realize Extinction: A Consideration of the Differ- ence between Bodhisattvas and Śrāvakas and Pratyekabuddhas in the Madhyamakāva- tārabhāṣya}

ŌTA Fukiko

In the first chapter of the Madhyamakāvatärabhāsya (MABh), which deals with the first stage of the bodhisattva path, Candrakirti states that bodhisattvas of this stage exceed śrā- 
vakas and pratyekabuddhas in the aspect of determination, and that bodhisattvas surpass these types of practitioners in terms of wisdom upon reaching the seventh stage. This paper examines the nature of the bodhisattva path by considering the difference between these three types of practitioners as presented in the portions of the MABh concerning the sixth, seventh, and eighth stages, as well as its depiction in sūtras preceding Candrakīrti. He states that in the sixth stage, bodhisattvas attain complete understanding that dharmas are not self (dharmanairätmya), but that the understanding of this truth by śrāvakas and pratyekabuddhas is incomplete. Concerning the bodhisattva's attainment in the seventh stage, Candrakirti says that they become able to instantaneously enter and leave a state of mind that is one with extinction (nirodha), and therefore do not directly realize complete extinction. By considering the Aștasāhasrikā prajñāpāramitā-sūtra, I show that the reason bodhisattvas do not attain this state of complete extinction is so that they will be able to conduct altruistic practices. On the other hand, śrāvakas and pratyekabuddhas do not engage in altruistic practices, are unable to instantaneously enter and leave such a state of mind, and therefore fall into extinction. Further, while śrāvakas and pratyekabuddhas enter into complete nirvāna, bodhisattvas in the eighth stage are presented as intentionally remaining in samsāra to save sentient beings. By looking at the ten bodhisattva stages presented in the MABh from this perspective, one can see that a bodhisattva's wisdom is said to be perfected in the sixth stage, and the performance of altruistic practices is held to be central to the succeeding stages.

\section{On Mahāyānābhisamaya}

TOKuSHIGE Hiroshi

Mahāyānābhisamaya, an important term appearing in such texts as the Sarvatathagatatattvasamgraha, has not yet been sufficiently studied. In this paper, I will examine the salient features of texts in which this term appears, and study examples appearing in those texts.

Besides the previously pointed out Sarvatathāgatatattvasamgraha and Adhyardhasatikāprajñāpāramitāa, examples of the term mahāyānābhisamaya occur in the Mahāvairocanābhisambodhi-tantra, Vajramandālankāra, and others. In most texts the term appears in the context of the mahāyānābhisamaya of "all the tathāgatas" (de bzhin gshegs pa thams cad 
kyi theg pa chen po mngon par rtogs pa), while in the Mahàvairocanābhisambodhi-tantra it is modified with "the bodhisattvas" (byang chub sems dpa' rnams kyi theg pa chen po mngon par rtogs pa).

Besides the Paramādya cycle and Sarvatathāgatatattvasamgraha, the term mahāyānābhisamaya is used in such texts as the Fóshuō mími sānmèi dàjiāowáng jìng (佛説秘密三 昧大教王經). In those texts, in the context of mahāyānābhisamaya used to describe Vajrasattva who has manifestly realized the Mahāyāna of all the tathāgatas, mahāyānābhisamaya is used as a descriptor for Vajrasattva, as the name of Vajrasattva's heart-mantra, as the name of a mandala centered around Vajrasattva, and so on. Accordingly, it can be conjectured that mahāyanābhisamaya is a term primarily used to symbolize Vajrasattva.

\section{Ratnākarašānti's Interpretations of Jāpa in the Mahāmāy $\bar{a}$-tantra}

ŌMI Jishō

Ratnākaraśānti (ca. 10c.-11c.), an Indian Buddhist Master who was familiar with both the pāramitānaya and the mantranaya, wrote the Gunavatī (abbr. $\mathrm{Gu}$ ), a commentary on the Mahāmāya -tantra (abbr. MMT). In the present paper, the author will examine "Recitation" (Jāpa) in the MMT based on the systems of the Guhyasamajja-tantra (abbr. GST), through an analysis of Ratnākarasaanti's interpretations of the term "[in the state] without existence and non-existence" (bhāvābhāvavivarjitam) (MMT, chap. 2, verse 3, pāda c). In his commentary on the relevant part of the MMT, Ratnākarasianti quotes the GST (chap. 11, verse 2, pāda a and pāda ef). The present author presents a new interpretation of this verse of the GST (cf. note 6 in Japanese version).

In comparison with another commentaries on the MMT, the distinctive feature of Gu's interpretations lies in the fact that it cleverly innovated the Mind-only Theory into interpretations of Jāpa practice of the MMT. It can be concluded that Ratnākarasāanti's interpretations of Jāpa in the MMT integrated, in order that a practitioner attain the "[state] without existence and non-existence," by way of interpreting two ways of meditation in Jāpa practice, "Expansion" (spharana) corresponding to "Process of Production" (utpattikrama) by uttering the sound OM and "Contraction" (samhāra) corresponding to "Process of Completion" (utpannakrama or nișpannakrama) by uttering the sound HŪM parallel with two states in the Mind-only Theory, "Mind-onlyness" (cittamātratā) and "Entering into Equal- 
ity" (samatāpatti), respectively.

Incidentally, Ratnākaraśānti interpretes the term "as soon as thought" (cintitamātreṇa) (MMT, chap. 1, verse 27) with "as soon as recited” (japtamātreṇa). For Ratnākaraśānti, therefore, to recite is just to meditate. According to the present examinations, it can be understood that objects upon which a practitioner meditates are "Mind-onlyness" and "Entering into Equality."

\section{Ratnākarasānti's Theory of pramāṇa}

MORIYAMa Shin'ya

This article aims at clarifying Ratnākaraśānti's theory of pramāna, i.e., the means of valid cognition, on the basis of his Madhyamakālañkāravrtti ad Madhyamakālañkära vv. 32 40. By using the Yogācāra terminology of trisvabhāva and Dharmakīrti's concept of pra$m \bar{a} n a$, in this section Ratnākaraśānti classifies pramāna into two types, namely, the Buddha's and bodhisattvas' wisdom of emptiness as the ultimate means of valid cognition (pāramārthikapramāna), and the conventional means of valid cognition (sāmvyavahārikapramāna).The latter is further divided into self-awareness (svasamvedana), as non-conceptual valid cognition, and inference (anumāna), as conceptual valid cognition. The study is summarized in the following diagram.

[1] pāramārthikapramāna = the Buddha's and bodhisattvas' wisdom of emptiness, which is born of meditation.

[2] sāmvyavahārikapramāna

[2.1] Self-awareness, which is non-belying (avisamvāda) with regard to the object-appearance because of its identity ( $t \bar{a} d \bar{a} t m y a)$ with the illuminating nature of cognition.

[2.2] Inference, which is non-belying with regard to the object that is determined as 'particular entity,' because of its causal relation (tadutpatti) to inferential cognition, and which reveals objects that have not been apprehended.

\section{[3] apramāna}

[3.1] Sensory cognition that has no identity with an external object.

[3.2] Recollection and conceptual cognition preceded by perception, which are non-belying with regard to their objects, and which grasp objects that have already been grasped. 


\section{Dharmottara's Interpretation of the Causelessness of Destruction: With gTsang nag pa's Commentary on the Pramānaviniścaya}

CHor Kyeong-jin

Dharmottara (ca. 740-800) articulates a unique understanding of the vināśtivānumāna in his commentary (PVinT) on the Pramanaviniścaya. He interprets the causelessness of destruction (ahetutva), which is a valid proof of vināsítvānumāna, as an assistant (parikara) to the sādhyaviparyaye bädhakapramāna (a valid cognition which negates the logical reason's occurrence in what is incompatible with its object to be proven, henceforth: $b \bar{a} d$ hakapramāna). The text's discussion begins with an opponent's objection: non-momentary things are causally efficacious (arthakriy $\bar{a}$ ) like a pot which is destroyed by means of a hammer acting as a cooperating cause (sahakäripratyaya). Dharmottara's refutation of this objection, which leads up to the justification for insisting on the assistive function of the causelessness of destruction, is divided into two parts. But one can hardly decipher what Dharmottara specifically aims to refute among the objections and asserts through his own rejoinder. With that said, gTsang nag pa's (12c.) interpretation of Dharmottara's concept of the causelessness of destruction in his commentary on the Pramānaviniścaya, rNam nges Legs bshad bsuds pa, may offer some guidance. He writes that in Dharmotarra's refutation of his opponent's example, the concept of the causelessness of destruction makes clear the parkșadharma of the bādhakapramāna. Similarly, the vyäpti of the bädhakapramāna becomes clear through his refutation of his opponent's logical reason (hetu). The aim of this paper is to attempt to understand Dharmottara's interpretation of the causelessness of destruction found in the argument between Dharmottara and his opponent using gTsang nag pa's analysis.

\section{On the Writings of Ma cig Lab kyi sgron ma}

NishioKa Soshū

Ma cig Lab kyi sgron ma is one of the most renowned Tibetan women saints, and founded the gCod school in the 11th century. As for her writings, "some kinds of $b K a$ ' tshom" which are genuine are mentioned in the dPag bsam ljon bzang (fol.238b3), bKa'tshom chen mo, Yang tshom le'u nyer lnga pa, Le'u yan lag brgyad in Shes bya kun khyab (Vol. 
om, fol.192b5-6) and bKa' tshoms chen mo, Yang tshoms chen mo, Nying tshoms chen mo in Zhi byed dang gcod yul gyi chos 'byung (fols.68b6-69a1). From the description above, it is known that she was responsible for writings called "some kinds of $b K a$ 'tshoms" (i.e. bKa' tshoms, Yang tshoms, Nying tshoms) and Le'u yan lag brgyad. This paper examines the contents and colophons of these four writings, collected in the gDams ngag mdzod (Delhi edition, Vol.9; Paro edition, Vo.14) and offers a summary. Moreover, it examines the relations between these writings and the gCod Collection (Toyo Bunko, No.50-756766) brought from Tibet by Rev. Kawaguchi Ekai.

\section{The Position of Ganacakra in the Compendium of Tantra by Grags pa rgyal mt-} shan

SHIzUKa Haruki

This paper examines the relationship between the two manuals of ganacakra composed by two masters of the early Sa skya school, Sa pan and his direct master Grags pa rgyal mtshan, and the Jeweled Tree Compendium of Tantra (rGyud kyi mngon par rtogs pa rin po che'i ljon shing), a masterpiece of Grags pa rgyal mtshan's writing supposedly composed in the process of the domestication of Indian Vajrayāna Buddhism in Tibetan Buddhist circles. First, I present a comment of Sa pan on Grags pa rgyal mtshan's manual of 'medium length' ganacakravidhi, following the presentation of the synopses of two manuals. Next, in order to show the position of ganacakra in the grand map of Vajrayāna, I present a synopsis of 'the samaya of eating and drinking' which constitutes a part of the above-mentioned writing. Since the author identified the term ganacakra with 'the specialized samaya of eating and drinking,' it becomes clear that this Sa skya pa master considered the position of ganacakra as being rooted in samaya which is the Vajrayāna version of silla, being one element of 'the three types of learnig' (tisrah sikșāh) functioning throughout all of Buddhism, and performing ganacakra was an obligation for Vajrayāna Buddhists.

\section{Klong chen pa's Image of Vimalamitra}

YASUDA Akinori

Vimalamitra (ca. the $2^{\text {nd }}$ half of the $8^{\text {th }}$ to the $1^{\text {st }}$ half of the $9^{\text {th }}$ century), who was invited 
from India to Tibet, plays an important role in the earlier spreading of the Dharma in Tibet, and is regarded as one of the founders of the rNying ma school. He is mentioned in different ways by Klong chen rab 'byams pa (1308-1363), the greatest thinker of the rNying ma school. 1. Vimalamitra is described in the chronicles as one of the great rDzogs chen masters through his various activities. 2 . Klong chen pa directly refers to him in his prayers, characterizing him by his moral qualities. 3. In sādhanas Vimalamitra is clearly visualized in meditation and understood as a concrete living being through visionary phenomena. 4 . Klong chen pa sees Vimalamitra as an incarnation of his most important teacher, Kumarāza (1266-1343), arguing that the latter has transmitted the rDzogs chen texts, Bi ma snying thig, which are attributed to Vimalamitra, to him, and that the prediction of Vimalamitra's reincarnation is found in the text $r$ Dzogs pa chen po snying tig gi lo rgyus chen mo.

\section{The Nine Stages of Mental Abiding in 'Jam dbyangs bzhad pa's "Great Expositon of the Concentrations and Formless Absorptions"}

In the dGe lugs pa tradition of Tibetan Buddhism, concentrations (bsam gtan, dhyāna) and formless absorptions (gzugs med kyi snyoms 'jug, ārūpyasamāpatti) form a subject to be dealt with in a course of lectures and to be debated in monastic education. "Great Expositon of the Concentrations and Formless Absorptions" (bSam gzugs chen mo, SZCM) by 'Jam dbyangs bzhad pa (1648-1721) is a textbook (yig cha) on this subject, which is used in the Gomang monastery in Drepung.

SZCM discusses the above-mentioned subject on the basis of Tsong-kha pa's Lam rim chen mo, the Śrāvakabhūmi, the Abhidharmasamuccaya, and the Samahinirmocanasūtra, etc. It is interesting that these texts use the same term in different senses, and hence in some cases may cause unnecessary confusion. The aim of this paper is to show how SZCM avoids such confusion regarding terminology, by focusing on the use of the term zhi gnas (śamatha, 'calm abiding').

SZCM posits two kinds of concepts of zhi gnas: one which fits the definition of zhi gnas (zhi gnas mtshan nyid pa); the other which resembles zhi gnas (zhi gnas rjes su mthun pa). They are also respectively called zhi gnas in itself (dngos) and nominal zhi gnas (btags). In addition, SZCM posits another concept of zhi gnas: what is classified as zhi 
gnas (phyogs). Both zhi gnas as fitting its definition and zhi gnas as something similar to it are subsumed under what is classified as zhi gnas. It is to be noted that the zhi gnas SZCM refers to as what is classified as zhi gnas is treated simply as nominal zhi gnas by LRCM. SZCM is a textbook, so it has to give an accurate idea of a technical term used in the relevant texts.

\section{Three Works on Newar Buddhism Published Recently in Japan}

\section{YoshIZAKI Kazumi}

Three interesting works on Newar Buddhism were published in the last few years in Japan.

(1) Yamaguchi Shinobu, Nepāru Mikkyō Girei no Kenkyū (A Study of Newar Buddhist Rituals), Sankibo Bussho-rin, Tokyo, 2005: In this book, the author, Ms. Yamaguchi, translated a text of Newar Buddhist ritual into Japanese, namely, Ratna kājī Vajrācārya ed., Kalaśārcana-pūjā-vidhi [Kalaśa-pūjā], (Newar Buddhist Sanskrit Text, no.1, Kāntipur, N.S. 1108, V.S. 2045, A.D.1988). Ratna kājī's text was published to construct a new system of Kalaśa-pūjā, the principal ritual in Newar Buddhism. The new system was established along with the worship of Cakra-samvara Tri-samādhi. Although Yamaguchi translated the text, she does nothing to explain its intent. This new system has not yet been accepted in Newar Buddhist society, although it may be in common use in the future.

(2) Tsutsumi Rika tr., Shaka zoku, Tokuma Shoten, Tokyo, 2009 (Ajaya Kranti Shakya, The Śăkyas, Nepal Buddhist Development \& Research Centre, Kathmandu, 2006): Among Newar Buddhists, Vajrācārya priests hold an important position in daily life by officiating at many rituals for their clients. But Sākyas have less opportunity to act as spiritual leaders in Newar Buddhist society. In this condition, one young Śākya, Ajaya Krānti, wrote a book to seek their identities as Buddhist monks. Although it is hard to say that his attempt resulted in success, the book written in English shows us one of the most serious problems that confront them. And being translated into Japanese, Buddhists in Japan now have a chance to deepen their mutual understanding with Sāakyas in Nepal. 
(3) Yamaki Yuko ed., Paubha Painting in Nepal, Fukuoka Asian Art Museum, Fukuoka, 2011: Newar religious paintings (Paubhās) have a world-wide reputation. Painters from different castes execute autographed Paubhās in compliance with collectors' requests. In the old days, Paubhās were executed only for a religious purpose by artisans from specified castes. The possibility of secularities was excluded completely in these traditional Paubhās. But at the next stage, Paubhās were executed to commemorate some religious activities among Newar Buddhists, and the name of donors were often recorded in inscriptions. Although secular elements were added in these Paubhās, they were still sacred. Thus they were celebrated by rituals upon their completion. On the contrary, modern Paubhās do not always receive such rituals. There are many differences between modern Paubhās and traditional ones. They offer good clues to consider Newar cultural history.

\section{Near Rhymed Gäthās and Conditioning Factors in Chinese Buddhist Scriptures}

SArTō Takanobu

In the $g \bar{a} t h \bar{a} s$ of Chinese Buddhist Scriptures, there are perfectly rhymed gāth $\bar{a} s$ as are found in Chinese traditional literary works, and also near rhymed gāthās as are found in popular literary works. The phenomenon has several factors. In this paper, I classify those gäthās into 5 categories by the conditions of rhyme: 1 . rhymed gāthās, 2. near rhymed gāthās, 3. supposition of near rhymed gāthās, 4. lost rhymed gāthās, 5. unrhymed gāthāa. I survey near rhymed gāthās and supposition of near rhymed gāthās. In addition, I classify the factors into 4 categories, and verify each factor: 1 . limit of linguistic ability of Buddhist priests coming to China from India and Central Asia, 2. mis-transcription, 3. region of their Chinese acquisition, 4. respect for original theory in sütras. In this way, we understand that translators and authors were concerned about rhyme in $g \bar{a} t h \bar{a} s$.

\section{Five Elements into Context to Disease as the Object of Contemplation in the}

\section{Mohe Zhiguan}

WATANABE Yukie

The traditional ordering of the Five Elements theory is wood, fire, earth, metal, water (coordinated with the Five Viscera as liver, heart, spleen, lungs, kidneys). But in the con- 
text of disease as the object of contemplation in the Mohe Zhiguan, the order is wood, fire, metal, water, earth (coordinated with the liver, heart, lungs, kidneys and earth). Earth (spleen) must be placed in the center. In brief, earth of the Five Elements in the context of disease as the object of contemplation is at the tail of the procession. This shift is not random. Here I discuss the characteristics of Zhiyi's presentation of the Fire Elements.

\section{On the Formation of the Pŏphwa chong'yo}

KIM Byung-kon

Wŏnhyo's 元暁（617-686）Pŏphwa chong'yo 法華宗要 is the first commentary to the Lotus Sutra written on the Korean Peninsula. We can determine the level of Lotus Sutra studies of those days on the Korean Peninsula through this book.

I am working on a translation-and-commentary of this book, the first in history, using the only extant manuscript of this book in the Ninnaji Temple 仁和寺 in Japan.

I will demonstrate in this paper three points based on the results of my research.

First, I consider and clarify the structure of Hwajaeng 和猙 (harmonizing disputes) in this book to clear up the theory of Hwajaeng.

Secondly, although two opinions about the Lotus Sutra are being opposed to each other, I point out that the conventional views over the opinion of the first masters 初師 among the two are unsuitable.

Thirdly, I clarify that this work dates to the year 668, which was unknown until now.

\section{Changes to the Signature of Nichiren (日蓮) on Handwritten Documents and Copies of the Gohonzon (御本尊): On the So-called One Hundred Sado Island Gohonzon}

WAKAE Kenzō

It is recorded that during his stay on Sado Island between the 10th month of the 8th year of Bun'ei (1271) and the 3rd month of the 11th year (1274), Nichiren inscribed 100 Gohonzon. At present six of these are said to exist. However, they are undated.

Nichiren wrote many personal letters and Gohonzon, signing each either at the end of the text or at the bottom of the page. Until the 6th month of the first year of Kōan (1278) he signed with the letter ban (vam), while from the 7th month onward he wrote the letter bo- 
ron $($ bhru $\dot{m})$. It is possible to determine when letters were written by observing the change in writing in the anusvāra. This leads to the following results:

On the whole, the change in signature on Gohonzon reflects that in the personal letters.

The change in signature on the Gohonzon is not as extreme as that in the letters.

The so-called One Hundred Sado Island Gohonzon were not written while Nichiren was on Sado, but rather inscribed after he entered Mt. Minobu in 1274. This can be determined from the fact that the anusvāras in these signatures are very long, which dates them to after the 11th year of Bun'ei.

\section{An Analysis of Photographs Left by Japanese Buddhist Priests Visiting Tibet dur- ing the $1900 \mathrm{~s}-1920 \mathrm{~s}$}

Ко̄мото Yasuko

Photographs taken in Tibet between the end of the 19th century and the beginning of the 20 th century are an extremely valuable record of Tibet. In those days, whether Tibetan or foreigner, very few people were able to take photos in Tibet. In Europe and in the United States, classification and analysis of these photos has already been started, such as the project by the British Museum and the Pitt River Museum, "The Tibet Album: British Photography in Central Tibet 1920-1950." But though several Japanese entered Tibet and brought back many photos of Tibet at that time, very little research has been done on their photos.

Aoki Bunkyo's materials are regarded as the most famous collection, known as superior both in quality and quantity compared to photo collections taken by other Japanese. These have already been described in two articles, "An Analysis of the Image of Tibet in Accounts of Japanese Buddhist Priests in the Meiji-Taisho Era," "An Analysis of Early-20thCentury Photographs of Tibet Taken by Aoki Bunkyo, a Japanese Buddhist Priest."

Based on these analyses mentioned above, this study will analyze two other old collections of Tibetan photos. One is included among Tibetan materials in the collection of Kawaguchi Ekai, possessed by Tohoku University. The catalogue of Kawaguchi's materials has been published, and much has been written on those materials, except the photographs. The other one belonged to Tada Tokan, kept after his death by Kitamura Hajime, who studied Tibetan language under him. The aim of this research is to examine the photos belonging to these two collections in order to clarify their material significance as a record 
of Tibet.

\section{Kiyozawa Manshi's Definition of the Soul as the "Apperceiving Substance": The Influence of Rudolf Hermann Lotze}

Bernat MarTi-Oroval

This paper analyses Kiyozawa Manshi’s 清沢満之 definition of the soul, expressed in the Skeleton of a Philosophy of Religion (宗教哲学骸骨), which considers it as 'the apperceiving substance.' Although a few scholars have pointed out the influence of Western philosophy upon Kiyozawa's idea of the soul, none have given attention to Tachibana Senzaburo's 立花銑三郎 review of the Skeleton published in 1892. In this review, Tachibana indicates that Kiyozawa's theory of the soul bears a resemblance to that of Hermann Lotze. With an awareness of this remark, I compare Kiyozawa's definition of the soul with that exposed in the third part of Lotze's Metaphysics. My conclusion is that both Kiyozawa and Lotze share similar opinions on the nature of the soul. As a matter of fact, they regard the basic characteristic of the soul as consciousness, and deduce the unity of the soul from it. Furthermore, both of them, opposing the materialistic approach that denies the existence of the soul as an independent entity, try to demonstrate that the soul is emancipated from the physical dimension. Additionally, it is noteworthy that they give a peculiar meaning to the term 'substance' in a similar way.

\section{Hunt and the Formation of the Shin Buddhist English Service Book}

KIKUCHI Masumi

The overseas propagation of Jōdo Shinshū Hongwanji-ha (Nishi Hongwanji) has a long history, and consists of four main districts, "Buddhist Churches of America" (founded in 1899), "Honpa Hongwanji Mission of Hawaii" (founded in 1889), "The Jodo Shinshu Buddhist Temples of Canada" (founded in 1905), and "The South America Hongwanji Mission" (founded in 1955). However, it has become necessary to discuss re-constructing the English Shinshū doctrine. As I was an overseas minister in Canada for six years, I have personally experienced these challenges, and in an attempt to resolve them, I am now conducting research on "Shinshu Doctrine in America." 
As a part of my research, this paper explores the process of the transformation of the Jōdo Shinshū's doctrine in America by examining the ritual section of the first Jōdo Shinshū Hongwanji-ha English service book Vade Mecum (published in 1924), and the role of its editor, Ernest Hunt (1878-1967), who was a European ordained priest in Hawaii. Vade Mecum is still influential among English speaking Shin Buddhists and its format is currently used in English services.

\section{The Representation of India in Gotenjiku 五天竺}

ISHIZAKI Takahiko

Traditionally, the Japanese divided the entire world into three parts, namely, Honchō (本 朝) (Japan), Kara or Tō (唐) (China), and Tenjiku（天竺）（India）. In the early eighteenth century, as new knowledge about world geography was introduced to Japan, this understanding, known as Sangoku-Sekaikan (三国世界観), gradually declined, and a new understanding called Godaishu developed. However, Sangoku-Sekaikan did not decline immediately after the introduction of Godaishu. Moreover, it is unclear whether this kind of progressive approach infiltrated into the ordinary people in early modern Japan. For instance, Gotenjiku 五天竺 is a ningyō-jōruri work of the poppet theatre that first appeared on stage approximately one century after the Godaishu concept was introduced. We observe that the name of this work is 'Gotenjiku' (literary five-Tenjiku) and that SangokuSekaikan and the word Tenjiku still appeared in indications of the places of stories and within them. Although Gotenjiku has been studied in theatre history and Chinese literature, it is possible to reconsider this work in terms of the way Japanese people saw the world. By studying the work Gotenjiku, this paper examines Japanese recognitions of the world and presents the representation of India that was accepted by the ordinary people in early modern Japan.

\section{Shinran's View of the Cosmos and Revaluation of Shumisengi}

NABEshima Naoki

Buddhist cosmology reflects the ancient Indian view of the universe and of time, embraced by the Buddha's compassion. Explanatory diagrams of the Buddhist cosmos 
(shumisengi 須弥山義) visually represent this Buddhist astronomical reflection. In this paper, I would like to clarify Shinran's view of the cosmos and Amida Buddha. I would also like to revaluate the significance of the Shumisengi that were created to present as Buddhist cosmology and as calendars in the $19^{\text {th }}$ century.

\section{The Relationship between the Chapter on Easy Practice and Shinran}

KuWAHara Akinobu

The Commentary on the Ten Bodhisattva Stages [Skt. Daśabhümi-vibhāṣa-śāstra] was written by Nāgārjuna [ca. 150-250.] This commentary is an annotation on the Sütra of the Ten Stages [Skt. Daśabhūmika-sūtra], and quotes and refers to some original Mahāyāna texts which explain the bodhisattva's practice. The main source of quotations for Shinran [1173-1263] in his Chapter on Practice of The True Teaching, Practice and Realization of the Pure Land Way is the Chapter on Easy Practice, the 9 chapter, of this commentary. This paper clarifies the relationship between the Chapter on Easy Practice and the intention of Shinran's quotations.

In chapters 6 to 11, the main topic is the concrete way for bodhisattvas to practice to attain the stage of nonretrogression. Through this commentary, the key word is "strong heart" to accomplish the bodhisattva practice, and all practice is based on the virtue of the heart. In the Chapter on Easy Practice, the practice is the "easy practice of entrusting," reciting Buddhas' names with reverent heart.

According to the original text, reciting Amida Buddha's name is one of the practices, which is regarded as "easy practice of entrusting" in the Chapter of Easy Practice. The main point of this easy practice is the heart or entrusting, and therefore they have the effect of praising physically, verbally and mentally.

However Shinran changed the reading order, and separated Amida Buddha from other Buddhas and emphasized his praise for Amida Buddha. The recitation corresponds to Shinran's implication, which signifies the true understanding of the Practice. Shinran defines the core of Mahāyāna bodhisattva practice, in which self-benefit and benefit of others have been perfectly fulfilled, by these quotations. 
100. The Sources of the Zonkaku hōgo

TAtsuguchi Kyōko

Zonkaku 存覚 (1290-1372) was a great-great-grandchild of Shinran 親耀, the founder of the Jōdoshin sect. He devoted his life to the expansion of the religious community of the sect. He wrote many books of the request of Jōdoshin priests. The Zonkaku hogo 存覚法 語 was one of them. At the request of Kaien zenni 契縁禅尼, Zonkaku wrote the Zonkaku $h \overline{o g o}$ in 1356. This book is different from others because it was written for a woman.

In this paper, I indicate the sources of the Zonkaku hoggo, among which are technical as well as literary works.

For that reason we can conclude that Kaien zenni was an aristocrat and had a mastery of Buddhism.

\section{Zonkaku（存覚)'s View of Religious Guides}

Kuroda Yoshimichi

In historical studies of Jōdo Shin Buddhism, shi (師: master) and zenjishiki (善知識: good/true leader, or originally 'good friend who guides one to the Teaching through expedient means') have often been confused with each other. Indeed, both of them are refered to as 'real religious leader,' yet the terms are, literally, different from each other: In my opinion, Shinran（親㝈: 1173-1262） and Kakunyo（覚如: 1270-1351）shared the viewpoint that the terms differ.

Zonkaku (1290-1373) also basically had the same idea. However, from the view-point that both of shi and zenjishiki lead us through the same path to salvation through Amida Buddha's Other Power teaching, he seems to have confused them. Generally speaking, when the "succession of the teachings" is mentioned, shi is used. However, Zonkaku often used shi and zenjishiki together. This is Zonkaku's original view-point on zenjishiki.

In addition, Shinran used zenjishiki based on the practitioner search, while Zonkaku considered zenjishiki objectively: in this respect, Kakunyo shared the same view-point. 


\section{Expression of shinjin in Shin Buddhism: Criticism of Rennyo's Faith}

Masui Yūko

Rennyo talked about impermanence many times.

Some people criticized him. I think Rennyo knew it was important to talk about impermanence to get shinjin.

\section{Shinshū Proselytizing Learning from the Structure of "Ofumi" and "Kō"}

\section{Kamo Junjō}

“Ofumi (御文)" and “Kō (講)" are structures of the missions which were developed by Rennyo, and they have contributed to expanding the religious community of the Hongwanji. They had various important functions and were excellent in terms of the method of mission. Furthermore, they have promoted the diffusion of the faith of Shinshu as a structure which mutually complements their functions in a unified manner.

\section{The Interpretation of 'Shishin Gobon' in Genshin's Rokusokugi-Shiki}

YANAGISAWA Masashi

In Tendai doctrine, there is a problem about the stage at ascetic practices called 'Shishin Gobon' (四信五品, four stages of faith, five stages of practice). Genshin argued about this subject, offering his personal opinion in his Rokusokugi-Shiki, and he tried to interpret several inconsistencies of Tiantai doctrine concerning the 'Sishin Gobon.' Kakuchō, a pupil of Genshin, revised his Rokusokugi-Shiki. While respecting, Genshin's opinion, he adopted the resists of debates in treating the 'Shishin Gobon.' So we understand how Genshin's opinion was received through Kakuchō's understanding.

\section{Shōshin's Views on True Characteristics}

\section{Matsumoto Tomomi}

"The theory of true characteristics 実相論" is a technical term used to describe the understanding of the true aspect of all existing things and forms the basis of Tiantai doctrine. 
The term is also fixed to express one field of studies on doctrine. However, compared to the accumulation of studies on the Chinese Tiantai, that of Japanese Tendai has not yet progressed so far.

From the standpoint of Shōshin's doctrine, I focus here on his views on the theory of true characteristics: the relation of the perfect integrated threefold truth 円融三諦, as well as interpenetration 互其's meaning in view of the interpenetration of the ten realms 十界 互具 will be examined to clarify the significance of the theory of true characteristics.

Although Shōshin states two logical sequences, non-dual 不二 and dual 而二, to argue the relation of the perfect integrated threefold truth 円融三諦, he put emphasis on the latter that stands for madhyama-pratipad. As for the interpenetration of the ten realms, he puts stress on the understanding that nine realms rest in the interpenetration of principle 理 具, and the interpenetration of phenomena 事具 is limited to the buddha realm only. What is common in these arguments? The answer is: the way Shōshin severely interprets their mutual differences in order to stipulate a conception. Nevertheless, the non-duality of the true characteristics is nothing but the premise, which fact has been overlooked by former studies. When Shōshin set forth an argument of two logical statements, no matter which one is more emphasized, we must pay attention to the meaning of both statements to systematically understand it.

\section{Kūkai's View on dharma-kāya}

SATō Toshichika

Some hold the position that the Dharmakāya Buddha preaches, while others deny this, holding that he only manifests himself in accordance with the capacity of sentient beings. Kūkai views Esoteric Buddhism as the teaching of the Self-oriented (jijuyō), the Dharma nature (hosshō) Buddha's innermost spiritual experience. Kūkai presents the Self-oriented Body to express that it has form, whereas the Dharmakāya in Exoteric Buddhism lacks form.

Kükai quotes the Lankāvatāra Sutra as the source of "Preaching of the Dharmakāya Buddha (hosshin seppō)." It is important to show not only the passage of the preaching of the Dharma Buddha (dharmatā Buddha), but also of the preaching of the Dharma Buddha, the Outflowing Buddha (dharmatā nisyanda Buddha). It is clear that the latter is connected 
to the former.

Kūkai quotes the Esoteric Vajraśekhara Sutra in The Difference between Exoteric and Esoteric Buddhism (Benkenmitsu nikyō ron) and also grasps Esoteric Buddhism as the teaching of the Absolute state (jishō), Bliss or Participation (juyō) Buddha. He replaced two kinds of Body with the Absolute state Dharmakāya (jishō hosshin) in The Precious Key to the Secret Treasury (Hizo hōyaku). He also quotes the Self-oriented Buddha in the Shengwei jing (聖位經) and adds the Absolute state Body in front of the Self-oriented Body. The Dharmakāya theory constituted by him has two aspects. Therefore the Absolute state Dharmakāya has two aspects, as well.

\section{The Theory of Shukuzen in Dōhan's Teiōshō}

\section{Chiba Tadashi}

In this paper I examine the Pure Land thought in Dōhan's 道範 (1179-1252) Teiōshō 貞 応抄 (1242). Dōhan was a monk of the Shingon school, active on Mount Kōya. He established the practice of himitsu nenbutsu 秘密念仏, an esoteric interpretation of nenbutsu. In my analysis I use the theory of shukuzen 缩善 of the Japanese Pure Land tradition. According to this theory, one's former lives are a root of merit. In Japan this theory was first mentioned by Genshin in his $\bar{O} j \bar{o} y \bar{o} s h \bar{u}$. In this work the theory of shukuzen explains the shukuzen kaihatsu 宿善開発. The theory of shukuzen describes the necessary conditions for rebirth in the Pure Land of Perfect Bliss. In the Middle Ages, many monks argued about this theory. Dōhan as well as other Shingon monks considered shukuzen as the ability to attain sokushin jōbutsu, buddhahood in this very body. Dōhan also adopted the theory of shukuzen in his Shōbōgenzō. Moreover, this theory was also actively discussed in the Jōdo school and Jodoshin school. Therefore, I argue that the theory of shukuzen was an important doctrine of medieval Japanese Buddhism.

\section{The Formation of the Mandala of Double-Headed Aizen}

Kagiwada Seiko

The mandala of the Double-headed Aizen (Ryōzuaizen-mandara 両頭愛染曼茶羅) is a unique religious image that continued to be reproduced throughout the Middle Ages, whose 
central figure is a unification of Aizen (愛染) and Fudō (不動). In recent years, this mandala has been interpreted as representing Aizen's fundamental vow of blissful merging (kyōai honzei 敬愛本誓) and explained as a heretical depiction of a sexual act. According to "The Teaching of the Double-Head Aizen" (ryōzuaizenhō 両頭愛染法 [a possession of the Jimyoin Temple (持明院)], however, this mandala is an iconographical representation of the visualization that occurs in the ritual of the Double-headed Aizen (ryōzuaizenhō), and the Double-headed Aizen is a figure that symbolizes the non-duality of the Matrix (taizo 胎蔵) and Diamond (kongo 金剛) Realms. By examining the relevant literature of the Heian period, we may can see that the Double-headed Aizen was respected as a representation of non-duality since that time. In addition, we hypothesize that the mandala originated in the Ono lineage (onory $\bar{u}$ 小野流), and especially in the Sanbōin lineage (sanbōinry $\bar{u}$ 三宝院 流) at Daigoji Temple (醍酤寺). In short, the Double-headed Aizen was not merely a sexual figure, but instead a central representation of the non-duality of principle ( $r i$ 理) and wisdom ( $c h i$ 智).

\section{Relationships between Parents and Children in $\bar{O} j \bar{j} d e n$ (往生伝, Accounts of Birth in the Pure Land)}

TANAKA Yūko

This paper examines the relationships between those who have passed away and been born in the Pure Land (往生人, J. ojōnin) and their families in Chinese and Japanese accounts of birth in the Pure Land (往生伝, Ch. wangsheng zhuan; J. ojjoden) from the seventh to twelfth centuries. These accounts follow the lives and deaths of various ojoonin and describe scenes in which their parents, children, or spouses nurse and assist them in their practice, and later become witnesses to their deaths/births into the Pure Land. This paper also explores the idea of "filial piety in regards to death/birth in the Pure Land" as explained in the Meditation Sutra on the Buddha of Infinite Life (観無量寿経, Ch. Guan wuliangshou jing; J. Kanmuryōju kyō), the Supplement to the Compendium of the Land of Bliss (楽邦遺稿, Ch. Lebang yigao; J. Rakuho ikō), and other sutras and contemporaneous Chinese Buddhist writing, as a backdrop to children helping their parents attain birth in the Pure Land. 


\section{The Function and Position of Faith in Hōnen's Nembutsu Thought}

Hōnen teaches that to be born in the Pure Land, both our mind and practice must be in concert. We can enter the Pure Land Gate by believing in the Essential Vow for birth in the Pure Land through the recitation of the name of Buddha Amitābha. And Nembutsu is settled as the causal karma of birth in the Pure Land by unshakable faith in Ōjō (rebirth). But the mind of the common man is easily distracted. So, we should recite the name of Buddha Amitābha continually to prevent corruption.

\section{The Saikyō-ji Collection: Its Value for Buddhist Studies}

OkITsu Kaori

The Saikyō Monastery 西教寺, situated in Bunkyō-ku, Tokyo, and affiliated to the Jōdō Shin School, Hongan-ji Sect, is home to a collection of manuscripts of Buddhist scriptures and texts, various documents, letters, and relics gathered over the centuries by successive abbots going back to Ekai Chō'on 慧海潮音 (1783-1836), Eighth Abbot of the Monastery. It comprises four basic categories: (1) Buddhist scriptures and texts; (2) historical documents; (3) literary writings such as Chinese classical poems and Japanese classical poems; and (4) other fragments. One of its main characteristics is that the majority of these manuscripts were copied or gathered by Ekai himself.

The Saikyō-ji Collection contains materials which already attracted considerable attention in the time of Ekai, and ever since researchers have continued to discover many valuable sources. Amongst the recently found manuscripts, the $\bar{O} j \bar{o} k \bar{o} s h i k i$ 往生講式 provides new information for the understanding and historical background of this text. This is the subject of my paper, and I hope that my presentation of this new discovery will also add a further proof of the value of the Saikyō-ji Collection for Buddhist studies. 


\section{On Woodblock-printed Versions of the Ketsugishōjikitetsu 決疑鈔直牒 by Shōgei 聖闾}

Minami Hironobu

This paper examines woodblock-printed versions of the Ketsugishojikitetsu written in Ōei 応永 3 (1396) by Shōgei (1341-1420), and clarifies how widely they circulated. Extant versions of the text are limited to those published after the Edo 江戸 era (the $17^{\text {th }}$ century).

By close examination of these versions, we can safely say that the content of the Ketsugishojikitetsu was fixed at the time when publishing activities flourished and the priest-training organization (Danrin 檀林) was on its way to development.

\section{Relations between the Lotus Sutra Buddhism of Nichiren and Esoteric Buddhism}

\section{SEKIDO Gyōkai}

Nichiren (1222-82) is known for having established a creative Buddhism which made the Lotus Sutra the center of its doctrine. At the same time, some point out the influence esoteric Buddhism had on his thought. That he copied works related to the esoteric Buddhism and made a vow to Ākāsa-garbha Bodhisattva during his student days are cited as reasons.

Moreover, the similarity of the Mandara of Nichiren and that of esoteric Buddhism, the acceptance and criticism of Tōmitsu (the esoteric Buddhism of Shingon) and Taimitsu (the esoteric interpretations elaborated within Japanese Tendai), quotations related to eso-

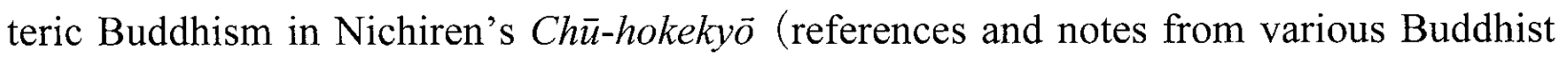
texts into the margins and on the reverse side of the document in his Lotus Sutra) are cited.

However, I think that this relation represents a transitional stage of Nichiren Buddhism. He surmounted the experience of his persecution, and raised his consciousness as a propagator of the Lotus Sutra. As a result, Nichiren absorbed the doctrines of various types of Buddhism which he had studied since his student days, and transcended them. Thus, he established a creative Lotus Sutra Buddhism. Esoteric Buddhism is one of those doctrines, and it isn't suitable to put emphasis on the relation between the special character of his Buddhism and Esoteric Buddhist thought. 


\title{
114. On Nichiren's Doctrine of "Honji-Shakuchu (本地迹中)": The Relationship be- tween the Kanjin honzon shō and the Kaimoku sho
}

\author{
Miura Kazuhiro
}

The expression "more than fifty years" occurs three times in the Kanjin honzon shō. Regarding this expression, there is a difference of opinion as to whether it refers to the whole period of the Buddha Sākyamuni's teaching, or to the period of the forty and more years that excludes the period of eight years in which he preached the Lotus Sutra. Kariya Nichinin supported the first view. He argued that apart from the Lotus Sutra taught by the Buddha Śăkyamuni, there also existed the Original Lotus Sutra taught by the Eternal Buddha, and that the former corresponds to the shakumon and the latter to the honmon of the present Lotus Sutra. His theory supplements the interpretation of Nichiryū.

A similar expression is found in the Kaimokusho: "Abandon the sutras preached before the Lotus Sutra, the honmon and shakumon of the Lotus Sutra and Nirvana Sutra, and emphasize Chapters 15 and 16 of the Lotus Sutra." In this context we should understand that the honmon to be abandoned is the honmon of the Lotus Sutra taught by the Buddha Sākyamuni, and the two chapters mentioned above constitute the honmon of the Original Lotus Sutra.

Since the Kaimokushō emphasizes the cause of enlightenment, these two chapters are singled out. Conversely, the reason why all of the eight honmon chapters are highly regarded in the Kanjin Honzon sho is because the focus of this latter work is the transmission of the Title of Lotus Sutra that is the Teaching itself.

\section{Studies on Keirinbō Nichiryū (慶林房日隆): The Difference between the "Two} Half and One Whole Chapters" and The "Basic Eight Chapters" in the Lotus Sutra

This paper considers the relations between the categories which group "two half chapters and one whole" (一品二半, namely the latter half of chapter 15 , chapter 16 , and the first half of chapter 17) and the "8 Chapters" (本門八品, namely chapters 15 to 22) in the Lotus sutra commentary Hokkeshū Honmon Gugyojōo (法華宗本門弘経抄).

According to Nichiryū, the first category refers to liberation in this life (在世脱益), so 
it is insufficient, while this same category is evaluated under the second. It seems that the latter view point is his real intention.

Because Nichiryū has a strong perception of the helpless times in which we live, he emphasize reliance on Jōgyō bodhisattva (上行萻薩, viśiștacarita) for the helpless. This is because of the recognition of the centrality of the teaching of planting seeds for buddhahood (下種) given to us.

\section{Supposition on the Origins of the Nichiren Daishōnin Godenki Published in the Ninth Year of Enpō (1681)}

Horibe Shōen

Upon completing my research and analyzing the features of the Nichiren Daishōnin Godenki (日蓮大聖人御伝記), published in the Ninth year of Enpō (1681), I deliberated on the background factors involved in the writing of the text. This book had a certain status within the Nichiren Sect at the time, and deals with historical roots and references that are incomparably superior to past published biographies. Additionally, it includes various articles of information, collected without regard to loyalties to factions. It was published in Kyoto. However, I am curious as to what kind of situation allowed the assembly of such a variety of material. I could presume that at that time in Kyoto, factional borders were transcended within the Nichiren sect, and a number of individuals or groups worked together in unity. In my personal opinion, this issue must be deeply connected with the reason for the formation and publishing of the book. Thus, I bring up the subject of other biographies. However, there are still many questions remaining to be asked. For that reason, I would like to go over this matter in further detail at a later date.

\section{Late Modern Biographies of Nichiren 日蓮: The Honge Kōso Kinenroku 本化高 祖紀年録 of Fukami Yögon 深見要言}

MochIzUKI Shinchō

Although biographies of Nichiren were produced soon after his death, in modern times a great many such works have been published. In particular, looking at the style of writing, we see a shift from Chinese to Japanese, and the inclusion of illustrations as a major trend. 
This gave a big push to the propagation of the Nichirenshū and of Lotus faith. Here in this paper I wish to discuss the special characteristics of modern Nichiren biographies by focusing on the contents of the Honge Kōso Kinenroku of Fukami Yōgon. The results of my research are:

The biography is arranged in chronological order, so the reader can determine Nichiren's age at any point.

Notes are provided on Nichiren's prominent disciples and followers, with individual explanations.

Notes give reference to other biographies of and historical sources on Nichiren.

To the main contents are appended a full description of the contents and a postscript by Yōgon himself.

\section{The Idea of kenbutsu (見仏) in the Shōbogenzō (正法眼蔵)}

Dōgen (道元) dedicated a volume of his Shōbōgenzō to kenbutsu. At the beginning, Dōgen quotes words of the Buddha and explains kenbutsu, because there are the people who do not correctly understand the kenbutsu which the Buddha taught.

In the Jōtōshōgakuron (成等正覚論), a work of the Nihon Darumashū (日本達磨宗), kenbutsu also appears. However, this is the same as the kenbutsu Dōgen criticizes as mistaken. Many of the followers of the Darumashū became disciples of Dōgen. Dōgen found the teaching of the Jōtōshoggakuron to be mistaken, and harshly criticized its presentation of kenbutsu, in order to connect the followers of the Darumashū.

\section{A Study on Itsudō Kanchū}

Sugawara Kenshū

Itsudō Kanchū (乙堂喚丑) was a priest of the Sōtō sect. He was active in the mid-Edo period, and although his date of birth is unknown, he died in 1760 . He was head priest of Seitokuji (盛徳寺) in Edo and Hōsenji (鳳仙寺) in Kiryu.

He authored the Shōbōgenzō Zokugenkōgi (正法眼蔵続弦講義), Baku Bendōsho（駁 弁道書) and Tōjō Sōrinkōron (洞上叢林公論). 
The Zokugenkōgi criticizes the work of Tenkei Denson (天桂伝尊), the Baku Bendōsho criticizes Dazai Shundai (太宰春台), and the Kōron criticizes Bankai Issen (万回一線).

The Zokugenkoggi was not published in the Edo period. However, heretofore, it has been treated as a pioneer in the debate over transmission of the Dharma in the Edo period, This assessment is excessive.

Since the Genroku period, Japanese Buddhism saw intensified criticism of the Original Enlightenment idea. Itsudō also echoed that criticism.

\section{Medieval Shintō Theories in Zen kirigami: On the Sanshu no jingi and Ise niji}

Hirose Ryōbun

Dōgen transmitted Sōtō Zen from China to Japan in the early Medieval Period. In the latter half of the Middle Ages, the Sōtō school spread all over Japan. In the latter half of the Middle Ages and in the Pre-Modern age, Sōtō monks wrote many kirigami 切紙 and monsan 門参, two text genres that record secret theories and correct answers for kōan 公 案. In these texts they also adapted Shintō theories (shintōsetsu 神道説). For example, the Ippon Ken Kirigami 一本剣切紙 explains the three sacred treasures of Japan (sanshu no jingi 三種の神器). And the Ise Niji Kirigami 伊勢二字切紙 describes the hidden interpretation about the two characters $I$ 伊 and $S e$ 勢 of the Ise Shrine. It explains that $I$ stands for men and $S e$ for women. Texts about Shintō written in the Medieval Period also mention this theory. On the example of the Ippon Ken Kirigami and Ise Niji Kirigami I argue that Zen monks adapted Shintō theories in the Medieval Period.

\section{A Study of Rankei Dōryū's Rakan kōshiki: Invention and Transmission of a Bud- dhist Ritual}

Michaela Mross

The Chinese Zen monk Rankei Dōryü 蘭渓道隆（Chin. Lanxi Daolong, 1213-1278） is accredited with the composition the five kōshiki 講式 Kannon kōshiki 観音講式, Rakan $k \bar{o} s h i k i$ 羅漢講式, Nehan kōshiki 涅槃講式, Shari kōshiki 舎利講式, and Daruma daishi $k \overline{o s h i k i}$ 達磨大師講式. Paratexts included in two Edo period manuscripts of Rankei's Five Kōshiki (Daigaku zenji kenchō go kōshiki 大覚禪師建長五講式 and Daigaku zenji fuku- 
san go kōshiki 大覚禅師福山五講式) suggest two contradictory theories concerning their composition. One paratext states that Rankei composed kōshiki just after arriving in Japan for his first disciple Jakutotsu Kōben 若訥宏弁 (1217-1294). A different paratext included in the same manuscripts proposes that Rankei composed kōshiki in the last years of his life. I argue that the latter theory is more plausible.

Further, this article studies the transmission of Rankei's Rakan kōshiki in the Edo period. The paratexts of various ritual handbooks explain how the Rakan kōshiki has been transmitted from Entsūji to Kenchōji as well as from Engakuji to Tenryūji and Shōkokuji. Analyzing the content of these ritual handbooks I suggest that there were two different lineages of transmission: one centering at Entsūji and Kenchōji; and the other one at Engakuji, Tenryūji, and Shōkokuji.

\section{On Myōe's Acceptance of Yōkan's Pure Land Buddhism}

MaEgawa Ken'ichi

In one fragment of his Dream Diary that has the date " $22^{\text {nd }}$ day of fourth month" (some year before 1210), Myōe (明恵) wrote a prayer to Buddha Amitāyus, "Namu saihō Gokuraku keshu daiji daihi Amida-nyorai（南無西方極楽化主大慈大悲阿弥陀如来. I devote myself to Tathāgata Amitāyus, mentor in Sukhāvatī the westward, who has great mercy and great compassion)." The same phrase is never found elsewhere except in the $\bar{O} j \bar{o}-k \bar{o}$ shiki （往生講式; Program and Phrases of the ceremony for rebirth in Sukhāvatī) of Yōkan (永 観). This fact gives us a new key to understand Myōe's knowledge of Pure Land Buddhism. From this point of view, we can find some traces of Yōkan's Pure Land Buddhism in Myōe's criticism of Hōnen (法然).

\section{The Motive for the Production of the Ǔisang Volumes of the Kegonsh $\bar{u}$ Soshi Eden}

Atago Kuniyasu

Disagreeing with the notion that the intention behind the production of the Uisang (義 湘）volumes of the Kegonshu Soshi Eden（華㛜宗祖師絵伝）was to educate ordinary persons in the theory of Women's Attainment of Buddhahood (女人成仏), this paper argues that the true motive was to enlighten ordinary persons in the mechanism of Attaining 
Buddhahood Through One's Very Self (現身成仏).

124. The Medieval Kegon School Described in the Commentaries on the Huayan wujiaozhang 華厳五教章 Owned by the Chishakuin-shinbunko 智積院新文庫

Noro Sei

The Chishakuin Temple 智積院 possesses manuscripts of the Gokyōsho-shiki 五教章私 記, the Gokyōshō-kikigaki 五教章聴書 and the Gokyōshō-kikigaki 五教章聞書. These three commentaries are postulated to have been composed in the Muromachi period, and passed down in the Shingonshū-chizan lineage 真言宗智山派.

These comentaries are essential for examining the history and evolution of the Japanese Kegon School, since it is possible that scholar monks of the Shingi-shingon School may have participated in their composition.

This paper explores the content and doctrinal significance of these works. At the same time, it explicates an aspect of the medieval Kegon School that has not yet been sufficiently examined.

\section{An Analysis of the Study of the Buddhist Precepts in the $15^{\text {th }}$ and $16^{\text {th }}$ Centuries Based on the Scriptures Housed in the Chishakuin New Library}

ŌTANI Yuka

The study of the Buddhist precepts in Japan is generally considered to have reached its peak during the precept-revival movement of the Kamakura Period. Since then, it is said to have declined gradually, with the result that no significant developments can be dated to the beginning of the $16^{\text {th }}$ century.

An investigation of the scriptures in the possession of the Chishakuin New Library 智積 院新文庫, however, reveals that the study of the precepts continued in the 15th and 16th centuries at the temples associated with the Ebaraji Temple 家原寺, the Kaijusenji Temple 海住山寺, and the temples related to Sennyüji Temple 泉涌寺.

The movement towards the revival of the precepts that arose in the Early Modern Age did not occur accidentally or randomly, but was instead a result of a tradition of precept studies that may be traced back to the Middle Ages. 


\section{A Study on Myōhōrengegyōronshich $\bar{u}$ by Engu Housed in the Kanazawabunko}

KIM Cheon-hak

This paper aims at introducing Myōhōrengegyōronshichū (妙法蓮華経論子注, hereafter Shich $\bar{u}$ ) and figuring out the native place of Engu (円弘), the Shich $\bar{u}$ 's author who is highly likely to have been born in Silla (新羅).

There is nothing known about Engu. Annen (安然) regarded him as a scholar of the Vijñaptimātra school whose thought was different from $\mathrm{Ji}_{\mathbf{1}}$ (基). On the other hand, Gomyō (護命) was said to have recited Engu's works with Woncheuk (圓測)'s. Among Engu's works, Engushishō (円弘師章) and Shich $\bar{u}$ had been transcribed since the Nara（奈良） period. As investigating the citations of Engushishō, we became to know that Engu's thought was different from $J_{1} 1$ and Engu accepted the theory of the old Vijñaptimâtra school, which were the common tendency of the scholars of the Vijñaptimattra school in Silla.

Shich $\bar{u}$ is housed in the Kanazawabunko (金沢文庫) and only the last roll of Shich $\bar{u}$ is extant but its last part is missing, besides, the remaining part has also many lost phrases within it. As the content of Hokekyōronch̄ (法華経論註) written by Jōtō (常騰) and cited by Tan'ei (湛故) is almost identical with Shich $\bar{u}$, it is certain that Shich $\bar{u}$ is cited in Tan'ei's works. However Tan'ei did not cite it directly. The first instance of directly citing Shich $\bar{u}$ is Juryō (寿霊)'s Gokyōshōshiji (五教章指事).

The thought of Shich $\bar{u}$ is influenced from Jízàng and Jī but different from Xuánzàng (玄 奘)'s line considering that Shichu admitted the possibility of enlightenment of śrāvakas whose nature is fixed. These works of Engu had received wide attention from monks of the Hossō (法相) school, the Kegon (華稂) school and Tendai (天台) school in Japan.

\section{Reconsideration of the Debates Conducted at the Hosshōji Mihakkō}

Minowa Kenryō

In terms of the content of debates, my examination of the Hosshōji Mihakkō Mondōki (法勝寺御八講問答記) suggests that there were two types. The first is a debate that aimed at explaining and integrating seemingly contradictory interpretations of Buddhist scriptures (ets $\bar{u}$ 会通). The second type of debates intended to prove that two contradictory positions 
were both true ( $r y \bar{o} y \bar{o}$ 雨様). The second type of debates was used primarily by the Questioner; when the Questioner was able to raise a question that would eventually lead to ryōyo, he would win the debate. On some occasions, the Lecturer, too, used ryōyo in answering a question raised by the Questioner. There were three types of phrases used to describe $r y \bar{o} y \bar{o}$ : "I may answer in two ways," "It is not clear both ways," and "I may criticize in two ways."

These two types of debates continued to be conducted in subsequent periods. In the Nanbokuchō era, debates were classified into three types: $r y \bar{o} y \bar{o}, t s \bar{u} k u$ 通局 (integrating contradictions), and jōhan 定判 (fixed judgment). The first two of these three types originally developed from the two types of debates conducted at the Hosshōji Mihakkō.

\section{Aspects of the Early Edo Period as Seen in Chōzen's Shikoku henro nikki}

ShIBATANI Sōshuku

Through a close reading of the Shikoku henro nikki（四国辺路日記, 1653) of Chōzen (澄禅, 1613-1680), details of the Shikoku pilgrimage in the early Edo period were learned. The information in this diary also extends to the situation in contemporary towns and details of lifestyle. There are numerous accounts concerning castle towns, the actions of administrators, and reflections of ordinary social conditions. Many tales circulating at the time are also included.

The circumstances in castle towns throughout Shikoku are given in careful detail, including the facts that Kōchi was administered by Nonaka Kenzan (野中兼山, 1615-1663) and Confucian funerary rituals were carried out.

The customs of the commoners of each province are summarized. The people of Awa and Tosa are described as simple and compassionate, while the people of Iyo and Sanuki are shown as urbane and religious.

The story of Emon Saburō (衛門三郎) given in Chōzen's diary is nearly the same as that told about the originator of the Shikoku pilgrimage today, with a few differences. Today it is said that Emon Saburō was the headman of the village of Ebara where Kōbō Daishi came seeking alms, and the site is now that of Monju-in temple (outside of the eightyeight temples). However, in Chōzen's diary they first met in the precincts of the Yasaka-ji temple, where Saburō was cleaning. Today it is said that he traveled the pilgrimage route in 
reverse twenty-one times, but that story is missing in the diary.

\section{Religious Control in the Okayama Feudal Domain (Okayama Han 岡川藩)}

SAKawa Senshō

This paper studies the policy toward religion of the Okayama feudal domain, through the window of temples and priest, in particular of the Nichirenshū. The domain controlled the monks through the family register, with strict control kept of residence and travel. Rewards and punishments were also employed, and the right to permit religious activities was also retained by the domain.

\section{Kanchū's Ganshō-Kimyō（願生㷌命）Doctrine: A Decipherment of the Kondō- Zaijya-Hen (建幢摧邪篇)}

\section{NiSHIHARA Norioki}

When discussing the Sangō-Wakuran (三業惑乱) incident, we have to note that the key argument is older. It is important to pay attention to the dispute of Hoggon that argues against the Ganshō-kimȳ̄-ben (願生帰命弁) written by Kōzon and Kanchū defence of Kōzon. The criticism of the Kimyō-hongan-ketsu (㷌命本願訣) in the Kondō-zaijya-hen amounted to 305 items, and their structure is complicated. We can learn Kanchu's idea by reading the Kondo-zaijya-hen (1789) that he wrote in the prime of his life. Summarizing that book, we can decipher four focus points of Ganshō-kimyō doctrine.

1) "Tanomu" means kimyō (to take refuge in Amida-Buddha) and aspiration for birth in the Pure Land. 2) Aspiration for birth (yokushō) is a shape of entrusting (shingyō). 3) It is the ten kalpas Anshin (十却安心) that determine that only entrusting in the threefold mind is a true cause resulting in birth. 4) Expressing the three modes of action is the way to promote Shinjin.

On the other hand, in the Shinshu-anjin-shōchüroku（真宗安心正中録）(1804） that he wrote in his later years, he adapted sentences to the current environment. Therefore, the tone is a little more gentle than the Kondō-zaijya-hen. In addition, he states that there is a right form of Shinjin in 'Shōchu' that is an impartial thought between entrusting and aspiration for birth. Probably he tried to integrate the Ganshō-kimyō and Shingyō-kimyō doc- 
trines. However, that integration does not provide a proof of his conversion.

\section{Deployment of “Non-duality 不二” by Muneyoshi Yanagi: With Reference to His Work Namu-amida-butsu 南無阿弥陀仏}

Hasegawa Tsugumi

Muneyoshi Yanagi was a philosopher of religion, and the founder of "Mingei 民芸（The folk craft)" movement. He conceived of Mingei aesthetics, as he based on absolute monism, and this absolute monism is also the foundation of his thought. The Buddhist term "nonduality" concretely describes his thought. In particular, he investigated the "non-duality" of Zen and Pure Land Buddhism. It is in his work Namu-amida-butsu that the influence of this "Non-duality" thought is seen. This thesis considers his ideological point of view from the non-duality expressed in his Namu-amida-butsu.

\section{Representation in Gold and Silver Ink of Mandalas and Buddhist Scripture}

Manabe Shunshō

In Buddhism one-dimensional mandalas and scripture and three-dimensional statues are often objects of veneration.

In terms of the representation of color, the use of gold and silver ink has been a major technique employed in painting and in writing-particularly in the painting of Buddhist images and the copying of scripture. This is especially the case when emphasizing the representation by using gold or silver ink to highlight the outline of Buddhist images and of calligraphy of scripture. In the case of the National Treasure Takao mandara with its deeppurple twill ground and of the National Treasure Chüsonji kingin kōshakyō with its darkblue ground, Buddhist deities and text have been carefully rendered in gold or silver ink on the dark background.

In the creation of the $12^{\text {th }}$-century Shaka nyorai image at Jingoji in Kyoto, popularly known as the "Aka Shaka" (Red Śākyamuni), the Buddha is depicted clad completely in a red robe over which intricately fashioned cut-gold leaf (kirikane) has been applied. Both the body and the robe of Śākyamuni are rendered in gold in order that he may exercise his merit, but why was the color red emphasized in addition to the gold? This new conception, 
i.e. the idea of combining these colors, led me to consider this as a basis for the later technique of the alternative use of gold and silver ink. This also seems to be a reason behind the production of the Heike nōkyō (from 1164), an exquisite ornamental sūtra enshrined in Itsukushima Shrine in Hiroshima. In this article, I seek the reasons for the creation of these objects in the $12^{\text {th }}$ century, which was considered the final age of the dharma (mappō). In other words, the question here is how these methods of representation are related to merit (Skt. guna) of the Buddhist deities and words, i.e. the problem of their mutual relationship in terms of faith. Then, the problem of the five human senses and their relation to faith in terms of the effect of the colors gold and silver, which has seldom been addressed, also arises. This is made possible by Esoteric Buddhist faith in this-worldly benefits that stresses the senses, and here I consider the basis for the origin of such issues. Ultimately, it is the effect (Jpn. gaho $)$ of merit that is responsible for the creation of the method of alternating gold and silver used in calligraphy for sutras. I also explore the powerful impact that accompanies the consciousness of the design. Furthermore, by comparing the method of depiction in gold and silver ink employed in the Takao mandara, the oldest extant "Genzu mandara" in Japan, and the method of calligraphy used in the twenty scrolls of the Kiyohira sutras and the 600 scrolls of the Motohira sutras at Chüsonji, I have been able to clarify the position of the true value and essence of their shared effect. This also leads a consideration of nature of this merit, in short, the Esoteric Buddhist art aesthetic of the "eternal" and the "instantaneous." Finally, while reviewing the method of representation with gold and silver ink that was established in the Heian period and developed as a unique method of representation in Japan, I also explore the special characteristics of this method.

\section{The Revitalization of Korean Buddhism and Its Possibility for Success in Con- temporary Society}

FuJI Yoshinari

After institutional democratization in 1998, the Chogye order began to develop proactive programs propagating their teaching to lay followers. In 2005, they established the following five-point action plan: (1) strengthening temples in urban areas; (2) training priests specializing in propagation in urban areas; (3) energizing lay followers' organizations in areas without base temples and where there are difficulties for priests to propagate the 
faith; (4) development of practice and propagation programs aimed at people living in urban areas; (5) promoting the propagation of teaching involving social welfare programs and appealing to cultural heritage.

When I visited Korea in 2010, I witnessed this plan already achieving good results in the promotion of the Chogye teaching in urban areas, linking propagation programs with social welfare and cultural heritage, as well as the development of educational program for lay followers. I found that Buddhist communities had many young members with increasing numbers of male followers, well-developed lay Buddhist organizations, and lively religious activities in the temples. I also noticed that those who participated in temple activities had great pride in their faith, were strongly motivated to learn and practice Buddhist teachings, and had high consciousness in volunteer services.

\section{An Interpretation of "Movement and Stillness" in the Wubuquian-lun of the} Chaolun

Suemura Masayo

This paper was written to interpret the thought of the movement and stillness of things as presented in the Wubuquian-lun 物不遷論 of the Chaolun 肇論. The Chaolun is a collection of theses written by Sengzhao (374/384-414) 僧肇, Kumārajiva's 鳩摩羅什 disciple, and the Wubuquian-lun is its first thesis. In this thesis, Sengzhao preaches principally about the movement and stillness of things. In terms of his thought, movement and stillness do not differ, the two are one and the same thing. However, it is well-known that the fundamental idea of Buddhism is that everything is impermanent. Since this doctrine would consider all things as movement, it would seem that preaching about stillness of things is contrary to it. It is, however, unlikely that Sengzhao, who was well versed in the theory of emptiness, simply discounted it. So this paper suggests that movement should be understood as the temporal way of existing, and that stillness should be understood as the spatial way of existing. By interpreting Sengzhao's thought in this way, movement and stillness can be made to coexist without contradiction despite being antonyms. 


\section{The Teaching in the Missing Portions of the Tiwei boli jing}

YAMAGUCHI Daisuke Ishin

The Tiwei boli jing 提謂波利経 had been thought lost until Zenryū Tsukamoto 塚本善 隆 (1899-1980) identified 21 fragments of the text from various Buddhist works. These fragments are collectively called the 'Tsukamoto Fragments.' Later, Tairyō Makita 牧田諦 亮 (1912-2011) used four Dunhuang 敦煌 manuscripts to reconstruct most portions of the two-volume Tiwei boli jing. In doing so, he proved that most of the Tsukamoto Fragments did indeed come from that text, but Tsukamoto Fragment No. 15 and others that could not be identified in Dunhuang manuscripts remained to be identified. I discovered three new fragments of the Tiwei boli jing by using the digital database of the Chinese Tripitaka. Recently, I came to the conclusion that these three fragments, together with Tsukamoto Fragment No. 15, originally belonged to the same portion of the text, so that they proved to form one and the same group. This discovery demonstrates that the doctrine at the beginning of the two-volume Tiwei boli jing which is expressed in about 1300 Chinese characters seems to be associated with these four portions. This can help us to understand the content of a heretofore unknown portion of the Tiwei boli jing.

\section{The Relationships Between the Theory of Two Kinds of Dharma-Body and the Extensive and Brief Interpenetrate in the Wangsheng lunzhu}

I survey the relationships between the theory of two kinds of dharma-body and the extensive and brief interpenetrate, based on the inclusiveness and correspondence of terms and meanings in the Wangsheng lunzhu. As a result of this survey, I have come to conclude that although "the extensive the dharma-body as suchness" has commonly been accepted, interpenetrate is not equal to dharma-body as suchness but equal to dharma-body.

\section{Influences of Buddhism in Southern Dynasty China upon Tanluan 最㝈}

UCHIDA Junshin

Studies on the background of Tanluan's thought have concentrated on the Buddhism of 
the Northern Dynasties, and hardly problematized the place or time in which he studied the Madhyamaka thought of Sengzhao 僧肇. I look at this question in light of Northern and Southern Dynasties Buddhism. I conclude that Tabluan may have been influenced by the emptiness idea of Sengzhao's works and the Southern Sanlun school. At the same time, Tanluan and Jizang 吉蔵 share many expressions, showing their mutual philosophical background. Examining both scholars and their commonalities will permit a clearer view of Tanluan's thought.

138. On the Interpretation of '如観経具説' in the Wangsheng lichan ji Compiled by Shandao

Uesugi Tomofusa

As underlined, the passage “如観経具説” in the Wangsheng lichan ji 往生礼讃偈 (T47., No. 1980) compiled by Shandao 善導 (613-681) indicates the Guan wuliangshou jing 観 無量寿経 (abbr. 観経) as canonical authority. In the Guan wuliangshou jing, however, we can not find a sentence of such authority. For this reason, to settle this question some interpretations have been offered. In this paper, by examining the usage of 具 found in the Shandao's works, I also suggest an interpretation of ‘如観経具説' different from those in previous studies.

139. The Doctrine of the "Dual-Nature of Reward Realm and Transformation Realm" in Jiacai's Jingtu lun: The Relationship between "Birth in the Pure Land" and "Seeing the Pure Land"

KuDō Ryōdō

Jiacai 迦才 was an Amitābha believer living in Chang'an during the early Tang era. His doctrine of the "Dual-Nature of Reward Realm and Transformation Realm" has been considered one of his characteristic theories on Pure Land Buddhism. However, it has been negatively evaluated as merely a position of compromise. Yet this doctrine is not original to Jiacai. Based on a background study of the Dasheng qixin lun 大乗起信論 and Paramārtha's translation of the Mahāyanasamgraha-bhāsya, we can say that this doctrine was common among various Buddhist masters at that time. The special features of Jiacai's doc- 
trine are two-fold. First is his emphasis on the triple nature of the Western Pure Land as simultaneously the dharma realm, reward realm, and transformation realm. Second is his discourse on the relationship between "Birth in the Pure Land" and "Seeing the Pure Land." According to Jiacai's doctrine, after achieving birth in the Pure Land, the Pure Land would appear differently to believers depending on their level of practice. Furthermore, this can be understood as Jiacai's response to the issue of the "Prediction and Fulfillment TimeGap" (bieshiyi 別時意). In conclusion, Jaicai's doctrine, which had been considered to have been based on a position of comprise, when analyzed in the context of the philosophy of the time, comes to be seen as actually an original and ingenious solution.

\section{On Practices Discussed in the Biographies of Birth $(\bar{O} j \bar{j} d e n)$ : Particularly Focus- ing on the Understanding of Nembutsu Thought}

YAMASAKI Shinjun

In his Commentary of the Contemplation Sutra, Chinese Master Shandao identified the recitation of the nianfo as the "act of the truly settled." In the Guannian famen and the Wangsheng lizan, he rephrased the word nian 念 in the Eighteenth Vow of the Wuliangshou jing as "recitation" (cheng 稱) in order to clarify his interpretation of nianfo recitation as the right act for birth in the Pure Land. Regarding Shandao's influence upon subsequent followers, Shibata Tōru has published his study on this topic by examining Shandao's position in the various lineages of the Pure Land teaching found in different texts.

In my study, however, I would like to study Shandao's influence by reexamining the transmission of his understanding of the Pure Land practice particularly focusing on the nembutsu thought discussed in the Biographies of Birth. In this paper, I examine the Pure Land practices found in the Wangsheng Xifang jingtu ruiyingshanzhuan, especially the type of nianfo practice performed by those who attained birth in the Pure Land.

I will also consider the relationship of Jiacai's Jingtu lun (mid-7th century) and Jiezhu's Jingtu wangsheng zhuan (comp. later than 984-987) in regard to Shandao's influence on the development of nianfo thought discussed in the Biographies of Birth. 


\section{On the Metaphors of the älayavijñäna in the Cheng weishi lun}

YoshimuRA Makoto

The metaphor of turbulently-flowing water, used extensively in the Āgamas and Abhidharma texts as a metaphor for affliction (kleśa), is applied in the Trimśika 唯識三十頌, as a metaphor for the alayavijñäna. This metaphor shows that the alayavijñana remains constant while at the same time transforming itself in accordance with the principle of cause and effect. The Cheng weishi lun 成唯識論 depicts this metaphor in three ways:

1. In the same way that a turbulently flowing river submerges and raises the objects it carries along, the àlayavijūāna raises sentient beings to fortunate states of existence and submerges them in evil rebirths.

2. In the same way that a turbulently flowing river creates waves in conjunction with the wind, the alayavijūana, in conjunction with various causes and conditions, produces and extinguishes various transforming conciousnesses.

3. In the same way that a turbulently flowing river carries along fish, weeds, and so forth, the älayavijñāna incessantly transmits the omnipresent mental factors and seeds (bijja).

Although all these explanations have come from Vasubandhu's commentaries on the Mahāyāna-samgraha 攝大乘論釋, it is clear that only the second simile is original. Its depiction is the same as that of the simile of water and waves found in the Awakening of Faith 大乘起信論. The sources of those descriptions can also be seen in such texts as the Avatamsaka-sūtra 華嚴經 and the Samyuttanikāya.

These examples show that the traditions known as vijñapti-mātratā and tathāgatagarbha have shared not only the motif found in early Buddhism but also have transformed such descriptions to accord with their respective doctrines. The same example can be seen in the description of the simile of gold ore.

\section{The Three Categories 三聚法: The Category and System of dharma before Xuán- zàng 立奘}

Окамото Ippei

The purpose of this paper is to consider the category and system of dharma before Xuánzàng (玄牀 602-664). In China, the five categories (五位), that is, the classification 
method of the dharma, became well known after the translations of Xuánzàng. But the classification method of dharma before Xuánzàng remains unclear. I would like to consider this problem focusing on the three categories (三聚法, sānjùfă) of Jìngyìngsì Huiyăn（净 影寺慧遠 523-592).

The three categories are rūpa (色), citta (心), and viprayukuta-samskāra（非色非心, 不相灾行)。

Huiyăn explained these in most detail in his Dāshèn yìzhān 大乗義章 sanyouwéiyì 三有 為義 (T.44,pp.491b-496c). Although the three categories are similar to the five categories, the two mainly differ in two points. In the first place, Huiyăn classified not only samskrta but also asamskrta by the three categories in his Wéimó yiji 維摩義記 (T.38,p.494c). In the second place, he didn't use caitta (心所) as an independent category.

Huiyăn systematized the dharma of the Sarvāsti-vāda (75 kinds), * Satyasiddhi-Śāstra 成実論 (53 kinds), and Mahāyāna (undecided) by the three categories. Following the Silún xuányi 四論玄義, I conclude that Chéngshíshī's 成実師 theory was the model of Huiyăn's the categories.

The three categories were quoted by contemporaries of Huiyăn. But the description of the three categories fell out of favor since Xuánzàng's translation used came to be, because the five categories were considered an authoritative theory.

\section{A Study of Tiantai Zhiyi's Notion of Śākyamuni Buddha: With Emphasis on the Analogy of Śākyamuni to a King}

TAMURA Kanji

In Mahāyäna and Hīnayāna sutras and treatises, many references and allusions are made of Śākyamuni Buddha to a King. Tiantai Zhiyi (538-597) accepted these sutras and treatises and developed his own unique notion of Śakyamuni as the "King of the Teaching." This paper seeks to examine texts such as the Weimajing xuanshu 維摩経立疏, Weimajing wen$s h u$ 維摩経文疏, Fahua xuanyi 法華玄義, Fahua wengou 法華文句, and Mahezhiguan 摩 訶止観 in verifying that the aforementioned analogy has its basis in the concept of wangsanmei (王三昧 or samādhi of the king). According to Zhiyi, wangsanmei encompasses all forms of samādhi such as: the samādhi of the dharma-kāya (fashen 法身) characterized by yuanjiao (円教), the greatest of the four types of teaching (sijiao 四教); the samādhi that 
totally realizes all the buddhas of the ten directions; the samādhi of kongjiazhong yuanrong sandi (空仮中円融三諦) or that of the complete integration of a world with no form, a world dependent upon expedient forms, and the world of truth; the samādhi of ultimate $s \bar{u}$ nyatā; the samādhi of the middle way and of truth; the samādhi of śamatha-vipaśyanāa (止 観); the samādhi that incorporates both truth and wisdom; the samādhi that ends attachments and ignorance; the samädhi that teaches by appearing in different forms throughout the ten worlds (十法界); and the samādhi that relieves the confusion of ershiwuyou (二十五有)， referring to the 25 varieties of sentient beings in bewilderment. In conclusion, wangsanmei covers all of the important central themes of Zhiyi's scholarship. Zhiyi compares Śākyamuni Buddha's true form that is the dharma-kāya to an imperial leader who asks the help of a fawangzi (法王子, a bodhisattva who has attained partial enlightenment) to lead the Buddha-world and all sentient beings (the prince, being a child of the king as well as a subject of the king, is motivated by filial piety and loyalty to save the king), and rule the Buddha-world and lead all sentient beings, maintaining the zhongxing (種性, lineage originating from the core seeds sewn by the Buddha) of the Buddha-king. Furthermore, the teaching of the Buddha is analogous to a king's royal edict. Zhiyi explains that kaihui (開 会) or absolute affirmation, that of discovering the worth of intermediate teachings and individuals under the auspices of complete teachings (yuanjiao), such as that of the Lotus Sutra, is a merit of the king of the dharma.

In addition, this paper indicates which sutras and treatises were most influential in the development of Zhiyi's concept of wangsanmei. Examples of influential sutras include: Dapin banre jing 大品般若経, Renwang banre jing 仁王般若経, and Nieban jing 涅槃経。 The most influential treatise is the Da zhidu lun 大智度論.

The author would like the reader to understand that this paper is still a tentative work in progress and does not attempt to comprehensively review all of Zhiyi's writing. The author is considering a continuation of this research in the future.

\section{Zhìxù's Interpretation of the Śūramgamasamādhisūtra's Nianfo sanmei}

SHINODA Masayoshi

This paper examines Zhìxù's (智旭) interpretation of the phrase nianfo sanmei (念仏三 昧) in the Sūramigamasamādhisūtra (首椤厳経). One sentence of the sūtra says "by con- 
templating all things that have the six sense organs (六根), and all things connected with enlightment, you shall obtain samādhi (三摩地).”Zixuan (子瑢) interpreted the sentence saying that smrti (念) belongs to manas (意根). The six sense organs belong to manas. Manas is suunya. If you understand the six sense organs, you can obtain enlightment.

Zhìxù's interpreted the sentence saying: “Don’t produce kleśa (煩㥗) through the six organs," connecting this with his understanding of the three-kāyas (三身) and four kșetras (四土).

Zhìxù's interpreted nianfo sanmei in three ways, of which thinking of Buddha in your mind he estimated to be the highest.

\section{Huangbo Xiyun and the Great Anti-Buddhist Persecution of Huichang: From the Ideas of Chuanxin Fayao}

Ogawa Tairyū

The aim of this article is to clarify the ways in which Chan sects survived the Great AntiBuddhist Persecution of Huichang 会昌. The Buddhist sects of the Tang Dynasty experienced the devastation caused by the Persecution. However, the Chan sects reinforced their influence at a turning point in the Persecution. I examine the reason why the Chan sects were able to expand at that time by using the text of the Chuanxin Fayao (Essential of Mind Transmission, 伝心法要), which consists of quotations on Chan from Huangbo Xiyun 黄 檗希運（d. 850） and is one of the representative sources for the period of the Tang Dynasty. In this article, I research the thought of Huangbo Xiyun, on the Three Treasures of Buddhism 三宝 destroyed by the Persecution. In conclusion, the survey found that the thought of "non attachment" (無執着) afforded the key to the survival of Chan sects through the Persecution. I also found that "compassion" (慈悲心) and "the acceptance of intellectual comprehension" became the driving forces behind Chan sects after this Persecution; thus they could recover.

\section{Vairocana and Śākyamuni in the Avatamsaka-sūtra}

This paper focuses on the relationship between Vairocana and Sākyamuni in the Avatam- 
saka-sūtra as seen through the dharmakāya and rūpakāya. Vairocana is known as the main buddha of the Avatamsaka-sütra, while Săkyamuni, who is looked upon as the same deity as Vairocana, also appears in the sūtra.

Unlike the later interpretation where the theory of the three bodies (dharmakāya, sambhogakāya, nirmanakāya) of Buddha is used to assimilate the two Buddhas, the theory of the two Buddha bodies, dharmakāya and rüpakāya, is used to explain the relationship between Vairocana and Śăkyamuni in the Avatamsaka-sütra. Vairocana is regarded as dharmakāya and Śăkyamuni as rūpakāya. This contradicts the traditional explanation in which dharmakāya is the very truth which cannot be touched or seen. Vairocana, who is the Buddha of dharmakāya, has a visible body in the Avatamsaka-sütra. This is also said to be characteristic of the Avatamsaka-sütra.

Furthermore, though Vairocan and Śākyamuni are the same deity, they have different bodies. According to the Avatamsaka-sūtra, Vairocana and Sākyamuni look different because of the degree of the practice of those who see the Buddha.

\section{Psychiatric Problems Related to Alcoholic in Ancient India}

MoRiguCHI-SHINODA Mai

The purpose of this paper is to examine psychiatric problems involving alcohol, focusing on the Carakasamhitā (CS) and Suśrutasamhitā (SS). Drunkenness is named mada generically and positioned as a disease. However, the definition of mada in CS was ambiguous, being related not only to alcohol but other toxic symptoms may also have been included, and it is explained as related a morbid mental condition caused by personality. On the other hand, SS clarified the definition of mada left unclear in CS, and regarded it as acute alcoholic poisoning.

CS has a description similar to the symptoms of alcohol withdrawal applied to alcohol dependence. Moreover, CS and SS have lists of critical illnesses caused by morbid drinking of alcohol.

Therefore, it may be grasped clinically that dependence arises precisely from continuous drinking of alcohol. However, the term "dependence" is not used. Moreover, from descriptions in the law books, there is also the possibility that those with acute-alcohol-poisoning and alcohol dependent persons had received another treatment. 


\section{Samyama in the Old Jain Āgamas: Its Meanings and Textual Traditions}

WATANABE Kenji

Samyama is a very important attitude in Jaina religion: the monk should have equanimity and should avoid all sinful acts. The important point to note here is that samyama has essentially to do with physical conduct (cāritra) and physical restraint. The term samyama was first used in the history of Mahāvīra with reference to a restraint (sāmāiya-samjama) undertaken by Mahāvīra when he renouced the world; there it involved nothing less than the abandonment of all sinful acts. In the old Āgamas the various derivatives of sam $\sqrt{ }$ yamare found with either the locative or the instrumental or dative case in the senior Jain canons. It is interesting that exactly the same distribution of case forms is found in Aśoka's Rock Edict VI, where the Eastern dialects have mahāmātehi "to the ministers" in Dauli. This form is replaced by mahāmātresu at Girnar in the West.

\section{Kumārila on Tolerance}

YosHimizU Kiyotaka

The second section of the Mimāms āsütra (MmS) 2.4 attempts to prove the unity of the Vedic $s \bar{a} k h a \bar{a}$, despite a lack of uniformity regarding about how to perform a sacrifice. In his commentary on this section, Kumārila makes an excursion in which he esteems one's affiliation to a particular śăkhā. Because there is a mutual expectation $(\bar{a} k \bar{a} \dot{n} k s \bar{a})$ among different Vedas at the performance of a sacrifice, it is desirable for one who has learned one of the three Vedas to learn the other Vedas together (samuccaya). But because there is no mutual expectation among the texts of the same Veda transmitted by different $s \bar{a} k h \bar{a}$ s, there is no practical need to learn other śăkhās, and one should choose (vikalpa) one śăkhă. Moreover, in rejecting an advocate of Vedic globalization who insists that all people should learn a single powerful śăkhā, Kumārila admonishes not to neglect the siakkha to which one's family has hereditarily been affiliated.

Kumārila's exhortation to be strictly faithful to one's hereditary śākhä might give an impression that he promotes complete indifference to, or intolerant rivalry against, other $s \bar{a} k h \bar{a}$ s. But he undoubtedly stands by the proponent of this section, and even demonstrates the possibility to thoroughly study the texts of other $\dot{s} \bar{a} k h a \bar{s}$ by paying attention to a sacri- 
fice's structure common to different śâkhhās.

How then can the fidelity to one's śâkha be consistent with the inquiry into other śăkhās? A key is found in a section of the Tantravārttika on the authority of smrti texts (MmS 1.3). Under the assumption that each provision of a smrti text has been laid down in the Veda and transmitted until now, but scattered (viprakirnna) in various śākhās, Kumārila expounds a tolerant view that one should not despise the behavior of others insofar as there is the possibility that it is based on the Veda of their own śākhās. But we should not overlook the fact that he severely criticizes non-Vedic religions. Kumārila's spirit of tolerance is inseparable from his convinced intolerance against the religions that do not share the Vedic dharma.

\section{The Definition of 'Word' in the Tattvabindu}

KAWAJIRI Michiya

In his Tattvabindu, Vācaspatimiśra criticizes sphoṭa theory on the grounds that the essense of language is the phoneme (varna). Vācaspati insists that phonemes are recalled by means of residual impressions (bhāvanā) after each percipience, and that such recall contributes to the understanding of the meaning of a word as a unit. He rejects the supposition that the single body of the word conveys its meaning because understanding of the meaning of a word and word-recognition depend on each other (anyonyāśraya).

The author concludes that Vācaspati's idea as mentioned above corresponds to his supposition of some unit between phonemes and meaning, and that it may be a compromise to sphota theory.

\section{A Clarification of the Yuktidīpikā's Interpretation of āptaśruti in Sāmkhyakārikā} 5 and Its Implications

Kondō Hayato

In his Sāṃkyyakārikā (SK) 4, İ́varakrsṣna (ca. 4-5 $5^{\text {th }}$ c. CE) accepts āptavacana as a valid means of cognition (pramāna) in addition to perception (drșța) and inference (anumāna). āptavacana is paraphrased as aptaśruti (SK5d') or āptāgama (SK6d'), but the SK does not explain what this "āpta" means. The Yuktidipika (ca. 680-720 CE, YD), an anony- 
mous commentary on the SK, first interprets the compound "āptaśruti" in two ways: (1) karmadhāraya (āptā cāsau śrutiś cāptaśrutih) and (2) pañcamī-tatpuruṣa (āptebhyah śrutir āptaśrutih). Finally, the YD offers the (3) ekaśeșa interpretation (āptaśrutiś cāptaśrutiś cāptaśrutih) of this compound. According to this (3) ekaśesa interpretation, the first "äptaśruti" represents (a) the authoritative (āpta) scriptures that are not based on human intelligence, namely the Vedas, and the second "aptaśruti" means (b) the transmitted texts or words which are attributed to trustworthy persons (apta), such as smrtis compiled by Manu and so forth. Previous studies did not clarify the relationship among these three interpretations. The present paper gives the following answer. The YD supports the ekaśeșa interpretation instead of showing three alternatives. The (1) karmadhäraya interpretation corresponds to (3) (a). Here "appta-" does not refer to a trustworthy person, but qualifies the "-śruti," meaning "authoritative scriptures" that are the Vedas. On the other hand, the (2) pañcami-tatpurușa corresponds to (3) (b). Here "apta-" represents the "reliable persons." Thus "āptaśruti" refers to the transmitted texts attributed to reliable authors. In this way, both the (1) karmadhāraya and (2) pañcami-tatpuruṣa interpretation are unified into the (3) ekaśeșa interpretation. The reason for this apparently awkward interpretation seems to be clear. The YD aims at including the meaning of authorless Vedas into the compound "aptaśruti." But the question remains to be solved in future study whether the authorless Vedas were accepted as a pramāna in earlier times of Sāṃkhya.

\section{The Vaišeșika Theory of Categories and Abhyudaya}

SuZUki Takanori

Although the Vaiśesikasütra refers to achievement of heaven (abhyudaya) and emancipation (nihśreyasa) as religious goals to be pursed, it does not clearly mention how they relate to the system of categories, which strongly characterizes Vaiśeșika theory. Clearly presenting the knowledge of categories (tattvajñana) as the cause of emancipation in his Padārthadharmasangraha, Praśastapāda uses the word mahodaya, which seems to be relevant to abhyudya, in the mangala verse to announce what his book would offer. While Praśastapāda himself does not make clear what mahodaya signifies, Udayana interprets the word to mean tattvajñāna in his Kirañāvalī. Through this unique commentarial activity, we are able to see Udayana's intention to distance the aspect of achievement of heaven, which 
was held as a religious goal in early Vaiśeșika, from its entire history.

\section{Our Constituents (dharma), Existence (bhāva) and the Existent (sat)}

\section{MURAKAMI Shinkan}

1. The system of early Buddhism is mainly based on our being's constituents (dharmāh, dhammā) which are impermanent, painful and not the self.

2. Momentary existences are directly grasped by perception. Vasubandhu $\left(4-5^{\text {th }}\right.$ century) asserts as a new theory of momentary destruction (kșana-bhanga) that the existences $(b h \bar{a} v \bar{a} h)$ are momentary, i.e. at the moment when they arise they vanish without any cause (AKBh.p.194).

According to Dharmakirti (early $7^{\text {th }}$ century), what is existent (sat) is only momentary (kșanikam). If it is not momentary, because this is contradictory to useful activity (artha$k r i y \bar{a}$ ), it fails to be real fact (vastutvam) which has that characteristic of useful activity $\left(H B . \mathrm{I}, \mathrm{p} .37^{6-7}\right)$.

Jñānśrīmitra (ca 980-1030) says: What is existent is momentary just like a rain cloud (yat sat tat kșanikam yatha jala-dharah). Yet these existences are existent (santas tu bhä$v \bar{a}$ ime). [Therefore these existences are momentary]. Here existentness is potentiality to useful activity (sattā śaktir artha-karmani. Jñānśrimitra-nibandhāvalī p.1). While the momentary destruction is not proved, its understanding is still ascertained by perception (pratyakșena graha-sthitih). Its momentary destruction is ascertained because of being understood through perception (pratyakṣena grahād asya kṣaṇa-bhanga-vyavashtitih. Jñān-

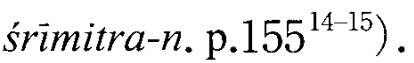

These existences are existent and stand for the conditioned elements (samskrtā dharmāh), i.e. the perceptive (rüpa), the mind (citta), and mental functions (caitta, caitasika), all of which are called simply dharmāh (constituent elements, functions, or properties of our life, i.e. our existence).

\section{Sañ̃̃ā in the Suttanipāta}

NAKATANI Hideaki

On the basis of philological investigations, three layers can be clearly distinguishable in 
the Suttanipāta. In this paper a development is clarified in the meaning of the word sañña in these layers.

According to the Atthaka-vagga, the most ancient text of the most ancient layer (first layer), sañña is the sole entity constantly existing and, when it goes from an ordinary state into an ideal one, the ambient world one perceives should disappear, i.e., the world should totally change. It would be 'cognition' that can be characterized as such.

In the Pārāyana-vagga, the second most ancient text of the first layer, the ideal state of sañña is described always with reference to the state of having nothing (ākiñcañña). The poet seems to understand that the disappearance of the perceived objects for the ideal sañña should take place because the person goes into the state of having nothing - an understanding slightly different from the original one in the Atṭhaka, though the meaning 'cognition' of sañ̃̃ā remains the same.

In the second layer, sañña seems to be described always as injurious disposition of mind', such as resentment or deep attachment, and never as being in an ideal state. This seems to take a first step to the theory of five aggregates which will be established in the third layer and will claim that suffering ceases by relinquishing aggregates including saññā.

\section{Historical Classification of Suttanipāta Texts by Metre}

The Suttanipāta is known to include the oldest discourses of Buddhism and consists of different parts which are historically distinct. Indian metres were constantly changing from the Vedic age. Therefore, it is possible to conjecture the date of composition of texts based on metrical criteria. This paper attempts to find differences between the older part (layer Ia: Ațthakavagga, layer Ib: Pārāyanavagga, Khaggavisānasutta) and the newer part (layer II: other verses except for Vatthugāthā) of the Suttanipāta. The Pāli language has rich epentheses of vowels. However, some epentheses should be eliminated from the view of metre. Examining the whole text of the Suttanipāta, we found that the older parts do not allow new epentheses, though they are written as such in the transmitted texts. Another matter is the restriction of caesura in the break of the tristubh. As Smith (1950) indicated, caesura after the 5 th syllable is needed when three short syllables appear in a break. But this tendency declined with the passage of time. We can also presume the relative period of 
texts from the breaks and the caesurae. In conclusion, there are great differences between layer I and layer II, with layer Ib showing a transitional stage.

\section{On the Zhongbenqi jing}

\section{OKUMURA Hiroki}

In this paper, I compare the biography of the Buddha found in chapters one through five of the Zhongbenqi jing 中本起經 with that in the Vinayas, noting the many correspondences with the Mūlasarvāstivāda and Sarvāstivāda Vinayas. Therefore, I conclude that the biography transmitted in this sütra shares traditions with those sects.

\section{The Extinction of Form (rūpa): On kalahavivādasutta}

\section{Kishimoto Masaharu}

This study seeks to clarify the contents of the fourth and fifth chapters of the Sutta-nipāta. I take up "the extinction of form" in verse 872. The word "form (rūpa)" can be found in verse 909 and 950 in the fourth chapter and verses 1037, 1074, 1100. 1113 and 1121 in the fifth chapter. I have approached the topic by the following process:

(1) Clarifying the whole composition in "Quarrels and Disputes" (verses 862-877), which includes verse 872 .

(2) Looking into what verse 874 means: "Neither a man who thinks as he wishes, a man who thinks different things, a man who has nothing on his mind, nor a man who longs for extinction. The forms of the people who know this become extinct."

(3) Therefore, I have chosen other verses that seem connected with this. Especially "Know thoughts thoroughly and overcome a raging torrent" (verse 779) has made the meaning of verse 874 clearer.

No matter how many ways to think there may be in verse 874 , after all they are just "thoughts." Accordingly "the extinction of form" comes from abandoning any sense of thinking. 


\section{Pāli avajja- and vajja-}

Although Pā. vajja- always means 'sin, fault', it comes as a surprise that avajja-can mean both 'sin' and 'non-sin' in Pāli. Pā. vajja- 'sin' corresponds to Skt. varjya- 'to be avoided' and Pā. avajja- to Ved. avadyá- 'blameworthy; sin'. In this paper, I show that although avajja- and vajja- are ultimately derived from different roots, due to their formal and semantic similarity avajja- in its simplex forms was reinterpreted within Pāli as 'nonsin', i.e. as an antonym of vajja-. Taking parallel forms from Vedic, Ardha-Māgadhī, and Buddhist Hybrid Sanskrit into consideration, I clarify the etymology of avajja- and vajjaand explain the motivation behind the semantic change of avajja-.

\section{Dipamkara Buddha's Prediction in the Upasampadā-skandhaka of the Dharma- guptaka-vinaya}

Amano Shin

This paper analyses the story of Dīpamkara Buddha's prediction in the Upasampadāskandhaka of the Dharmaguptaka-vinaya. [T.22, no.1428, pp.782a-785c]. The unique characteristic of this description is that it does not appear at the beginning of the Buddha's biography. Through a close examination of this story, I show that its purpose is to explain the worship of the Buddha's hair and nails, and its merit to the upāsaka. Therefore this story is embedded in the Upasampadā-skandhaka of the Dharmaguptaka-vinaya in the account of the two merchants who became the first upāsakas. In addition, it is clear that the story of the two merchants who became the first upāsakas is linked up with Dīpamkara Buddha's prediction in the context of the Dharmaguptaka tradition. The various aspects of the evolution on this narrative are closely related to the stūpa cult in the Dharmaguptaka tradition.

\section{A Comparative Study of Accounts of Yāvajīika (-bhesajja) in the Six Vinayas}

InOuE Ayase

Yāvajīvika (-bhesajja) is a type of medicine defined in the Bhesajja-Khandhaka section 
of each vinaya as a general term for "medicine which may be possessed by the bhikkhu for his whole life." Moreover, when a bhikkhu who possesses yāvajīvika(-bhesajja) passes away, it is inherited by the sangha. Therefore, yāvajivika (-bhesajja) is never disposed of. The precise kinds of medicine encompassed by this term differ according to each vinaya. In this paper, I compare the versions of the story of the yāvajivika (-bhesajja) contained in each vinaya with the aim of clarifying the features and exploring the differences between these accounts. A close investigation of the contents and stories associated with the yāvajīvika (-bhesajja) of each vinaya reveals a pattern and originality that does not correspond to preceding research. In addition, the yāvajīvika (-bhesajja) stories are found in all the vinayas, which indicates that bhikkhus in those days were actively treating illness, and did not exclude sick bhikkhus from the sangha.

\section{The Original Meaning and History of bodhisatta / bodhisattva}

HOTORI Rishō

On the etymology of the term [Pāli] bodhisatta; [Skt.] bodhisattva, there is considerable disagreement among scholars of ancient and modern. Although many attempts have been made to explain the original meaning of that term, no one has yet been successful.

My research has been directed toward finding the true linguistic original meanings of bodhi and satta. The term satta, on closer study, proved to be not equivalent to [Skt.] sattva, but

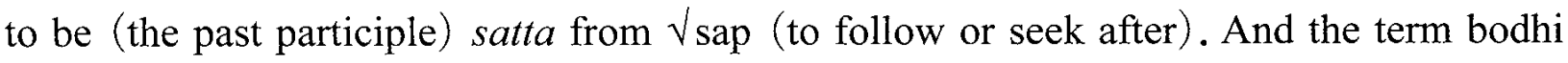
proved to be derived from the causative [Pāli] bodheti ([Skt.] bodhayati).

As a result, the original meaning of bodhisatta turns out to be "a seeking after the right way that waken me."

\section{The Sanskrit Manuscripts of the Samantabhadra-caryā-pranidhāna Preserved in} Kōkiji Temple

OKuKaZE Eikō

There are 17 Sanskrit manuscripts of the Samantabhadra-caryā-pranidhāna（普賢行願 讃) in the Kōkiji Temple (高貴寺) in Osaka. With collaboration from Kōkiji Temple, the author has been able to investigate these manuscripts. In this paper, a list of 17 manuscripts 
is given, together with general descriptions of some of the manuscripts.

\section{A Classification of the Mongolian Translations of the Astasāhasrikā-prajñā- pāramitā-sūtra}

UUDAM

The Asțasāhasrikā-prajñāpāramitā-sūtra was established in India around the first century $\mathrm{BC}$ and was transmitted to Mongolia through Nepal and Tibet. The Mongolian Buddhist sutras were translated primarily from Tibetan, as well as Uighur, Sanskrit and Chinese. The Aștasāhasrikāa-prajñāpāramitā-sütra was translated from Tibetan mainly during the North Yuan and Qing Dynasties.

The Sanskrit, Tibetan and Mongolian versions of the Asțasāhasrikā-prajñāpāramitā-sūtra are all composed of 32 chapters. However, there are differences between the old and new classification founded in 6 chapters, $1,3,7,10,12,25$, of the Mongolian and Tibetan versions.

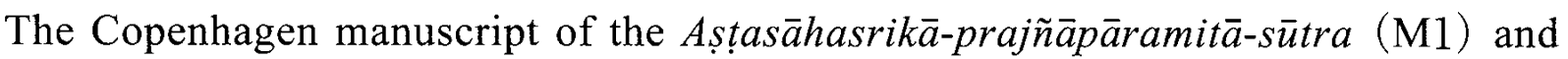
(M2) in Volume 113 of the Mongol Ganjur belong to the old classification. (M3) in Volume 108 completed in the Qing Dynasty and the Todu script Mongolian version (TM) belong to the new classification. In particular, M1 and M2 are considered as important references

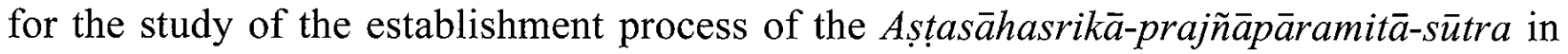
Mongolian.

164. A Study on the Correspondence between the Tathägataguhyaka and the Devarājapravara prajñāpāramitāsūtra

IkUMA Hiromitsu

The present paper points out that nine of the sixteen chapters of the Devaräjapravara prajñāpāramitāsütra (DRPP), equivalent to the sixth chapter of the Mahāprajñāpāramitāsütra, translated by Xuanzang 玄牀, correspond to the Tathägataguhyaka (TG). It appears that the DRPP is based upon the TG, or that they share a common source. 
165. Dating the Earliest Source that Attributes the Ratnagotravibhāga to Maitreya: Sanskrit Fragments IOL Khot S5 and Pelliot 2740 from Dunhuang

Kanō Kazuo

It was reported by H. W. Bailey that a Khotanese-Hybrid Sanskrit manuscript fragment from Dunhuang, IOL Khot S5 (abbr. S5) verso side, quotes verses from the Ratnagotravibhāga (abbr. RGV) and attributes them to Maitreya. S5 is the earliest text hitherto known that ascribes the authorship of the RGV to Maitreya. While Bailey dates the S5 verso side to the period between the end of the 8th century and the 11th century, we can now further specify the date of composition as some time between the second half of the 9th century and the 11 th century. Our rationale for this more specific terminus post quem is that the Chinese version of the Aparimitāyurjūānadhāran̄i (無量寿宗要経) written on the recto side of $\mathrm{S} 5$ is likely one of the numerous copies of the sūtra produced during (or shortly after) the reign of king Khri gtsug lde btsan, that is, during the first half of the 9th century. This fact is attested by two witnesses: Pelliot Tibétain 999 and the colophon of S5 recto side. There is also another Dunhuang Sanskrit fragment (Pelliot Chinois 2740) which quotes the RGV, and it is identified as the missing part of S5: the text of Pelliot 2740 recto precisely supplies the missing portion of 55 recto, and the two fragments are very similar in terms of size, material, and scripts.

\section{The Tathāgata-garbha Theory in the Mādhyamika and Yogācāra Schools}

Shiratate Kaiun

In Mahāyana-sūtras, it is said that all beings have tathāgata-garbha or buddha-nature within. The interpretations of this tathāgata-garbha, with regard to gotra-theory, are different between the Mādhyamika and Yogācāra schools. The Mādhyamika school, especially in the Abisamayālamkāra and its explanatory literature, thinks tathāgata-garbha to be identical with inherent-gotra (prakṛtistham gotram), not cultivated gotra (samudānitam gotram), while the Yogācāra school thinks tathāgata-garbha not to be identical with gotra, and that tathāgata-garbha is like emptiness which exists universally. 


\section{Nāgārjuna and $a v y \bar{a} k r t a$}

SAITō Akira

In Chapters 22, 25 and 27 of the Mūlamadhyamakakārikā (MK), Nāgārjuna deals with the traditional avyākrta (Pāli. avyākata) or "unanswered" questions in a slightly different way. Making a comparison between Nāgārjuna's discussion and those found in Pāli relevant passages, this paper draws the following conclusion: First, the avyākrta that Nāgārjuna refers to in $\mathrm{MK}$ is the 14-alternative one transmitted in the northern tradition of Buddhism. Secondly, one of Nāgārjuna's characteristic interpretations of avyākrta is found in his understanding of both śáśvata and aśáśvata as being based on pūrvānta or "the former end," and antavat and ananta as aparānta or "the latter end." Thirdly, apparently unlike the Buddha who is traditionally said to have refused to answer those avyākata questions, Nāgārjuna denies in MK all the 14 alternatives on the basis of the emptiness of all dharmas and entities. Or, it may rather be said in this connection that Nāgārjuna clarifies in words the intension of the Buddha's silence over the avyäkata questions.

\section{The Interpretation of Madhyāntavibhāga I-3 Quoted in the Prajñāpradipa: Avalokitavrata's Interpretation}

NIISAKU Yoshiaki

The third verse of chapter I (I-3) of Madhyāntavibhāgakärikāa (MAV-K) is one of the most important for the Yogācāra school, where the manifestation of consciousness and the concepts of what is to be apprehended (grāhya) and apprehender (grāhaka) are taught.

However, since Vasubandhu's Madhyāntavibhāgabhāsya (MAVBh), which is a commentary of MAV-K, is simple, it seems that a clear interpretation of this verse has not been obtained despite many researchers having referred to the work.

In this paper, I analyze MAV-K I-3 as quoted in Bhaviveka's Prajñāpradipa (PP) by referring to Avalokitavrata's Prajñāpradīpațikā (PPT), and compare MAVBh and PPT in terms of their interpretation of MAV-K I-3.

I analyze both works with a focus on the concepts of grāhya and grāhaka, and conclude that the interpretation of MAV-K I-3 taught in PPT is better in MAV-K's context. 
169. The Seven Aspects of Cause in the Yogācārabhūmi

Kondō Shinsuke

The seven aspects (ākāra) of cause (hetu) in the Yogācārabhūmi (瑜伽師地論) is the first formal definition of cause in the theory of mind-only (vijñāna-vāda), and is also the origin of the six aspects of the seed (bija) referred to in the Mahāyāna-samgraha (摂大乗 論) and the Cheng weishi lun (成唯識論).

In this paper, I make clear the meaning of each of the seven aspects by means of three different commentaries on the Yogācărabhümi. Two of the three were written in China by $\mathrm{Ji}$ (基) and Dunlun (遁倫). These two commentaries explain the seven aspects of cause as applied to the six aspects of the seed. However, the remaining commentary, written in India and accessible only as a Tibetan translation named Rnal 'byor spyod pa'i sa rnam par bshad pa (瑜伽行地解説), takes a completely different point of view and explains the texts in a unique manner. Comparing these three commentaries may prove highly significant and helpful in understanding the meaning of the seven aspects of cause.

\section{On Mahāyānasūtrālaṃkāra XX-XXI.43-61, Pratișṭhādhikāra}

UENo Ryūhei

(1) Regarding the title of Mahāyānasūtrālamkāara (MSA) XX-XXI.43-61 as pratișthāa, since all of the manuscripts that I examined contain the title pratisth $\bar{a}$, it is difficult to agree with Prof. N. Hakamaya's opinion insisting that it should be corrected to nișth $\bar{a}$ based on the Tibetan translation mthar thug pa.

(2) Based on the usage of the term in the Bodhisattvabhümi $(B B h)$, I argue that pratisth $\bar{a}$ should be understood as meaning 'base,' 'foundation' or 'support.' That is to say, in $B B h$, the ultimate support (pratiștha) serving as the foundation (pratisth $\bar{a}$ ) on which the selfand other-oriented practices of the bodhisattva are based (pratisth $\bar{a}$ ) are the 140 kinds of buddha-dharma.

(3) It may be hypothesized that the identification of MSA.XX-XXI.43-61 as pratisthā by the author of $M S A$ reflects this usage in $B B h$. In terms of the contents of pratiștha, however, we must be careful to regard MSA as an adaptation of $B B h$. That is to say, while $M S A$. XX-XXI.43-59 refer to the buddha-guna which develops 140 kinds of buddha-dharma as 
preached in $B B h$, the buddha-laksana expounded in MSA.XX-XXI.60-61, which is deeply related to the discussion of dharmadhätu-viśuddhi in MSA.IX.56-59, represents an usage of the term pratistha $\bar{a}$ that is unique to the MSA.

\section{The Interpretation of the Absolute Truth in the VIth Chapter of the Mahāyanasu- trālamkēara: With an Emphasis on the Influence of the IVth Chapter of the Bodhisattva- bhīmi}

HAYASHIMA Satoshi

The Mahāyānasūtrālamkkāra-țika and Sütrālaṃkāravrtti-bhāsya explain the absolute truth (paramārtha) in the VIth chapter of the Mahāyānasūtrālamkāra (MSA) as 1) thusness (tathat $\bar{a}$ ) and 2) the indiscriminate cognition (nirvikalpajūanna) that takes it as its object. This explanation is influenced by the explanation of truth/reality (tattva) in the IVth chapter of the Bodhisattvabhümi (BBh). First, the chapter title of MSA-VI echoes the chapter title of BBh-IV. Second, both the absolute truth in MSA-VI and truth/reality in BBh-IV are characterized by non-duality (advaya). Furthermore, truth/reality in BBh-IV is explained as thusness that is an object of indiscriminate cognition. Thus, we may conclude that the explanation of the absolute truth in MSA-VI is influenced by the explanation of truth/reality in BBh-IV.

Since truth/reality in BBh-IV encompasses conventional truth as well, however, truth/reality cannot be interposed as equivalent to the absolute truth.

172. A Few Problems of the Term tena (vikalpena) in the Trimsikikākārikā 17: From the View Point of the Interpretation of the Term abhütaparikalpa (vikalpa) in the Madhyāntavibhāgațikā

KITANO Shintarō

The aim of this paper is to consider the term tena (vikalpena) in the Trimsikikākāikā (TK) 17 from the perspective of interpretation of the term abhütaparikalpa (vikalpa) in the Madhyāntavibhāgațika (MVṬ). To date, many scholars have understood the term tena (vikalpena) in TK 17 in the sense of a subject of cognition. However, Rishō Hotori advanced the interpretation that this term means "field of consciousness," on the grounds that 
Vasubandhu uses the term tena to refer to "field of consciousness" in the commentary of the Mahāyānasūtrālamkāra (MSA) XI.13. Sthiramati does not discuss this problem in detail in the Trimśikābhāsya, but the term abhütaparikalpa is defined in the MVT by Sthiramati as abhūtam asmin dvayam parikalpyate 'nena vety abhütaparikalpah. Judging from the example quoted above, abhütaparikalpa (vikalpa) can have two interpretations: "subject of cognition" and "field of consciousness."

\section{The Influence of the Impure (aśubha) Meditation on the Philosophical Theory} of the Yogācāra School: With Special Reference to the Referent of "the Two"(dvaya)

Motomura Taiki

Generally, it is considered that the referent of "the two" (dvaya) in the Yogāaāra School is object (grāhya) and subject (grāhaka), which is seen in the Mahāyānasamgraha or the Madhyāntavibhāgabhāṣya. However, in the "Tattvārtha" chapter of the Bodhisattvabhümi in the Yogācarabhiumi, the referent of "the two" is different. In this chapter, it is said that there is vastu as the real existence of the outer world and prajñapti as verbal designation on vastu as unreal. Further, the referent of "the two" is the existence of vastu and non-existence of prajñapti.

Considering this fact, it can be thought that the Yogācāra school changed the referent of "the two" between the time of composition of the Yogācārabhümi and that of the Mahāy $\bar{a}$ nasamgraha or the Madhyāntavibhāgabhāsya. This paper aims at to clarify how the theory of the impure meditation influences the change in the referent of "the two" in the Yogācāra school.

\section{Apoha-theory and Semantic Field}

UEDA Noboru

Vasubandhu, in his Abhidharmakośabhāsya, denies the existence of a nāma (name) through which a voice (ghoșa, śabda) expresses its meaning (artha). Dignāga seems to be in line with Vasubandhu, and claims that it is the context or speaker's intention that determines the meaning (artha) of the voice (śabda). In his Pramanasamuccaya (-vrtti), Dignāga refers to two kinds of sāmānya: arthe sāmānya and śabde sāmānya. The parallel- 
ism between the two kinds of sāmānya that appears in the commentary on verse 5.33 is, it seems to me, important for understanding Dignāga's apoha-theory. The parallelism means that a śabda has many arthas: just as the voice (word) "akșa" has many meanings ("akșa" is a homonym), so the general word " $v r k s ̦ a$ " has many arthas of the particular words such as "śimśapa" and "paláśa." The present paper argues that when the meaning of a voice (word) is determined by the context of the speech, the voice (word) requires some semantic field (a group of words), where the word has the meaning (artha) of excluding others (anyāpoha).

\section{The Development of the Concept parārthānumāna in the Indian Buddhist Pramāna- school: With a Focus on Its Origin}

ONo Motoi

This paper aims to re-examine Frauwallner's generally accepted theory that the origin of the concept parārthānumāna can be ascribed to the Vādavidhi, a lost work of Vasubandhu, by considering the validity of Frauwallner's Vädavidhi-reconstruction, on which this theory depends. Frauwallner's assumption that Dignāga's Nyāyamukha was modelled on Vasubandhu's Vādavidhi can be accepted in general. But Dignāga's positive evaluation of Vasubandhu's Vādavidhāna in the Nyāyamukha and his criticism of the Vādavidhi in the Pramāṇasamuccaya suggest that the Vādavidhi probably did not adopt the three-membered syllogism, in contrast to the Vādavidhāna and the Nyāyamukha. This means that Frauwallner's reconstruction of the Vādavidhi must be modified in some crucial points. As a result, the part of the Nyāyamukha which is apparently regarded as the origin of the concept parārthānumāna cannot be traced back to the Vādavidhi with certainty. The conclusion of this paper is that the origin of the concept parärthānumāna must be ascribed to Dignāga's Nyāyamukha itself, not to Vasubandhu's Vādavidhi.

\section{6. svasamvedana and dvairūpya: Cognitive Structure according to Dignāga}

KATAOKA Kei

Previous studies interpret PS (V) I 9cd as describing a Sautrāntika view that (intentional) self-awareness (svasamvedana) is the result (phala). This interpretation is not sup- 
ported by a straightforward reading of the original Sanskrit text. Dignāga's model described in PS (V) I 9d emphasizes the point that cognition of an object is objective and not subjective: an external object such as white is cognized in the same way in which it enters the cognition, namely as white. The model of svasamvedana and dvairüpya depicted here is incompatible with the subjective model, i.e. the view that an object is cognized in accordance with self-awareness. In order to interpret PS (V) I 9d as describing the subjective model, one has to resort to forced reinterpretations. For example, Jinendrabuddhi interprets mìyate as niściyate, and tena as tatsādhanay $\bar{a}$ svasamvidā. This is also the case with the passage jūānasvasamvedyam api svarūpam anapekșa, which, according to Dharmakirti, is to be interpreted as sann api grāhakātmā. In other words, one needs to resort to interpretative devices in order to squeeze out the view that an object is subjectively cognized in accordance with self-awareness. A straightforward reading, however, suggests the opposite. There is no need for us to resort to complicated exegetical devices. One can simply interpret PS (V) I 9cd as describing the objective model, i.e. a Sautrāntika view that the cognition of an external object is the result.

\section{Dharmakīrti on Abhisamaya Meditation}

KIMURA Toshihiko

Dharmakirti (c.550-620) defined Buddhist yoga as an intuition together with the other intuitions: sense perception, mental cognition (mānasam) and self cognition (svasamvedanam). In kk.281-286 at the Chapter of Intuition of the Pramāṇvārttika, he relates thus: "Formerly we defined the intellect of yogins. Their intellect consists of meditation and appears clearly without secular judgments," and so on. He noted that contemplation is divided into the erroneous influenced by fear, sorrow etc. and the true having the true object of the four noble truths. The problems of Dharmakīrti's statement consist of "having stated formerly" (prāg uktam) regarding the definition of the intellect of yogins and its textual source.

In the Pramānasiddhi chapter there is no statement concerning yogic perception. We must suppose the reference in the Nyāyabindu, I, 11, "and the fourth sort of intuition is meditational cognition produced from the top of the culmination of meditation against true objects" (bhūtārthabhāvanāprakarṣaparyantajạ̣ yogijñānaṃ ceti)

Vinitadeva commented this statement on the basis of the traditional Buddhist system of 
meditation, that is, abhisamaya meditation. According to him, the meaning of true objects (bhūtārthāh) is the four noble truths (āryasatyāni); that of culmination (prakarșah) is top abhisamaya consisting of heat degree and so on. The word 'paryantah' (end) means worldly top yogins (agradharmāh), he says.

The system of abhisamaya meditation is based on the Abhisamayālañkāra of Maitreya (cf. III, 12-15). Vasubandhu inherited it in his Abhidharmakośa, in the sixth chapter. Above all, his statement that the four noble truths correspond with the stages of abhisamaya meditation is very important $(\mathrm{k} .2 \mathrm{~b})$. In regard to the four stages of the meditation, see kk. 25b28a as well as kk.17-19. Dharmakirti accepted the traditional system of meditation from Vasubandhu's Abhidharmakośa.

Dignāga in his Pramāṇasamuccaya, I, 6b defined yogic intuition as pure intuition, not mingled with words of teachers or sacred books according to his discipline of pure perception (nirvikalpakapratyakșam). On the other hand, Dharmottara interpreted the Nyāyabindu I, 11 by the theory of clear presentation (sphutābhatvam) which was inherited by later Buddhist schools. The statement "prāg uktam" was sometimes supposed to point out the Pramānasiddhi chapter. But all these were erroneous.

\section{A Study of the Guhyasiddhi: Some Remarks on the Additional Parts of the Tibet- an Translation}

YoKOYAMA Hiroaki

This paper focuses on the difference between the Sanskrit text of the Guhyasiddhi and its Tibetan translation, which is enlarged. It has already been pointed out that it has a Śaiva influence which is not seen in the additional parts of the Tibetan translation. I examine some possibilities for the cause of this difference, and conclude that the Tibetan translator may have had a different version of the Guhyasiddhi than that available to us in Sanskrit. This might have been caused by the insertion of interlinear notes which came to be incorporated into the main text. 


\section{The Funeral Rite Prescribed in Padmaśrīmitra's Mandalopāyikā}

TANEMURa Ryūgen

Padmaśrimitra's Mandalopāyika , of which the codex unicus is preserved in the Tokyo University Library, prescribes the funeral rite in the last chapter Antasthitikarmoddeśa. This short paper mainly reports on the textual parallels between the Antasthitikarmoddeśa and the Nirvrtavajrācāryasatkārakrama, which is another funeral manual contained in the Vajrācāryanayottama. In addition to these textual parallels, from the facts that the Guhyasamāja and the Catuspițha are scriptural authorities for the Mandalopayik $\bar{a}$ and that the Vajrācāryanayottama contains texts of important works of the so-called Ārya school of the Guhyasamāja, it may be inferred that the Antasthitikarmoddeśa is related to the system of the Guhyasamāja Ārya school.

\section{The Flames on the Shoulders of Dipamkara and the Liuduji jing}

MURAKAMI Tōshun

This paper is an attempt to examine Buddhist texts on the flame shoulder 焰肩 of Dípamkara found in Gandhāran Buddhist art and Kapisi Buddhist sculpture. However, direct representation of the flame shoulders of Dipamkara does not exist in Buddhist texts. I investigated, therefore, expressions for light in the texts that discuss the body of Dipamkara. In this regard, there is a representation of flaming shoulders in the Liuduji jing 六度集経.

The Liuduji jing was translated in the third century. Thus, the Dipamkara statue with flaming shoulders also can be considered as already existing in the third century. In addition, the old part of the Liuduji jing is considered to have been established in the second century, but there are several theories about the chronology of Kapisi Buddhist sculpture. I conclude that the period from the second century to the third, as advocated by Dr. J.Meunié and Dr. K. Tanabe, is the most likely time of origin of this motif.

\section{Old Tibetan Translator shus chen gyi lo tsā ba}

Persons prominent as old Tibetan (Tubo) translators (shus chen gyi lo tsā ba) are 
known as the $\mathrm{sKa} / \mathrm{Ka} \mathrm{Cog}$ Shan gsum, i.e. three translators, namely $s \mathrm{Ka} / \mathrm{Ka}$ ba $\mathrm{dPal}$ brtsegs, Cog ro Kluhi rgyal mtshan and sNa nam Shan Ye śes sde, who were enumerated and designated as thus in later periods, and also designated as lo tsā ba gshon [pa] gsum. In the $h K h r u \dot{n} s$ rab/rabs which describes the reincarnation series of Rol pahi rdo rje (171786), the third lCan skya incarnation of the later dGe lugs pa, a work written by dKon mohog hjigs med dban po (1728-91), the second hJam dbyans bshad pa incarnation of the same sect, the text enumerates $\mathrm{dPal}$ brtsegs as the fourth incarnation, and quotes another hKhruins rabs and Than yig in its interpretations. As the latter material is the Padma than $y i g$ which belongs to materials of rÑn ma pa traditions, in this paper I would like to present this material and the bKah thain sde lina belonging to the same sect, and investigate the import of these two sources for the traditions of the above mentioned three translators.

\section{Svātantrika and the dbu ma pa'i thun mong ma yin pa'i khyad chos}

Fukuda Yōichi

One of the chief themes of the Mādhyamika philosophy of Tsong kha pa (1357-1419), the founder of the Gelugpa school of Tibetan Buddhism, is the so-called supreme and unique teaching of the Mādhyamika school ( $d b u$ ma pa'i thun mong ma yin pa'i khyad chos). This teaching suggests that dependent-arising and emptiness of intrinsic character should belong to the same subject.

This teaching is also described in Nāgārjuna's Mūlamadhyamakakārikā (root verses on Mādhyamika theory), and thus should be accepted by every Mādhyamika. However, Tsong kha pa asserts that the ontology of the Svātantrikas could not admit this special teaching because it admits the intrinsic character at a conventional level, and this teaching insists upon the contradiction between intrinsic character and dependent-arising.

I attempt to elucidate this contradiction between Tsong kha pa's two assertions through a careful reading of his first masterpiece, Lam rim Chen mo. 


\section{The Philosophical Standpoint of Phya pa chos kyi seng ge in His Tshad ma yid kyi mun sel}

NishizAWA Fumihito

Phya pa chos kyi seng ge (1109-1169) is one of the greatest scholars of gSang phu ne'u thog which was closely related to the bka' gdams pa tradition. He is especially famous for his original pramāṇa text Tshad ma yid kyi mun sel (abbr.YMS), sometimes called "Cha/ Phya/Phywa bsdus" in later periods. The present paper offers an analysis of the philosophical standpoint of Phya pa based on YMS, from which are drawn the following conclusions:

1. The basic philosophical standpoint of Phya pa found in YMS is that of Mādhyamika philosophy, not Yogācāra nor Sautrāntika, since Phya pa explicitly refutes these two tenets in YMS $1 b 9-3 b 2$. The characteristics of his philosophical views can be summarized in the following two points:

(1) Phya pa calls himself Nirākāravādin who recognizes the existence of an external object (cf. YMS 8a7-8: kho bo cag rnam pa med par phyi rol gyi don rig par smra ba).

(2) Phya pa recognizes the emptiness (śūnyatā/ stong pa nyid) established by the neither one nor many (cig dang du bral) argument (cf. YMS 2bl, etc).

2. Although some scholars insist that Phya pa follows the Vaibhāșika in the level of conventional truth, there is no obvious evidence that supports this interpretation. In fact, Phya pa recognizes self-cognition (svasamvedana/ rang rig) as one of the four kinds of pratyakșa, which the Vaibhāṣika never accept.

184. The Completion Stage in the sNgags rim chen mo of Tsong kha pa: bodhicitta in the Kälacakra-tantra

ISHIBE Michiaki

The bodhicitta characterized as bde stong dbyer med (bliss-emptiness and inseparability) in the Kălacakra-tantra is an amalgamation of the bodhicitta of prajñ $\bar{a}$ and the bodhicitta of means. The roots of the formation of these two types of bodhicitta are identifiable as extending back into the early stage of Mahāyāna.

The process of creating ritual manuals concerned with bodhicitta as bde stong dbyer med can be understood as having been based on physiological theories. Among those theories 
deployed in the creation of ritual manuals, various texts present a range of explanations for the key factor of rtsa (channels). In this paper I have considered the connection between bodhicitta characterized as bde stong dbyer med as explained in the sNgags rim chen mo, and the channels within the subtle body, as it occurs within the process of creating ritual manuals. After comparing the intricate and diverse features of the channels in the sNgags rim chen mo, Hevajra-tantra, and Kälacakra-tantra, it was learned that a feature held in common among these three texts is the upward direction of the bodhicitta of prajñ $\bar{a}$ in the channels, and the downward direction of the bodhicitta of means.

\section{The dẹka niṣkāya dharma Transmitted to Mi la ras pa via Ras chung pa}

\section{WatANABE Atsuko}

The famous eleventh-century Tibetan yogin Mi la ras pa bZad pa'i rdo rje (10401123/1052-1135) himself left no written records of his life or teaching. His songs and life story were passed down orally, eventually to be written down in many different versions. To understand his ideas, one must turn to the writings of his immediate and later disciples.

Mi la ras pa's main teacher was Mar pa Chos kyi blo gros (1002-1097) and his main disciples are sGam po pa bSod nams rin chen (1079-1153) and Ras chung pa rDo rje drags pa (1085-1161). Although Ras chung pa was a student of Mi la ras pa, he also transmitted some Tantric teachings from India to Mi la ras pa, including the dāka niskkaya dharma. Actually, Mi la ras pa had already reaceived an incomplete transmission of this dharma from his teacher Mar pa, but later sent his own disciple to India to bring back the rest of the dāka niṣkāya dharma. Here I elucidate one aspect of Mi la ras pa's Buddhist thought by analyzing Mar pa and Rachung pa's oral/secret transmission of the dīka niṣkāya dharma.

\section{A Study on the Formation of the Five Evils Paragraphs: A Comparative Study of Zhaijie qingjng and $E$}

XIAO Yue

This is a study of the formation of the Five Evils paragraphs 五惡段 in the Dà âmituó jīng 大阿彌陀經, the oldest version of the Larger Sukhāvatīvy $\bar{u} h a$ Sutra. This problem is approached in two ways. 
First, I undertake a comparative study of the terms zhäijiè qingjìng 齋戒清淨 and $\grave{e}$ 惡 as they appear in the Five Evils paragraphs to verify that the Five Evils paragraphs were created by the author (s) of the Dà āmituó jing. Second, I perform a comparative study of the two versions of the Five Evils paragraphs that appear in the two oldest versions of the Larger Sukhāvatìvyūha, the Dà āmítuó jīng and the Pingdèng jué jīng 平等覺經, to verify that the term zhaijiè qingjìng is directly related to the formation of the term jingtŭ 淨土.

\section{The Biography of the Tang Monk Daoyin in the Dunhuang Manuscripts}

Dingyuan (WANG Zhaoguo)

Daoyin (668-740) was a Buddhist monk active in the Kaiyuan period of Xuanzong's reign. Among the books he wrote is the Elaborate Commentary on the Imperial Exegesis of the Diamond Sutra. A very detailed biography of the monk is included in the fifth fascicle of the Biographies of the Eminent Monks Written in the Song Dynasty (compiled in 988). This biography was composed 250 years after Daoyin's death. Thus its credibility is an obvious problem. As a matter of fact, some references to this monk are scattered in the Dunhuang manuscripts and cannot be found in the aforementioned Biographies; they are extremely valuable for a study of Daoyin's life.

By using newly found references, this paper offers a fresh investigation into Daoyin's life. It shows that Daoyin might have lived in the Great Fortune-Offering Monastery (Da jianfu si 大薦福寺）in Changan in the sixteenth year of the Kaiyuan period (728) and had a quiet life for over a year due to poor health until the twenty-third year of the same period (735), and that in the last years of his life he was chosen as one of the ten Great Palace Temple Monks (shidade 十大徳) and participated in the Buddhist events organised in the Palace Temple. Daoyin was an important figure of Chinese Buddhism during the Kaiyuan period, and therefore he deserves further studies. 


\section{Locating the Thought of the Yuánming lùn (円明論) in the History of Chan Bud- dhism: Understanding States of Mind by Looking at the Context of Sütra Discursive Texts and Metaphors}

YANAGI Mikiyasu

Chan thought is typified by two main tendencies, the liberal use of metaphors and fre-

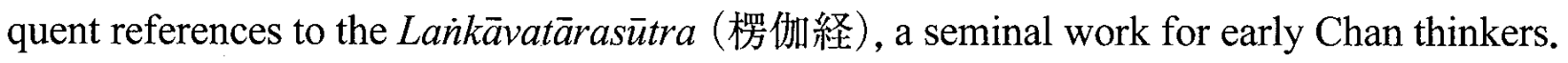
This paper will examine the Yuánming lùn, paying special attention to the use of the concept of citta as it appears in the "water-mirror" metaphor. Here citta and hrdaya are brought together in a single integrated concept, which reflects closely the doctrinal understanding of the Northern School. In this way, the Yuánming lùn is presenting something new, in contrast to a work like the Errùsixing lùn (二入四行論), which clearly uses citta with the same understanding as that in the Làikāvatārasūtra. The Yuánming lùn displays a change in the understanding of citta to hrdaya, thus showing its importance as a transitional work in the history of Chan thought.

\section{9. Ǔisang (義湘)'s Perspective on Language}

PARK Boram

Is it possible to express the Buddhist ultimate truth or state such as tathatā or nirvāna by language? In this context, what is language? This paper aims at investigating this from the standpoint of Ǔisang's Hwaŏm theory.

His works have a mix of views on the effability and ineffability of tathatā or nirvāna. However, it is not because the objects of expression, for example tathatā or nirvāna, are something ulitimate, but rather that tathatā or nirvāṇa are not to be expressed just as all dharmas are not to be expressed. At the same time, all dharmas are included in the net of Śākyamuni's teachings and so lie in words, which means everything can be taught by words.

Effability and ineffiability are in the relation of the middle path which is the characteristic of dharma-nature and both have no fixed self-nature. Thus everything could be effable or ineffable in accordance with necessity (須).

These two which are the characteristics of dharma-nature appear as "My five-foot body 
(吾五尺身)," namely our own body from a viewpoint of Ǔisang. Therefore, my five-foot body as a rising of dharma-nature is nothing but words when words are given and also my five-foot body is nothing but silence when it is silent.

\section{Rethinking Shinran (親鷿)'s Idea of Exoteric and Esoteric}

CHEN Miin-ling

This paper deals with Shinran's idea of Exoteric and Esoteric in the Transformed Body and Land (Keshindo 化身土) chapter of his Kyōgyōshinshō 教行信証. Although Shinran's explanation quotes that of Shandao in his commentary on the Guan jing 観経, he changes the meaning by eliminating some words. He concludes that the sixteen visualizations of the Guan jing are nothing more than an expedience of skillful means.

For Shinran, however, the expedience the expedience is not to be conceived of as neglect but as an expression of the view of Own Power (jiriki 自力) to the faith of Other Power (tariki 他力). This ideology is evident when Shinran associates the eighth visualization with the occurrence of the mind of faith. With this awareness, Shinran finds nothing but the motive power from the Sea of Compassion of Amida Buddha's vow latent in both meditation and recitation of the nembutsu.

Shinran's emphasis on the adoring mind is just like that of Shandao, who combined the goodness of religious and moral practice into the Paragraph of Xinjingyuan 欣浄縁 in the Preface to his Commentary on the Guan jing. With such an understanding, Shinran asserts that the Guan jing differs from the Larger Pure Land Sutra.

\section{The Bruno Petzold Collection in the Harvard-Yenching Library}

ANNAKA Naofumi

The Harvard-Yenching Library has many materials concerning Japanese Buddhism. The Bruno Petzold Collection holds an important position with regard both to the quality and quantity of its contents.

Bruno Petzold was born in 1873 in Germany, and came to Japan in 1910. He had been teaching German at the Daiichi High School from 1917 through 1943 and also taught at Risshō University, Chūō University and Seikei High School. During those days he studied 
Buddhism under Daitō Shimaji and Shinshō Hanayama. He became a minister of the Tendai sect 天台宗 and had been in Japan for 40 years when he passed away in 1949. He wrote a number of academic books and essays on Buddhism. He collected more than 10,000 Japanese and non-Japanese books, and wished to build a library with those books at Mt. Hiei 比辡山. After his passing, however, his son sold his books. 3,500 non-Japanese books were purchased by Canberra University, 2,800 non-Japanese books went to Kokugakuin University, and 6,000 Japanese books and 500 scrolls went to the Harvard-Yenching Library.

Many of his 6,000 Japanese books have already been published in the volume Early Japanese Books in the Harvard-Yenching Library. But many of 500 scrolls have not yet been published; therefore I study those scrolls in this essay.

\section{The Coming into Being of Worlds in the Avatamsaka Sutra and Stephen Hawk- ing's Theory on the Universe}

JiN Young-You

This research paper is based on the Coming into Being of Worlds 世界成就 in the $A v$ atamsaka Sutra, establishment of the world in the Qishi jing 起世經, Genesis in the Bible, and S. Hawking's theory about the universe.

Since the publication of The Grand Design a book by S. Hawking, countless online discussions have been taking place on the creation of the universe by God and many have been voicing criticism. Some support the theory that God created the universe, while others argue that God is useless, in support of the theory that evolution took place based on the law of nature. It seems like the Buddhist circle doesn't feel the need to get involved in this argument. The universe viewed by Buddha in the Qishi jing is not limited to Earth, but is the multiverse referred to by S. Hawking and is thus infinite. Therefore, a discussion should take place after deciding which world's beginning and end will be the topic. I believe making an issue of the beginning and end of a universe that has no beginning and end is an extremely meaningless dispute. What is important in Buddhism is not the very beginning or creation, but the matter of how we should accept the universe and move it together. According to the Coming into Being of Worlds of the Avatamsaka Sutra, what builds the universe is the activities of all living things, which is described as the karmic activity of all beings, one of the causes of the creation of the universe. It is also said that the most impor- 
tant causes are the power of all bodhisattvas' vows and the flowing forth of all Thus Come Ones' good roots. Questioning about the beginning or creation of the universe is an interesting topic for discussion if it is specifically about the Earth, which is an 'extremely small universe.' However, it becomes insignificant when considering the multiverse. In The Grand Design S. Hawking says the creation and change of the universe is not simply because of a single cause, but is infinitely progressing based on multiple, various rules. Although there is a slight difference, the views of S. Hawking are quite similar to the Buddhist view of the universe.

\section{How to Treat Digital Media in the Field of Indian and Buddhist Studies}

NAGASAKI Kiyonori

Recently, digital media have been becoming increasingly important not only in the humanities in general, but also in Indian and Buddhist studies. This article aims to describe how to treat digital media in such a situation. At first, it focuses on a difference between basic encoding and highly structured encoding in the case of the distribution of digitized texts referring to TEI guideline. In particular, the problem of variant characters reveals to us explicitly that it depends on not only distributors of the texts but also their recipients. We must also notice several problems of sustainability. The sustainability of data is very important, and free license has a key role in it. On the other hand, several problems of free license arise in academic societies. What must be known by users of such digitized data? Several possibilities, such as cooperation with the other fields and evaluation of digitization works in the near future, are also discussed.

\section{Shōgoin 聖護院 and the Regional Organization of the Honzan 本山 sect}

\section{MIYAKe Hitoshi}

In this report, I will consider the development of the Honzan sect and its head temple, Shōgoin, during the early modern period by looking at its early inclusion of regional sacred mountains, its later transition, and its eventual rebirth in the Meiji period. 
195. ni⿱龴-kray ${ }^{i}$ 一ヴェーダ祭式における自己の買い戻しの概念について一

大島 智靖

ソーマ祭において潔斎（Dỉksāa) を行った祭主は，象徽的に「胎览」となり， また「供物」となって神々に自身を捧げねばならない，捧げられた自身はその後 の動物犠牲祭における犠牲獣を以て「買い戻」される（動詞 nis-kray ${ }^{i}$ ) という思想， 即ち 'ätmaniṣkrayana’ がブラーフマナ文献（br.）に見られることは従来言及さ れてきたが, br. 全ての用例が総合・分析されたわけではない，本稿は，br.の全 用例を基にして「買い戻し」の概念を考察したものである. その結果，この概念 は ‘ātmanișkrayana’’のみならず様々な場面で適用され，一定の役割を果たして いたことが明らかになった。

ソーマ祭の基本形となる Agniștoma では，3つのタイプが観察された。(1)潔斎 において捧げた自己の買い戻し(犠牲獣による), (2) Bahiṣpavamānastotraにおける， 象徴的天界上昇において振り落とした骨格の買い戻し（1)とは別の犠牲獣によ る)，(3)祭官への報酬寄与における，一時的に祭官に預けた自己の身体部位や生 体諸機能の買い戻し（実際の報酬品による）である。(1)(2)において，祭主は象徵 的に天界に行く，人が天界に行くためには必ず何らかの犠牲つまり喪失があり， 「買い戻し」はそれを取り戻す行為として必須のものであったと考えられる。こ れは祭主が最終的に天界へ行き（実際に死ぬ），天界で完全な状態になるために， 現世でも完全な状態でなくてはならないということであろう。一々において律義 に互譲がなされている点も注目すべきである，(3)の意義については更なる検討を 要する.

また Kāmyeștii（Kāmyapaśu を含む）においても各々に応じた「買い戻し」があ るが，そこにAgnisțtomaに扔ける「自己の買い戻し」と同様のタイプは，祭式の 性格上見出し難い. しかし Śatapatha-Brāhmana $の$ 新満月祭の補遺的解説に Agniștoma のそれと並行する部分があり，注目に值する。

\section{Veda 文献における動詞 $a^{\prime} t i-p a v^{i} / p \bar{u}$}

西村 直子

本稿は, Veda 文献に見られる動詞 $a ́ t i-p a v^{i} / p \bar{u}$ の語形，用例，分布の分析を通じ て語義の展開を跡づけることを目的とする．本動詞は最古の Rg-Vedaにおいて 
「(Soma が)（清めの道具などを）越えて清まる」の意で用いられていたが, ヤジュ ルヴェーダの散文以降は特定の Indra 神話と結びつけられて Sautrāmaṇī 祭を巡る 議論に頻出する。その文脈では祭主の身体が清めの道具と見立てられ，「Somaが 人を通過して清まる」，即ち飲んだ Soma を下痢・嘔吐などで排出するという特 定の身体症状を指す語として用いられる。動詞 $p a v^{i} / p \bar{u}$ は，RV 以来，現在直説法

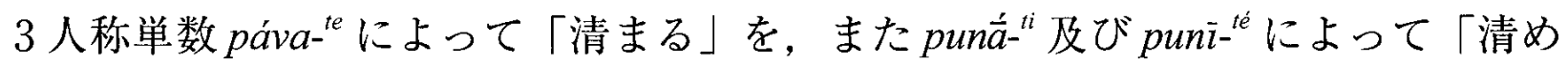
る」をそれぞれ意味している．使役形には paváya- ${ }^{\text {tite }}$ の他に pāvaya- ${ }^{\text {tite }}$ があり，

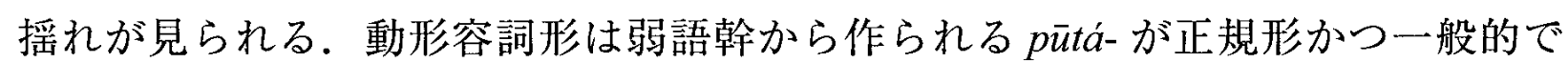
あるが，前緅り áti を伴った場合にのみ，ati-pavita-を伝える文献がある（（áti-） pavita-の由来は明らかにできないが，Brugmannの法則を前提に求められる本来 の使役形 paváya- - $^{t i t e}$ を出発点とする可能性は排除できない. pavilpū の使役形に áti を伴う例は，Maitrāyanīya 派を中心とする Śrautasūtraに atipāvayati が僅かに見ら れるのみであり，ati-pavita-は使役語幹 pavaya-を伝える Taittiriya 派に影響され たものか，又は本来的な語幹の形が残ったものと推測される，atipavita-の初出は Kāthaka-Samhitā (散文), 正規形の átipūta- は sómātipūta-の形で, Śatapatha-Brāhmana 以降に現れる. sómātipūta- は sómātipavita-（ŚBK，JBなど）と同様「その 人を通過して清まったSomaを持つ」という形容詞として用いられるが（Bahuvrīhi），前者は特異な語形を含む後者を Mādhyandina 派が置き換えたものと考えら れる。

197. 叙事詩『マハーバーラ夕』におけるスータについて

一古伝承におけるスー夕像の変遷一

石原 美里

「スータ」という語はこれまで「御者」「「吟誦詩人」と訳されることが多かっ たが，多くのスー夕に関する叙述を収集・分析すると，その人物像は非常に曖昧 で一貫性がなく，「御者」,「吟誦詩人」という一言では片付けられない複雑さを 孕んでいる，本研究では，『マハーバーラ夕』に登場するサンジャヤという王の 側近であるスータが，ヴェーダ文献に見られるスータ像をある程度反映している ものと仮定して，そのスータ像の変遷を追った。

このヴェーダ時代におけるスータ像は,『ヴィシュヌプラーナ」の中に収めら れているプリトゥ王神話におけるスータ起源譚にも反映されている。そこにおい 
てスータは，王のするべき行いを規定するような権力を有する王家の高官として 描かれており，それを便宜的に「古型」と位置付けた。その後この「古型」は， バラモンらがスータを彼らの構想する 4 ヴァルナ社会に組み入れようとする際 に，混合ヴァルナ身分としてのスー夕の裏付けとして椂々に応用されたと考えら れる，その一方で,スータが現実社会に存在しなくなった時代、『マハーバーラタ』 の最終改編としてスータ・ウグラシュラヴァスの語りの枠が導入される。この際, 『マハーバーラタ』の編者らは，その語り手として「放浪の吟誦詩人」という新 たなスー夕像を創り上げたと推測される，その新しい語りの枠はいくつかのプ ラーナ文献にも採用され, その結果, 放浪の吟誦詩人的スー夕像と, 古い伝承に おける王家の高官的スー夕像が同文献内にも併存することになったと結論付け た。

198. ブラフマーからシヴァヘ ープラーナ聖典に見る両性具有的創造者の神話一

澤田＼cjkstart容子

ブラフマーによる創造神話の中に男女に分裂する創造者が登場する。それはシ ヴァの化身であるアルダナーリーシュヴァラの前身とされる，本稿は，プラーナ 聖典に記述されている神話を取り上げ内容を精査することによって，男女に分裂 する創造者の神話の発展過程を明らかにすることを目的とする.

12 のプラーナ聖典の中には，ブラフマーとルドラそれぞれが男女に分裂して 創造を行なう神話が収められている。この 2 者の神話には，(1)創造者の登場する 原因，(2)創造者が男女に分裂する描写，(3)マヌとシャタルーパーの系譜，という 3つの一致した記述があり，同型の神話と考えることができる．さらに，マヌと シャタルーパーの系譜に関してルドラが男女に分裂する神話の内容に矛盾がある こと，及びブラフマーが男女に分裂する神話の中に女性半身が女神になる記述が 見られないという点から，ブラフマーが男女に分裂する神話はルドラが男女に分 裂する神話に先行して作られた可能性が高いということができる.

このように，元来ブラフマーによってなされていた男女に分裂して創造を行な うという役割をルドラが引き受けたのち，分裂した女性半身が女神であるとする 形態が登場したため, アルダナーリーシュヴァラはシヴァとその配偶神から成り 立つ神という姿を持つことになったと考えられる。 
199. Meghadūta における河を女性に見立てる比喻について

川村 悠人

雨季の風情，とりわけ雨季における別離の心情の描写は古典サンスクリット文 学において好題であり, カーリダーサ（Kālidāsa，4 世紀から 5 世紀）の代表作 Meghadūta（『雲の使者』）もそれらを主題とした作品である. Meghadūtaは, 妻 との別離に苦しむ主人公ヤクシャが雨季の到来を告げる雨雲を見て妻への想いを 掻き立てられ，その雲に音信を依頼する，という構造を基本とする．Meghadūta 前半部において, 妻がいる都アラカーまでの旅路を雲に語る中で, ヤクシヤは雲 が旅路で出会うであろう河の種々の特徵を女性のそれに度々比喻している (Meghadūta 24, 28-29，40-41).つまりこのことは，ヤクシャが頻繁に河を女性に 見立てていることを意味し，必然的に，その河と関係を持つ雲を男性に見立てて いることを意味する。ヤクシャは, Meghadūta 前半部において雲と河を男女に見 立て, 雲と河の愛を語っているのである。このような事柄をヤクシャが雲に語る ことについて，木村 [1965］は，河という女性との旅路の恋を楽しむことをヤク シャが雲に勧めていると解釈する。しかし，Meghadūtaの主題を考慮する時，木 村氏の解釈は作者カーリダーサの真意を汲み取っているとは言えない.ヤクシャ は雲と河に自分と妻を重ね合わせ, 雲と河の愛を語ることで妻への情欲や切望を 吐露している．言い換えれば，カーリダーサは雲と河の愛を描くことによって， 別離に苦しむヤクシャの心情を巧みに表現しているのである，本稿では，河を妻 に見立てることで別離する夫の心情を描くというカーリダーサの手法を明らかに する。

\section{0. 仏教の勝利かシヴァ教の勝利か}

一9世紀カシュミールの詩 Kapphināābhyudaya 研究一

横地 優子

Kapphināabhyudaya は 9 世紀カシュミールの詩人 Śivasvāmin によって著された長 編詩である. 2007 年に龍谷大学よりこの作品の新しい校訂版が出版され，その 研究は新たな段階を迎えた，その第一歩として，本論文では，従来仏教詩である と考えられてきたこの作品は，そのような表面的な意味に加えて第 2 の意味レべ ルを備えており，そこでは仏教とシヴァ教の競合，最終的なシヴァ教の勝利が意 
罒されていることを分析する。

201. ヴィーラバッダの『アーラーハナーパダーヤー』: 予備報告

河崎 豊

ヴイーラバッダが Samvat 1078 年に著したとされる『アーラーハナーパダー ヤー』は、ジャイナ教の所謂「アーラーダナー文献」と呼ばれるジャンルに包摂 される文献の一つだが，本文献に関する先行研究は，管見の限りでは皆無である。 本稿は当該文献の本格的研究の為の予備調查として，主に以下の点を指摘した： （1）『アーラーハナーパダーヤー』全 989 詩節中, 786 詩節が空衣派代用聖典の『バ ガヴァティー・アーラーダナー』と対応し，構成そのものも『バガヴァティー・ アーラーダナー』を完壁に踏襲していること（2）白衣派聖典との関係では特に 『バッタパリンナー』との対応が顕著であること（3）『バガヴァティー・アーラー ダナー』『バッタパリンナー』双方に対応関係が見られる場合，ヴイーラバッダ は後者（に近い）読みを示すことが強いこと（4）『アーラーハナーパダーヤー』 本文中に，『バガヴアティー・アーラーダナー』を明らかに指すと考えられる記 述が登場することから，ヴィーラバッダは『バガヴァティー・アーラーダナー』 について知っていた事は恐らく確実であり,そして『アーラーハナーパダーヤー』 を作成するにあたって，『バガヴァティー・アーラーダナー』を大々的に利用し た可能性もかなり高いと考えられること．以上を指摘した後，具体的に若干の対 応事例を列挙し，そこに見られる種々の問題点を議論した。

202.タットヴァ経におけるニクシェーパ

上田 真啓

ジャイナ教の聖典期には，聖典における単語のひとつひとつを正確に理解する ための「解釈方法 (anuyogadvāra)」というものがある.どのような方法かという と, 単語のもっているいくつかの性質を, 解釈の可能性, すなわち選択肢として 列挙し，それらの中から当該のコンテキストに見合った選択肢を選びとって，単 語の意味を特定するという方法である。主に niryukti などの注釈文献において見 られるその方法は，ひとつではなく，列挙される要素の組み合わせなどによって いくつかのパターンが存在した。そのなかでも特に重要視されたのが，「名称 
(nāma)」「表象（sthāpanā)」「実体（dravya）」「状態（bhāva）」という組み合わせ のパターンであり，それは特に「ニヤーサ (nyāsa)」，あるいは「ニクシェーパ (nikșepa)」という名前で呼ばれた，そういった聖典解釈法のひとつとしてのニク シェーパが，のちにジャイナ教の認識論・論理学に関わるテキストにおいて，そ の体系の中に位置づけられ, 場合によってはプラマーナ（pramāṇa）とナヤ（naya） と並ぶ概念として取扱われるようになる。しかし，歴史的に見れば，それぞれの 論書の著者によって, ニクシェーパの捉え方は様々であり,「いくつかの観点に 基づいてひとつの単語をとらえる」という性質において類似性が認められるナヤ との関係上，ニクシェーパの存在意義そのものに関する議論も交わされることも ある・

また一方で，研究史に目を向けてみると，このニクシェーパという概念につい ての研究が, いわゆる聖典期から論理学期にかけて, 通史的に詳しく研究され尽 くしている，というわけでもない。これまであまり重視されてこなかったといっ ても過言ではない.そこで本稿では，このニクシェーパに関する主な先行研究を 紹介し，論理学期における最も主要なテキストとも言うべきUmāsvāti/Umāsvāmi による Tattvārthādhigamasūtra およびそれに対する自注において，ニクシェーパが どのように定義されたのかを検討した。

\section{3. スポー夕論証における〈順序〉の検証}

斉藤 茜

古代インドに扔いて, 語の本質を追求した結果, 文法学派が到達したのはスポー 夕という概念であった，彼らが語意表示者として提唱したスポー夕は，順序を持 たないもの（akrama）として捉えられる。一方でヴェーダ聖典の教令の解釈に関 連してことばに関する考察を発展させたミーマーンサー学派は, 語意表示者とし て諸音素を上げ，さらにそれが意味理解の起因となるための必須条件のひとつと

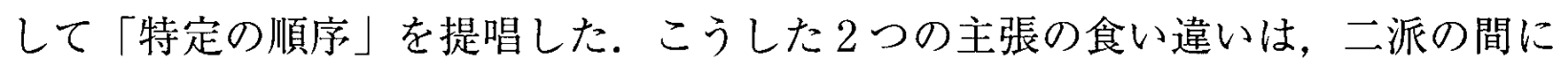
長くに亘る論争を齊すことになる。では文法学派のスポー夕理論において，順序 の概念はどのように取り除かれるのか.これを，文法学派に多くを依拠しつつも 独自の議論を展開した Mandanamiśra の著作 Sphoțasiddhi を検討することで解明を 試みる。本論文では先ず，当該文献の議論展開を追いながら，対論者として挙げ られるミーマーンサー学派の音素論を, Manḍana がどのように斥けるかを検討し, 
両者の立場が交わらない根本的な原因が，〈順序〉という属性の帰属先の違いで あることを明らかにする。その後 Manḍana が提示する意味理解のプロセス（= スポータ開顕のプロセス）を見た上で，それ以上分割できない単一の実体として の語 スポータの妥当性を検討する.

\section{4. 文法と術語: Brohafi および Nyāyamañjarī における Aștāadhyāy $\bar{\imath}$ 批判の特幑}

パーニニ文法学者は文典 $A s t a \bar{a} d h y \bar{a} y \bar{\imath}$ (A) に何らかの技術的問題点が見つかっ た場合，常に詳細な説明（vyākhyāna）を行いその排除に努めてきた。それらの 問題は基本的にパーニニ文法学者の扱うべき課題であったが，Brhatī (B) およ びNyāyamañjarī（NM）という非文法学者による著作にそれらが批判されている 箇所が存在する。前主張としてのヴェーダ批判の文脈に現れるこの批判は, 内容 としては大略パーニニ文法学者の著作, 特にMahābhāsya の部分的な焼き直しに 過ぎない.しかし，それらの議論が B およびNMといった著作に取り上げられ ているという事実はなお一考の価值を有するものである。なぜなら，これらの議 論の存在は, プラクリヤー文献と呼ばれるの A 注釈書群一ここれらはそれ以 前の注釈書とは方法論的／性格的に一線を画する一一か登場する舞台背景を我々 に示し出す可能性を有しているからである。

\section{5. 終末期の看病指針 一初期仏典から一}

\section{小池 清廉}

高齢化の今, 終末期病人, 認知症, 重度の精神又は身体障碍者等の医療・介護 の現場では，ケアする者も，病人自身も，その家族も，生き方死に方に関する倫 理問題に直面している。ケアする者によるケアのあり方, 自身が障碍者になった 場合のケアのされ方について，律，阿含は，以下の指針を示す。

ブッダは病人を見舞い，看病を賞賛した，自殺願望を抱く重患比丘には，長老 比丘は生きよと励ました。看病を放裹されて独り大小便に浸かっていた重病比丘 を, ブッダは自ら助け起こして看護し, 看病は仏法に適うと説き, 看病放亲は律 違反とされた。律は，「いのちある限り看護すべきであり，治るまで待つべきで ある」と説く. 
病比丘看護は比丘の義務であるが, 薬を準備できない, 病状を理解できない, 私欲のために看護する，慈悲心に欠ける，病者の出す污物の除去を嫌う，法を説 いて病人を喜ばせることができないのは, 不適切な看病人とした．臨死状況では， 見舞いにより終末期重病と知れば，病比丘の修行と教説理解を確認し，答えを得 てから記別を与えている (臨死問答).

病者に死を賛美し，自殺を勧めて死を招けば，僧伽追放の最重罪（波羅夷）で ある．重病比丘の自殺願望に応えて自殺を幇助する,死を依頼した病人を殺せば, 波羅夷である。これは「自発的安楽死」の禁止に相当する。長らく看病して来た

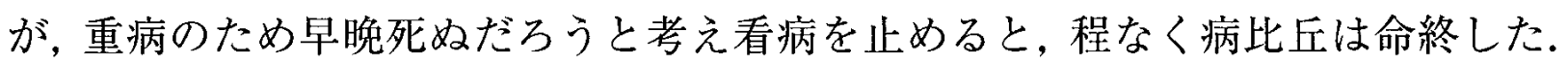
この看病比丘は波羅夷に次ぐ重罪（偷蘭遮）を科せられた。これは現代の「死ぬ に任せる」ことと同等である。

病人療養心得とは，扔互いに会話ができ，看病人の言を聞き，病状を正しく告 げ，食事療法を守り，薬を服用し，忍耐強く適切な療養ができ，終末期の苦痛に 耐え, 看病人に慈悲心で接する等である。これらに反する行為を示す病比丘の看 護は困難であるとするのは，実態の反映であろう。上記指針は，現代のケア場面 に通用する実践倫理といえる。

206. チベット語訳『根本説一切有部律』「薬事」におけるトクパレス写本の問題

八尾 史

チベット語訳『根本説一切有部律』「薬事」において, 諸写本・版本の比較の 結果, トタパレス写本は他の六種の写本・版本（デルゲ版, 北京版, ナルタン版, ロンドン写本, 東京写本, プダク写本）との間に大きな構造上の相違を有するこ とがあきらかになった。

相違は四点である．1．他本にある，過去仏の名を列挙した部分がトクパレス 写本には存在しない，2．トクパレス写本には他本にないウッダーナ（目次）が 一籄所存在する。 3.「薬事」中の「アナヴァタプタ・ガーター」とよばれる偈部 分には四つのウッダーナが置かれているが, その位置がトクパレス写本のみ異な る. 4. 仏の前生譚であるヴィシュヴァンタラ王子の物語が, 他本では二回, 多 少形を変えてたてつづけに語られるのに対し，トクパレス写本では一話のみしか 語られない。それは他本における二番目の物語に，一番目の物語の記述が二箇所 入りこんだ形であり，単純な筆写上の過誤ではありえず，意図的なテクストの改 
編の結果であると考えられる.

これらの相違がどの時点で, どのような原因で生じたものかはいまだ不明であ るものの, トクパレス写本もしくはそれを遡るいづれかの写本の段階において, 意四的に，かつ大幅に「薬事」のテクストを改編しようとするこころみがあった と考えられる。このようなこころみは『根本有部律』全体にわたる可能性がある. チベット語訳『根本有部律』を扱ううえで, トクパレス写本がきわめて注意を要 するヴァージョンであることはたしかである。

\section{7. 説一切有部における対照性一優婆塞となるための要件から一}

石田一裕

本論文は, カシミール有部とガンダーラ有部の傾向について, 優婆塞となるた めの要件の相違から考察を試みたものである.カシミール有部とガンダーラ有部 を比較した場合, 前者が保守的で, 後者が進歩的と指摘されることがあった。こ の指摘の一因となっているのが, 兩有部に抢ける優婆塞となるための要件の相違 である、両者の間にどのような相違があるかというと，カシミール有部は三帰と 五戒によって優婆塞となることができると主張するのに対し，ガンダーラ有部は 三帰のみで優婆塞になれると主張する．従来この相違については，カシミール有 部の厳格な要件が, ガンダーラ有部の要件に緩和されたと理解され, それを根拠 としてカシミール有部が保守的な傾向を, ガンダーラ有部が進歩的な傾向を，そ れぞれ有すると考えられていた，本論文は，しかし，それが誤解に基づくもので あることを『大毘婆沙論』の当該簓所の考察を通して示すものである。『大毘婆 沙論』の考察から導かれるのは, 優婆塞となる用件が「三帰と五戒の厳格な要件」 が「三帰のみの緩和された要件」に移行したということではなく，要件の相違は 経典の理解に基づいて生じたものだということである。優婆塞となる要件の相違 が, 経典の理解と密接に結びついていることは『俱舎論』によっても確認でき, 両テキストの考察から導かれるのは，ガンダーラ有部が経典を重視した保守的な 主張をしており，それと比較するとカシミール有部は進歩的な主張をしていると いうことである、筆者の導いた両有部の傾向は，これまでの指摘と相違するもの かもしれないが, 少なくとも優婆塞となるための要件の相違は, カシミール有部 が進歩的な傾向を，ガンダーラ有部が保守的な傾向を持つことを示している. 
208.『長阿含経』のギルギット写本に含まれる二つの Lohitya-sütra

$$
\text { チェ・ジンギョン（崔 珍景） }
$$

1990 年代の中頃, パキスタンのギルギットから〔根本】説一切有部教団が伝 承した梵文『長阿含経』の樺皮写本が発見された。写本は完全な形で残っていた なら 454 葉よりなる巨大写本であったが，前半部は痛みが激しく，回収されたの は後半部約 250 葉と多数の断片であった．写本の予備的な分析の結果，〔根本〕 説一切有部教団の『長阿含経』が，第 1 編「六経品」全 6 経，第 2 編「双品」9 組のペアー経典よりなる全 18 経，第 3 編「戒藴品」全 23 経の， 3 編 47 経から 構成されることが判明した。この中, 私は, 第 3 篇「戒䅔品」に含まれる第 25 経, さらに第 27 経と第 28 経の計三経典について，ミュンヘン大学のイェンス = ウ ヴェ・ハルトマンと佛教大学の松田和信の指導を受けながら, ミュンヘン大学に 提出予定の学位請求論文の一部として, それら三経典の解読研究を行っている. その中, 第 27 経と第 28 経は写本に現れるウッダーナ（項目, 目次）から判断し て，両方ともLohitya-sūtra の同一タイトルで呼ばれていたことが知られる，パー リ長部の第 12 経（Lohicca-sutta）は，これら二経典の第 28 経の方に対応し，第 27 経はパーリ三蔵にも漢訳『長阿含経』にも対応経典の存しない〔根本〕説一 切有部独自の経典である。今回の発表では, 二つの Lohitya-sūtraの内容と解読研 究の現状を報告し, なぜ同名の二つの経典が同じ『長阿含経』中に存在するのか を考察した。

\section{9. 燃燈佛授記物語の形成と発展}

一『聖燃燈授記大乗経』と他の諸伝承との関係一

松村 淳子

燃燈佛授記物語の単独經典があったことは，『佛本行集經』の記述からも想像 できるが，現存しているのはチベット語聖典カンジュルの中にある『聖燃燈授記 大乗経』だけのようである，かつて，Léon Feer がフランス語訳を出したが，ほ とんど注目されていなかった。筆者は『国際仏教学大学院大学研究紀要』15号 (2011,5)，81-141で，チベット文と英訳を出版し，その中で，まず燃燈佛の誕生・ 成道・教化の物語部分の比較を行い, 『印度学仏教学研究』59 巻 3 号で論じた菩 薩の名前による, 諸本の伝承の分類が内容においても対応していること, 特にチ 
ベット語単独經典は，もっとも発展して整った形を示しており，『佛本行集經』 ならびに『四分律』と非常に近いことを論証したが，本論文ではさらに，授記物 語部分の比較を行い，同様の結果が得られた．特に注目されるのは，ガンダーラ 美術の蓮華の描写と分類した諸本の関係が明らかになったこと，釈迦牟尼の妻の 名前も，3 分類に対応していること，また布髪について，通説となっているよう な泥地を覆うというエピソードが存在しない文献もあり, むしろ布髪は燃燈佛の 足を泥に污れないようにするためではなく，菩薩の発心の堅いことを表現するた めのものであることを論じた。

210. ウパグプタ伝説の諸伝承 一マーラ調伏譚を中心に一

山崎 一穂

本論文ではアショーカ王伝説の一部をなすウパグプタ伝説所収の一挿話マーラ 調伏譚を取り上げ，11 世紀にクシェーメーンドラによって著された仏教説話集 Avadānakalpalatā (Av-klp)，12 世紀にビルマで編纂された宇宙論文献 Lokapaññatti （Loka-p）所収本の源泉資料解明を試みた。比較対照に供したのはDivyāvadāna (Divy), 漢訳『阿育王伝』,『阿育王経』, 『大荘厳論経』,『賢愚経』, 『注維摩詰経』, チベット僧ターラナータの『仏教史』所収の七つの並行話である.

マーラ調伏譚は LÜDERS［1926］の先行研究に基づくと概ね二系統に分類するこ とが可能である，すなわち『大荘厳論経』の梵本である Kumāralāta（二世紀後半） の Kalpanāmanditikā を大幅に借用して著されたDivy，漢訳『阿育王伝』，『阿育王 経』の三本と『大荘厳論経』に代表されるDivy 系統伝本, それ以外の非 Divy 系 統伝本である．Av-klp は Divy 系統に属する．尤もAv-klpにはDivy 系統伝本の 伝える内容の欠落や相違を示す場合もあるが，いずれもクシェーメーンドラの省 略或いは彼による物語の肉付けと見なし得るものである。これに対し Loka-pの 所伝は犬の屍に関する記述が非 Divy 系統のものと一致することから, 非 Divy 系 統の伝本に親近性を示す. Loka-pにはマーラとウパグプタの神通力競争に関す る記述が存するが, これには『賢愚経』,『根本説一切有部律破僧事』における外 道と舎利弗の神通力競争モチーフに並行個所が見られる。従って Loka-p の編者 がこのモチーフに着想を得て，類似のモチーフをマーラ調伏譚に挿入した可能性 が考光られる。 


\section{1.『金光明経』「嬂悔品」一懺悔するのは誰か一}

鈴木 隆泰

筆者はこれまで，『金光明経（Suvarna[-pra-]bhāsottamasūtrendrarāja）』の制作 意図に関して以下の〈仮説〉を提示してきた。

-大乗仏教徒の生き残り策としての経典：『金光明経』に見られる，従来の仏 典では余り一般的ではなかった諸特徵は，仏教に比べてヒンドゥ一の勢力が ますます強くなるグプタ期以降のインドの社会状況の中で，余所ですでに説 かれている様々な教説を集め，仏教の価值や有用性や完備性をアピールする ことで，インド宗教界に生き残ってブッダに由来する法を伝えながら自らの 修行を続けていこうとした，(大乗)仏教徒の生き残り策のあらわれである.

・一貫した編集意図，方針：『金光明経』の制作意図の一つが上記の「試み」 にあるとするならば，多段階に渡る発展を通して『金光明経』制作者の意図 は一貫していた。

-蒐集の理由，意味：『金光明経』は様々な教義や儀礼の雑多な寄せ集めなど ではなく，『金光明経』では様々な教義や儀礼に関する記述・情報を蒐集す ること自体に意味があった。

本稿では『金光明経』の中核をなす章であると見なされてきた第 3 章「驖悔品 (Deśanā-parivarta)」に焦点を当て，「嬂悔品」における㙨悔の重要性や，懺悔の 実践者は誰なのか，そして増広部の増広理由を探ることを通して，〈仮説〉の検 証を続けた。その結果，「仏教が斜陽となる中，仏教の存続に危機感を抱いた一 部の出家者たちは，在家者から経済的支援を得てインド宗教界に踏みとどまり， 仏教の伝承と実践という義務を果たすため,『金光明経』を制作した，彼らは『金 光明経』の価值や有用性や完備性をアピールするため, 適宜『金光明経』を増広 発展させていったが，「価值や有用性のアピール」という彼らの制作意図は，『金 光明経』経題の由来となり『金光明経』制作の中核をなすと考えられてきた「慛 悔品」(増広前の第一部・第二部，その主題は懺悔の実践ではなく，『金光明経』 聞法の勧奨）においても明確に読み取ることができた。そして「懺悔品」の増広 （第三部）に際しては，「『金光明経』の完備性のアピール」のため「仏説たる経 典として,より体裁を整える」ことに主眼が置かれた.」という結論を得たことで， 所期の目的を達成した。 


\section{2. 何故 Mādhyamika は「中観」と翻訳されたのか？}

赤羽 律

中観派という呼称は仏教を少しでも萶ったことのある人ならば誰でも知ってい るといってよいほど広く知られた名称である。しかし，元々サンスクリット語で Mādhyamika と呼ばれ，直訳としては「中」という意味にしかならない名称が， 何故「観」の字を加えられた「中観」という呼称として翻訳されたのかについて は定かではない。本稿で明らかにしようと試みたのは，まさにこの点である。中 観という呼称を学派名称として初めて用いたのは義浄であるとこれまで考えられ てきた.しかしこの呼称そのものは決して義浄が独自に生み出したものではない. 義浄以前に，中国における中観派系統の学派である三論宗の実質的な開祖である 吉蔵が, Nāgārjuna の『中論』を註釈した際に, そのタイトルを『中観論疏』とし, 『中論』を『中観論』と呼んだことに由来すると考えられる。この『中観論』と いう㭔称が 7 世紀半以降，中国を中心に広く知られていたことは明らかであり， インドに渡る以前の義浄が知っていたと十分に考えられる。それ故に，インドに おいて Nāgārjuna の思想に基づく学派として Mādhyamika という呼称を耳にした 義浄の脳裹に, Nāgārjuna の最も重要な論書である『中論』即ち『中観論』とい う名称が浮かび，それを学派名称に転用したとしても何ら不思議はないであろう。 また「観」の字を加えた理由は定かではないが, 吉蔵の『中観論』という名称に 関する注釈に従うならば，『中論』の各章に「観」の字が付けられていることに 基づいたためではないかと推察される。何れにせよ, 義浄以前の 7 世紀に活躍し, インドの仏教事情に詳しい玄然や，630 年代初頭に『般若灯論』の翻訳を行った インド人 Prabhākaramitra といった著名な仏教僧たちが何れも，中観派という呼称 を用いていないことから，恐らくこの用語を学派名称として初めて用いた人物が 義浄であると想定するのが現段階では妥当であろう。

213. アヴァローキタヴラタとカースト制度

西山 亮

釈尊もしくは初期の仏教は，インド社会を現代にいたるまで特徴づけている階 級差別を批判し，バラモン・クシャトリヤ・ヴァイシャ・シュードラという四姓 が平等であることを主張したと伝えられている. その平等論は多くの研究者に 
よって紹介され，そして仏教思想の優れた点として人々に賞賛されてきた。しか L, J. W. de Jong 氏（"Buddhism and the Equality of the Four Castes," 1988）や Donald S. Lopez Jr. 氏（Buddhism \& Science, 2008）などの幾人かの研究者によって, 八世紀前半に活躍したと考えられている中観派の学匠アヴァローキタヴラタの著 書 Prajñapradipa-tīkāo中に, 釈尊が説いた四姓の平等に反するような記述がみ られることが指摘されている，実際そのテキストにおいて異教徒の典籍である Manusmrtiの一節が引用され，その内容はシュードラに対する差別であることが 確認できる。これまでの研究者はみな一様に,このような Manusmrtiの一節をア ヴァローキタヴラタが自説の教証として肯定的に引用し, そして四姓の差別を容 認していると考えているのである。しかし，当該箇所をよく吟味すると，かれは むしろ伝統にのっとり四姓の差別を批判しているように読みとることができるの である。テキストを読み解く際の鍵となるのは「dbri bkol」というあまり用例の 見られないチベットのことばである。

\section{4.『タットヴァ・サングラハ』「外界対象の検討」章に引用される『観所縁論』 の意義}

松岡 寞子

『タットヴァ・サングラハ』「外界対象の検討」章では, 外界対象の存在が不合 理であることと, 認識が所取・能取という二相を欠いていることを根拠として唯 識説が確立されることが説示される．シャーンタラクシタはv.118（TS $\mathrm{TS}_{\mathrm{B}} 2082 ）$ において次のように述べる。

能力が直前の認識にあるとき，所取分に関して〔認識〕対象が確立される $(\mathrm{ab})$.〔しか しながら，所取分に関する認識対象の確立を]我々は真実のものとしては認めない．し たがって〔我々は〕それ（認識対象の確立）を支持しない（cd）.

認識の一部分に認識对象を設定するという $\mathrm{ab}$ 句の見解が『観所縁論』におけ るディグナーガの主張に一致することは『パンジカー』に『観所縁論』を引用す るカマラシーラによって指示される。両師弟はこのディグナーガ説をいかなるも のとして言及しているのか. 西沢史仁氏は，師弟がディグナーガの唯識説をそれ とは異系統の唯識説を奉じる立場から批判しているとみなしている(「カマラシー ラのディグナーガ批判」『インド哲学仏教学研究』3（1995)：21). しかし, 師弟 は認識対象の設定を全面的には否定しておらず，ましてや唯識論師ディグナーガ 
を批判していない.

『パンジカー』，及び『観所縁論釈』等によれば，ディグナーガが『観所縁論』 において認識の所取分に認識対象を設定したのは世俗的真理の観点からであって 究極的真理の観点からではない.そしてこの所取分に認識対象を設定すること, 認識に所取・能取という二相を設けることこそが唯識説における「垢」である。 この「垢」が真実の観点から除去されることにより，最終的に唯識説は「無垢」 (119b': vimala) となる.シャーンタラクシタの見解において, 唯識説はこのよ うに認識の無二性に帰着するのである。

\section{5. 商合性と非錯誤}

小林 久泰

正しい認識手段のひとつ, 知覚を定義する際に, ダルマキールティが『プラマー ナ・ヴィニシュチャヤ』と『ニヤーヤ・ビンドゥ』の中で「非錯誤」(abhrānta) という概念に言及したことは周知の通りである。これはディグナーガの知覚の定 義にはない新たな概念であった。

ヴィニータデーヴァは，ダルマキールティの知覚の定義の中のこの「錯誤して いない」という語をプラマーナの定義「禹合性を持つこと」(avisamvāda) に相 当するものとして理解する。これに対してダルモーッタラはこのようなヴィニー タデーヴァ流の理解を同義語反復となるとして否定する。しかし，問題はダル モーッタラが言うほど単純なものではない.

まず，このような彼の批判の前提には，知覚は正しい認識であるので「斉合性 を持つ」という性質を既に備えているという考えがある.しかし『ニヤーヤ・ビ ンドウ』の簡潔極まりない表現から, 知覚の定義の中の「知覚」という語が「斉 合性を持つこと」を含意していると考えるのは極めて困難であるまた『『ニー ヤ・ビンドゥ』がそれ自体で完結しているひとつの独立作品であることを考える と，その中に正しい認識の定義が提示されていない以上，知覚の定義で提示され る「錯誤していない」という表現が単なる知覚の定義以上の意味を持つ可能性も 十分考えられる.さらに, ダルマキールティ自体,「錯誤していないこと」と「斉 合性を持つこと」を同列に扱っている簓所がある. 従って, ダルモーッタラの批 判をそのまま受け入れるには注意が必要である。 
216. krtakatvānumānaに関するアルチャタ，ダルモーッタラ，ドゥルヴェーカミ シュラの解釈について

ーダルマキールティにおける viparyaye bādhakapramāna の展開一

酒井 真道

諸事物の刹那滅性を証明する推理形式の一つ sattvānumāna（SA）は刹那滅論証 をめぐる以降の思想史に強い影響を与えた。この SA 確立するにあたりダルマ キールティは，所証属性の対概念の領域に論証因が起こることを否定する正しい 認識 viparyaye bādhakapramāna（V-Bp）を用いて，論証因と所証との間の遍充関 係を確定している。このSAの登場により, 論証因を「所作性」とし, 消滅する ことに関する無依存性（vināśam praty anapekșatva；以下「無依存性」）を用いて刹 那滅性を証明する伝統的な推理形式 krtakatvānumāna（KA）は影を潜めたかに見 えるが, 8 世紀以降, KA の解釈に関して思想史は新たな展開を見せる.すなわち, アルチャタはKA の推論式を先師に帰されるV-Bp と見做し，それまでのダルマ キールティ註釈者には見られない解釈を提示する。このアルチャ夕の解釈を継承 する形でダルモーッタラとドゥルヴェーカミシュラはKAにおける遍充関係確定 の方法を論じる，彼らの解釈に従えば，ダルマキールティは，KAにおいて，所 証「刹那滅性」の対概念の領域, すなわち, 非刹那滅なものの領域に,「無依存性」 の対概念, すなわち,「依存性」が起こることを指摘することで,「所作性」と「刹 那滅性」との間の遍充関係を確定している。ダルマキールティはVādanyāya にお いて, 所証属性の対概念の領域に論証因の対概念（hetuviparyaya）が存在するこ とを論証する正しい認識が V-Bpであると述べている。つまり,ダルマキールティ は既に KA を論じる段階で，実質的にはV-Bpの方法を用いて遍充関係の確定を 企てていたと言える.

\section{7. ジュニャーナパーダ著『四支成就法普賢母』*Caturañgasādhana-Samantabhadrī の復元}

菊谷 竜太

ジュニャーナパーダ (Jñānapāda, ca.750-800) は,『秘密集会タントラ』ジュニャー ナパーダ流の祖として知られる一方で「生起・究竟」の二次第及び「瓶・秘密・ 般若智」三灌頂次第の体系化にも大きな役割を果たしたと考えられる．彼の生起 
次第に関する著作としてチベット大蔵経には『普賢成就法』（東北 1855）と『四 支成就法普賢母』（東北 1856）両書が収録される。サンクリット原典は現在断片 が回収されるに留まっている．前者はリンチェンサンポ（Rin chen bzan po, 9581054)，後者はスムリティジュニャーナキールティ（Smrtijñānakīrti）によって訳 出された。このうち『四支成就法普賢母』は偈の順序が著しく混乱し，ところど ころ欠損部分も見出される，そのため内容的に極めて類似する両書を同一原典か らの異訳と看做すかどうかはチベットで古来より議論されてきた. 大蔵経には『普 賢成就法』・『四支成就法普賢母』雨書に対してあわせて 4 種類の注䣋が残されて いる。筆者の調查によれば，ヴイタパーダ（Vitapāda ca. 920-970 C.E.）の『四支 成就法普賢母注』（東北 1872）中に『四支成就法普賢母』スムリティ訳のほぼ全 文が収録されていることが明らかになった。したがってヴィタパーダ注より『四 支成就法普賢母』における偈の再配列および久損部分を補うことが可能である. さらに上記の注釈文献を用いて『普賢成就法』・『四支成就法普賢母』両書を対照 したところ,伝達者の系統にあわせていくつかの異読が見出された，すなわち『普 賢成就法』はタガナ・ラトナーカラシャーンティを経てリンチェンサンポに続く 系統であり，一方『四支成就法普賢母』はヴィタパーダを経てッァラナ・イェー シェーゲンツェン（Tsalana Ye śes rgyal mtshan）に続く系統だということが出来る.

\section{8. サンスクリット写本 NAK 3/716（=NGMPPA48/11）について}

\section{一Samvarodayatantra の註釈書 Sadāmnāyānusārin̄ī}

本稿は，まず Nepal National Archives に保管されているサンスクリット写本 NAK 3/716（=NGMPP A48/11）に見られる興味深い事柄について考察した。こ の三四葉から構成されている写本には三種類の文献の写本断片が含まれるＳSadāmnāyānusārin̄i (SĀA) が三二葉, Samvarodaytantra（SUT）が一葉, そして医学 書であるSuśrutasamhitāa（SŚS）が一葉（表のみ）である.SĀA 写本の特筆すべ き特徵を二点挙げ, 考察し, さらにSĀA の根本タントラであるSUT おょび SŚS の写本断片が混在したのかについて推論した.

続いて，SĀA について特徽や内容を紹介した。写本の写真が不明瞭であった ために仮題であった SAAAの文献名がその冒頭偈に記されていることをつきとめ た。さらに SAAA と文章構造が似ている RatnarakșitaのPadminī との関係がそれら 
類似性だけでなく，SAA がPadminīの縮約であると言う可能性について例文を 挙げて提示した．最後に数多くの顕密両文献を駆使して SUT の解説をする SAA が引用する顥教文献・中観派 Āryadeva の Catuhśataka 第 12 章第 18 偈を挙げた. 本偈はこれまでサンスクリット原文が回収されていなかったが，この発見によっ て一偈追加されたことになる。

\section{Tāranātha の dBu ma theg mchog に説かれる二諦説}

望月 海慧

チベット仏教のチョナン派の Tāranātha Kun dga' snying po（1575-1635）による Theg mchog shin tu rgyas pa'i dbu ma chen po rnam par nges pa (dBu ma theg mchog) の第 7 章は，「二諦の決択」というタイトルで二諦説が論じられている。本章の 特徴をまとめると，次のようになる。

1. Tāranātha の二諦説は, Maitreya の Mahāyānasūtrālaṃkāra と Madhyāntavibhāga, そして Nāgārjuna の Mūlamadhyamakakārikāを引用して議論がなされている。ただ し，その度合いは Maitreyaのテキストが中心となっている。

2. 二諦説は三性説に基づいて解釈されており，円成実性である勝義諦は法界・ 真如・如来蔵などの語により説明されている、これらのことから, 彼の立場は同 じチョナン派の Dol po pa Shes rab rgyal mtshan（1292-1361）の他空説の立場を継 承するものである.

3. Täranātha のテキストにはDol po paへの直接の言及は見られないものの，そ の注釈書には彼のbDen gnyis gsal ba'i nyi maの引用も見られ, 同論と重なる記述 を多数見ることができる、Vasubandhuに㷌される『般若経注』も同じように引 用されることからも，本章は同論に基づいて著された可能性がある。

\section{0. 立正大学図書館所蔵河口慧海旧蔵文献}

庄司 史生

本稿は，2009 年に立正大学図書館から新たに発見された河口慧海旧蔵文献の 紹介を目的とする。特に梵巴蔵にわたる将来文献の一覧と, Samvarodaya-tantra の翻刻を掲載する。彼の旧蔵文献には梵文写本 2 点, 巴利語写本 3 点, 西蔵文献 約 30 点から成る将来文献の他に, 洋装本, 和装本の類も含まれている。それら 
文献資料に関する調查報告の結果は 2012 年に公表される予定である.

ところで，立正大学に河口慧海旧蔵文献が所蔵されていたことは，従来見過ご されてきたといえる。実際には，彼の甥である河口正によって 1961 年に春秋社 より出版された『河口慧海』の中に, 河口慧海の旧蔵書の所蔵先として, 同大学 の名が挙げられていた，筆者は偶然にも，同大学図書館未整理資料の調査途中に 河口旧蔵文献を見出すこととなった。その中には，本稿にて翻刻を示したSamvarodaya-tantra（1 葉のみ）とGanda-vyūha（完本）の二種の梵文写本が含まれて いた，本稿では特に取り上げていないが，Ganda-vyūhaは1934 年から泉芳璟と 鈴木大拙によって出版される同梵本校訂本の底本となった写本そのものであるこ とが判明している，校訂本では同写本が東京大学所蔵と説明されているものの, 実際には所在不明となっていたものである.

立正大学に所蔵されていた河口旧蔵文献は彼の死後, 同大学内に一括譲渡され たものである。つまり，それら旧蔵文献は最後まで彼の手元にあった資料という ことになる。

河口旧蔵文献が立正大学へ譲渡されるに至る経緯の詳細は不明な点が多い。た だし，当時同大学学長であった石橋湛山，同教授三枝博音，同 J.R. ブリンクリー らがそこに関わっていたことが調查の結果明らかとなっている.

本稿では，河口慧海旧蔵文献の全体像を示したにすぎない。各資料に対する研 究は今後の課題である.

\section{Tel-loñāni 一バルア仏教徒の婚姻儀礼一}

BARUA Titu Kumar

Tel-loñāni はバングラデシュのバルア仏教徒が結婚式当日に式前に家庭で行な う儀礼で,「頭に油を注ぐこと」を意味するチッタゴン方言に由来する。本論では, この儀礼の次第と, 儀礼の随所に込められた象徵的な意味を取り上げた.

まず僧侣に日取りを相談するのだが，バルアにとっては川の満潮時がめでたい 時である，儀礼に際してはドゥルヴァ草やグアヴァなどを準備するが，それらに は,「成就」や「繁栄」などの意味が込められている。

Tel-loñāni 儀礼は新郎新婦それぞれの家で一連の儀式を 5 回行う。竹と布で仕 切られた空間にカップルが座り, 列席者が一人ずつ 5 回ドゥルヴァ草で二人の額 に触れる，その後全員の手を添えて同じことをする。これらには，「一人から結 
び合いへ」，「調和」の意味があるとされる。二人が座る敷物は，一回の儀式が終 わるごとに剥がして摇すられるが, 浄化儀礼で二人の体から落ちた穢れがついた ために敷物をきれいにすることを含意している。

儀礼の終盤には，母親と親戚の女性が二人の頬と額にターメリックをつけ，そ れを自分のサリーの端で拭う。これには，子供に別れを告げることが象徵されて いる，そして最後には，マスタードの種と油が清水とともに二人の頭頂に塗られ る。バルア仏教徒はマスタードは風邪の予防, 清水は浄化と長寿をもたらすと信 じている。

このように, Tel-loñāni 儀礼は, 主たる結婚式に臨む前に新郎新婦の心身を浄 化するために行なわれるが，そこで用いられる物や種々の所作には，長寿，繁栄 など，二人の新生活への願いが达められている．また，この儀礼には僧侶は参加 せず家族や親族が関わるのだが，親子としての別れの後に，新たな家庭を築く二 人を親族が今後も支えていくという, 通過儀礼としての特徵が色濃く映し出され ている.

\section{2.『仏説十二門経』『仏説解十二門経』とそれらにおける道安の「序」との対応 について}

洪 鴻栄

金剛寺の書写文献・安世高訳『仏説十二門経』『仏説解十二門経』は，1999年 に発見されて以来ようやく十年を経た。そその内容に対する研究は，いままで，イ タリアの学者 Stefano ZACCHETTI の幾つかの論文しかないのが現状である.

ZACCHETTI 氏は，この二つの写本について，安世高の著作としてはっきりと断 定はできないが，ほぼ彼に属するものであると位置づけた。また，それに関して， なお幾つかの問題が残るものの, 安世高以外の著者のものとして考えるのが難し い点が多いとも指摘している，氏の論証では，これらの写本は『仏説十二門経』 『仏説解十二門経』, そして『仏説十二門経』に対する「解説」との三つの部分に 分けられ，さらに『仏説十二門経』『仏説解十二門経』のそれぞれは，道安のい う『大十二門経』『小十二門経』に相当するという結論に至った。

本稿では，氏の論証は新たな困難を引き起こすのではないかと指摘し，そして 写本に扔ける氏の三つの分け方を検討した結果，『仏説十二門経』『仏説解十二門 経』との二つの区分において十分あり得るため，新たに『仏説十二門経』に対す 
る「解説」という第三区分を設定する必要はない。また,『仏説十二門経』は『大 十二門経』に，『仏説解十二門経』は『小十二門経』に対応するのではなく，そ の反対，『仏説十二門経』は『小十二門経』に，『仏説解十二門経』は『大十二門 経』に対応するという方が, 正確なのではないかと筆者は指摘したい。

\section{3. 東密における『秋摩訶衍論』の解釈の一考察 一信証を中心に一}

橋本 文子

真言宗開祖である空海（774-835）によって大成された十住心思想とは，『大日 経』「住心品」の心続生段を根拠に, 菩提心の展開の階梯を十筒の教判論として 整備された思想体系であり，真言教学の根幹をなすものである。この思想の中で 第八住心に配釈された天台宗側からの反論が提示された．特に台密の大成者とさ れる安然（841-889?）の『真言宗教時義』が痛烈な論駁を行っている．この論書 により，空海の十住心思想を建立する際，いくつかの経論解釈には不明瞭な点が あることを如害に浮き上がらせた。本稿は十住心批判の論駁書『十住遮難抄』の 後半部で取り上げられている『秘蔵宝福』の経論解釈の根底に, 空海が『釈摩訶 衍論』を援用していることに『教時問答』が着眼し批判したことへの論駁を問題 提起の基点とする，信証と時を同じく光明山寺の実範（？-1144）『大経要義鈔』 がこの問題について論駁を施しているが，『釈論』が如何に東密側でより具体的 に論理面で受容されるに至ったか，西院流の祖である仁和寺の信証（1086-1142） が『大昆盧遮那経住心鈔』の中で論駁を施している。『大日経疏』を基底にした 彼の論及を概観しつつ，実範の論駁と対比して試論を述べたい。 